NBSIR 73.294

\title{
Cost Sharing as an Incentive to Attain the Objectives of Shoreline Protection
}

Harold E. Marshall

Technical Analysis Division Institute for Applied Technology National Bureau of Standards

Washington. D. C. 20234

December, 1973

Final Report

$=Q C$

100

.1156

\#73-294

1973

C. 2

\section{ed for}

эnter for Economic Studies ite for Water Resources of Engineers tment of the Army 

COST SHARING AS AN INCENTIVE TO

ATTAIN THE OBJECTIVES OF SHORELINE PROTECTION

Harold E. Marshall

Technical Analysis Division Institute for Applied Technology National Bureau of Standards Washington, D. C. 20234

December, 1973

Final Report

Prepared for

The Center for Economic Studies Institute for Water Resources

Corps of Engineers

Department of the Army

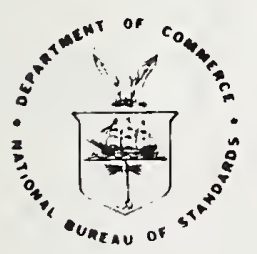

U. S. DEPARTMENT OF COMMERCE, Frederick B. Dent, Secretary 

Current rules for sharing the costs of shoreline protection between Federal and nonfederal interests have been criticized for being inefficient, inequitable, inconsistent among programs, difficult to understand and administer, and unsuccessful in encouraging local interests to participate in projects with the Federal government. This report is an attempt to provide the Army Corps of Engineers (Corps) with an evaluation of existing and alternative cost-sharing rules for shoreline protection with respect to efficiency, equity, and administrative feasibility.

Cost sharing is evaluated in terms of its incentive effects on local interests. Because local interests are primarily concerned with benefits which accrue in their geographical area, they will not necessarily choose the combination of techniques or the scale of shoreline protection that is optimal from the national viewpoint. The major problem examined in this study, then, is to determine cost-sharing rules that will induce local interests to select project designs that are optimal from the national as well as local viewpoints, where both national economic development and enhancement of environmental quality are considered to be objectives.

Existing cost-sharing rules are described under three corps shoreline protection programs: hurricane, tidal, and Great Lakes flood protection; emergency flood and coastal storm protection; and beach erosion control. Examination of cost-sharing rules, statistics of actual cost shares imposed, and theoretical considerations show that existing rules will not induce local interests to choose nationally efficient projects. The present cost-sharing structure tends to encourage more costly techniques of production, e.g., engineering rather than management techniques, and overbuilt projects in terms of the efficient scale.

Two alternative sets of cost-sharing rules, those being proposed in legislation, and those recommended in this report, were also compared. The proposed rules call for either making heretofore ineligible private property now eligible for cost sharing, or an increase in the percentage local cost share for beach erosion control. Adopting this proposed legislation would probably encourage local interests to seek more and larger projects that are nationally inefficient. Rules recommended in this study, to be listed below, are justified on the basis of efficiency, equity, and administrative feasibility. Implementation of the recommended rules will probably result in higher local percentage cost shares on average per shoreline protection project, a shift of local demand away from engineering techniques in favor of management techniques, and more protection benefits per national dollar expended. Futhermore, local interests and the general taxpayer will be treated more fairly in that the costs of shoreline protection would be more closely associated with the beneficiaries.

The specific recommendations of the study are:

(1) The Association Rule, which requires local beneficiaries of shoreline protection to share in all of the costs of a project purpose in the proportion that local benefits bear to national benefits at the margin, should be applied to the beach erosion control, hurricane protection, and emergency protection programs. A second-best solution, in the event that a new flexible-rate rule is not acceptable, is to retain the existing rule for beach erosion control and to raise local cost shares to a flat $50 \%$ for the other two programs.

(2) All techniques, management and engineering, should be subject to the same percentage cost-sharing rule. This means that the corps might have to acquire new authority to plan for and/or cost share techniques such as insurance, zoning, building codes and standards, and land use planning.

(3) All categories of project costs, including construction, lands, easements, rights-of-way, operation and maintainance, and relocation and alteration of utilities should have the same percentage cost share applied to them.

(4) Federal cost sharing should be used as an incentive to encourage nonfederal interests to comply with certain minimum land use requirements that would provide shoreline protection benefits.

Some additional research that might be of value in evaluating alternative cost-sharing rules for shoreline protection was identified in preparation of this report. An essential type of information needed for determining cost-sharing rules is to whom and in what amounts benefits accrue from shoreline protection projects. A second area of research is the description of legal and other institutional barriers 
that might prohibit the corps from implementing management techniques. A third research area is the examination of the costs of management techniques for shoreline protection. A fourth topic is the evaluation of future legislation to be proposed on cost sharing in terms of the criteria presented in this report, with estimates of Federal and local costs for alternative cost-sharing rules. Finally, a research task that would help the purchaser and owner of shoreline property is to classify coastal areas by degree of susceptibility to shoreline damages and to make this information available to the public. 
This study was sponsored by the Institute for Water Resources, U.S. Department of the Army, Corps of Engineers. This research is intended to be useful both to the Corps of Engineers in relating cost sharing to the objectives of shoreline protection and to others who are interested in shoreline protection but have no familiarity with alternatives available to them under corps programs.

The author wishes to thank Dr. V. I. Broussalian for his valuable technical review and the other reviewers in the Technical Analysis Division of the National Bureau of Standards for their comments on this study. The author also wishes to acknowledge the many persons from the Corps of Engineers who patiently explained to him the techniques of erosion control and some of the intricacies of cost sharing for shoreline protection. The responsibility of all errors and shortcomings in the paper, however, rests with the author. 
EXECUTIVE SUMMARY

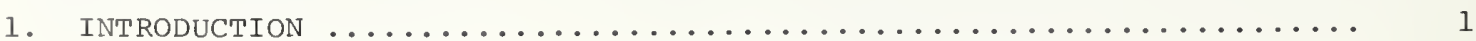

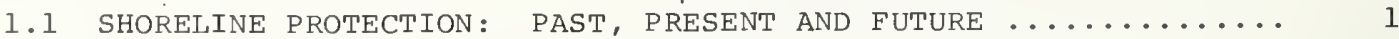

1.2 FEDERAL-LOCAL COST SHARING: PROBLEMS AND INCENTIVES..........

1.3 COVERAge AND STRUCTURE OF THE REPORT ..................... 5

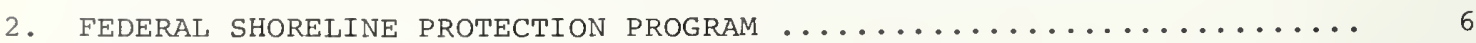

2.1 GENERAL OBJECTIVES OF SHORELINE PROTECTION ............... 6

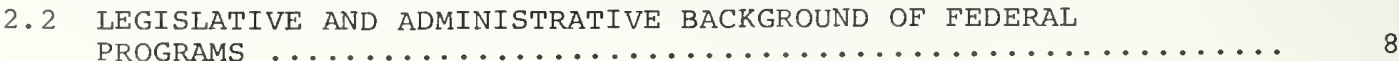

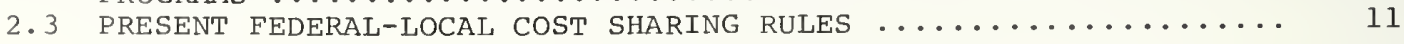

2.3.1 HURRICANE, TIDAL, AND GREAT LAKES FLOOD PROTECTION .... 11

2.3.2 EMERGENCY FLOOD AND COASTAL STORM PROTECTION ........... 12

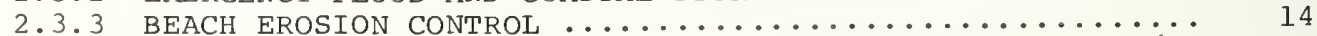

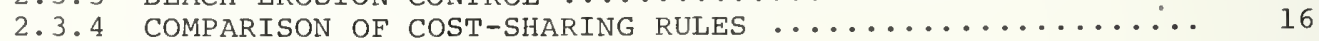

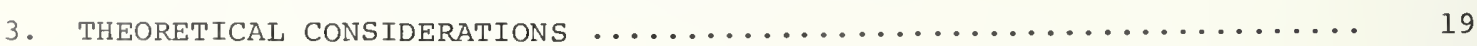

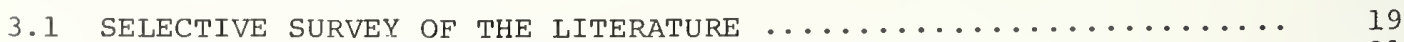

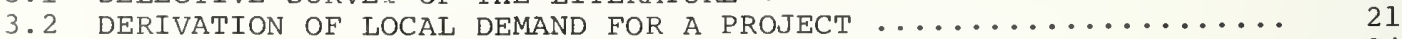

3.3 NECESSARY CONDITIONS FOR EFFICIENCY AND OPTIMALITY .........

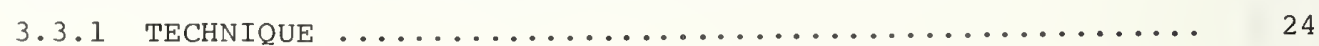

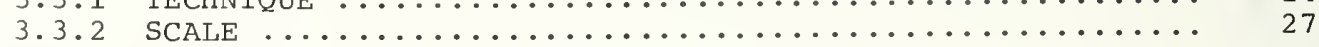

4. DESCRIPTION OF ACTUAL PERCENTAGE COST SHARES AND THEIR

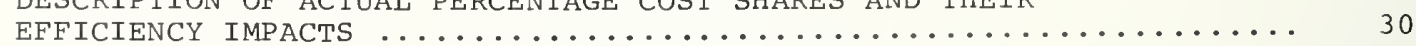

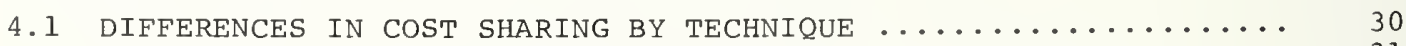

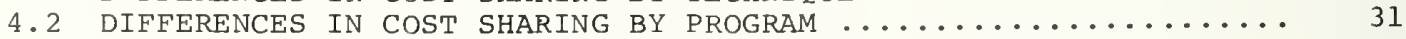

5. EVALUATION OF ALTERNATIVE COST-SHARING RULES WITH RESPECT TO

CRITERIA OF EFFICIENCY, EQUITY, AND ADMINISTRATIVE

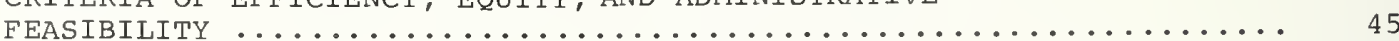

5.1 ALTERNATIVES TO EXISTING COST-SHARING RULES ................. 45

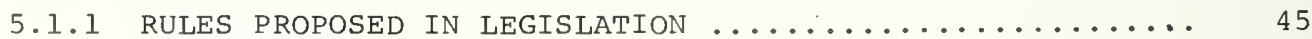

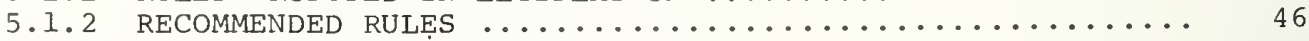

5.2 EVAluation of Existing AND ALternative RULES .............. 46

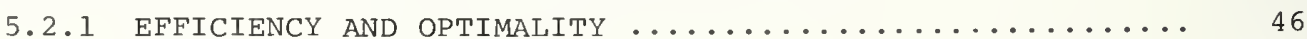

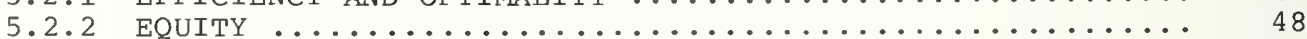

5.2.3 ADMINISTRATIVE FEASIBILITY ........................ 49

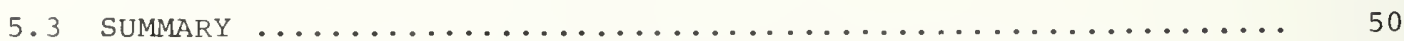

6. SUMMARY, RECOMMENDATIONS, AND SUGGESTIONS FOR FURTHER RESEARCH .... 51

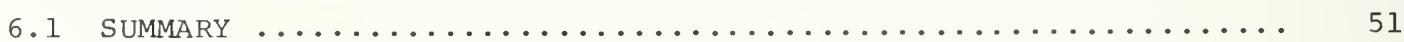

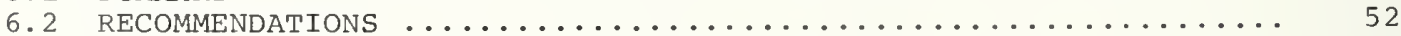

6.3 SUGGESTIONS FOR FURTHER RESEARCH ........................ 53

APPENDIX A: ALTERNATIVE TECHNIQUES FOR SHORELINE PROTECTION ......... 55

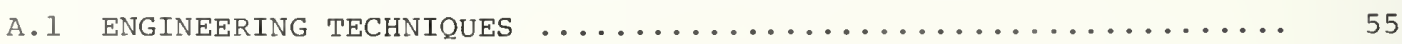

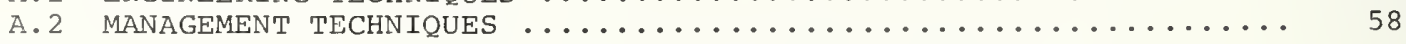

APPENDIX B: BEACH EROSION CONTROL COST-SHARING DISTRIBUTION BY PERCENTAGE OF COSTS SHARED BY LOCAL INTERESTS ........... 60

APPENDIX C: STATE COST SHARING IN SHORELINE PROTECTION PROJECTS ..... 60

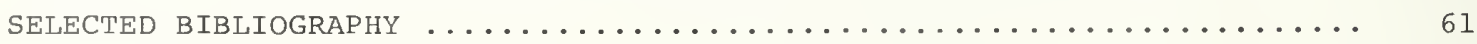


2.1 Maximum Federal Percentage cost Shares for Shoreline Protection by the Corps in Nonfederal Shore Areas .................... 13

2.2 Maximum Federal Percentage Cost Shares for the Corps Beach Erosion Control Program by Ownership and Use ................ 15

4.1 Authorized and Completed Beach Erosion Control Projects ........ 32

4.2 Authorized and Underway Beach Erosion Control Projects ........ 33

4.3 Authorized But Not Yet Started Beach Erosion Control Projects .... 34

4.4 Authorized and Completed Multiple-Purpose Projects Which Include

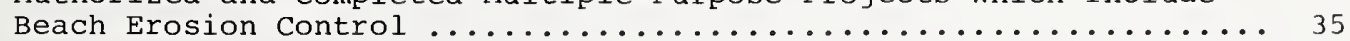

4.5 Authorized and Underway Multiple-Purpose Projects Which Include

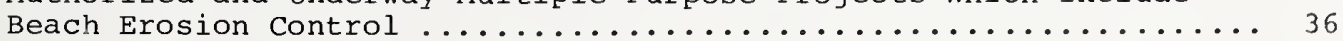

4. 6 Authorized But Not Yet Started Multiple-Purpose Projects Which

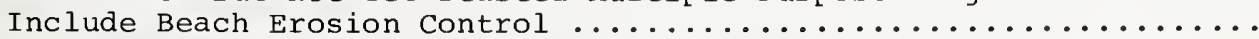

4.7 Percentage Cost Shares for Multiple-Purpose Projects for Hurricane Flood Protection and Beach Erosion Control by state ........... 38

4.8 Percentage Cost Shares for Each Erosion Control by State ....... 39

4.9 Authorized Beach Erosion Control Projects As of June 30, 1968 ... 41

4.10 Shoreline Protection Projects Restored Under P.L. $84-99 \ldots \ldots$

4.11 Apportionment of Cost for Typical Section of New York State Beach.. 43

5.1 Evaluation of Cost-sharing Rules ......................

LIST OF FIGURES

Figure

3.1 Indifference Curves and Budget constraints $\ldots \ldots \ldots \ldots$

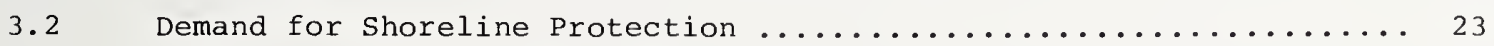

3.3 Cost Share for Efficient Technique (s) $\ldots \ldots \ldots \ldots$

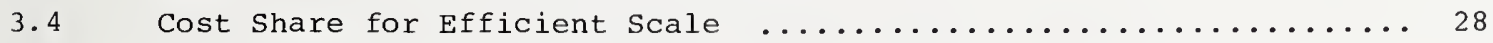


, 
This study attempts to provide the Army Corps of Engineers (Corps) with an objective evaluation of existing and alternative cost-sharing arrangements for its shoreline protection program and to suggest appropriate policy changes. The shoreline protection program is examined in relation to the objective of national economic development as well as the objective of enhancement of environmental quality. Alternative cost-sharing rules are evaluated with respect to efficiency, equity, and administrative feasibility. The incentive effects of cost sharing are emphasized. Although the focus of this report is on cost sharing for shoreline protection, the principles and techniques employed are likely to be of general applicability in evaluating cost sharing for any Federal-local program.

\subsection{Shoreline Protection: Past, Present, and Future}

Man's concern with beach erosion is very recent in geologic time. Prior to World War I, the few people who inhabited the shorelines were fishermen or sailors who respected the natural erosion process of the sea. Harbors were usually landlocked or far up estuaries, thereby protected from the ravages of high waves and tides. Natural dunes and barrier islands protected backshore areas from the encroaching sea.

The concern over shoreline erosion became widespread only after man settled upon and developed the shoreline. The following excerpt from the National Shoreline Study explains why beach erosion suddenly became of national interest.

The technical revolution brought trains, the automobile gasoline-powered pleasure boats, large ships with deep drafts, and the new leisure. Coupled with the population explosion, these developments resulted in hordes of people descending onto the shore.

Dunes were destroyed to make way for hotels, boardwalks, roads, and houses. Breakwaters and jetties were built to aid large and small craft to harbor. In nearly every instance, these harbor structures interrupted the alongshore movement of sand and starved adjacent downdrift beaches.

The rivers were dammed to provide the expanding population and industry with hydroelectric power, water supplies and flood control. These dams have essentially stopped the supply of sand previously reaching the beaches from large parts of the major river basins.

In may places, dunes were bulldozed away merely to provide picture window views of the ocean. ${ }^{1}$

With man's interest in protecting the shoreline came government support of beach erosion control. Federal planning and monetary assistance have been substantial. The Corps of Engineers has cooperated with and shared the costs with nonfederal interests for the construction of 61 beach projects protecting 110 miles of shore. The Federal government has contributed $\$ 28$ million to a total construction bill of $\$ 45$ million for these projects.

Seventeen projects covering a distance of 171 miles of shore have been authorized and are underway. The Federal cost share of these projects is $\$ 279$ million of total estimated construction costs of $\$ 423$ million. Six of the projects underway and 4 of the completed projects provide hurricane protection. Forty-three additional projects, protecting about 300 miles, have been authorized but not yet started. ${ }^{2}$

Past and current protection programs rank relatively small, however, in comparison to those that have been identified as necessary to combat today's widespread and expensive erosion. The National Shoreline Study shows that the United States has 84,240 miles of shoreline. Significant erosion is occuring along 20,500 miles (24\%) of our coasts, although protection appears economically justifiable (i.e., benefits exceed costs of protection) for only 2,700 miles $(.03 \%) .{ }^{4}$ The estimated costs

${ }^{1}$ U.S. Department of the Army, Corps of Engineers, Shore Protection Guidelines, A Part of the National Shoreline Study (Washington, D.C.: U.S. Army Corps of Engineers, 1971), P. 9.

${ }^{2}$ U.S. Department of the Army, Corps of Engineers, Report on the National Shoreline Study, A Part of the National Shoreline Study (Washington, D.C.: U.S. Army Corps of Engineers, 1971), p. 37 . Is lands.

${ }^{3}$ This includes shorelines around the Great Lakes, Puerto Rico, and the Virgin

${ }^{4}$ U.S. Department of the Army, Corps of Engineers, Report on the National Shoreline Study, p. 18 . 
of measures to protect these 2,700 miles is $\$ 1.8$ billion plus $\$ 73$ million for beach nourishment on an average annual basis. 1

The uncertainty and diversity of shore ownership further complicate the shore erosion problem. Excluding Alaska from consideration, the Federal government owns 3,900 miles ( $11 \%$ ) of our shoreline, state and local governments 4,600 miles (12\%), private interests 25,800 miles (70\%), and title is uncertain for the remaining 2,600 miles (7\%). The Federal government owns 41,400 miles or $88 \%$ of the Alaskan shoreline, which includes 47,400 miles. ${ }^{2}$

It is reasonable to expect that the degree of Federal cost sharing influences the willingness of local interests to support the shoreline protection program (to be demonstrated in detail in section.3.2). It is also reasonable to expect, given the current Administration's efforts to reduce Federal spending, ${ }^{3}$ that the legislative and executive departments of the Federal government are unlikely to embark on such expensive and ambitious programs as outlined above, especially with a relatively high Federal cost sharing policy. Thus to provide comprehensive protection from shoreline erosion, alternative approaches to protection may have to be considered.

Cost-sharing rules contribute to a loss in economic welfare when they induce local interests to seek a type of shoreline protection that is optimal from their standpoint, but not necessarily from the nation's. For example, if local interests must pick between a beach erosion project or a larger one that incorporates hurricane protection, they may pick the hurricane project primarily because it requires a smaller local cost share in percentage terms, and possibly even a smaller cost share in absolute terms, even though the beach erosion project might be the optimal one from the national viewpoint. Or, if local interests could protect a shoreline area either by relocating people along the shore or by building engineering structures, they may pick the latter simply because that is the technique for which they can receive Federal aid, even though it might not be the optimal technique from the national viewpoint.

Thus the problem of cost sharing addressed in this paper is how to design a cost sharing system that provides a set of incentives which will induce local interests to ask for and make commitments to those shoreline protection projects that are optimal for the nation as well as for themselves.

\subsection{Federa1-Local Cost Sharing: Problems and Incentives}

The Federal government shares the cost of water, highway, airport, educational, and other facilities with state and local governments. In most cases, Federal legislation dictates how costs will be shared by providing specific cost-sharing rules. In the case of hurricane protection the costs are shared according to the rule that not more than $70 \%$ of construction costs can be borne by Federal interests (in this case the Corps), and at least $30 \%$ of these same costs must be borne by nonfederal interests. ${ }^{4}$

Determining absolute cost shares is more complicated when a project is multiplepurpose (e.g., beach erosion control and hurricane protection are provided jointly), and when the multiple purposes are governed by different cost-sharing rules. Costs attributable to each purpose must be separated out of the total project costs so that cost shares can be determined for each purpose. The process of apportioning total project costs among the multiple purposes is called cost allocation. This procedure is discussed in this report only in so far as it affects cost sharing. 5

${ }^{I}$ Ibid., p. 25.
${ }^{2}$ Ibid., p. 30.

${ }^{3}$ Note that President Nixon vetoed the 1972 Omnibus Rivers and Harbors and Flood Control Bill.

${ }^{4} \mathrm{~A}$ complete description of present cost-sharing rules for shoreline protection is given in section 2.3.

${ }^{5}$ For a detailed description of cost allocation in water projects, see Harold E. Marshall and Vartkes I. Broussalian, Federal Cost-Sharing Policies for Water Resources, National Bureau of Standards Report to the National Water Commission, PB-208-304 (Springfield, Va.: National Technical Information Service, 1972), pp. 28-34. 
The major issue in cost sharing for shoreline protection is often thought to be an inadequacy of the Federal cost share to promote the desired shoreline protection. Since it seems reasonable to expect that higher Federal cost shares (lower local cost shares) would induce local interests to request and support more projects, the implication is that more Federal money is needed to encourage more protective structures. However, since two-thirds of the shoreline suffering critical erosion, where benefits exceed the costs of protection, is held privately, I Federal cost sharing under existing legislation is perforce limited. Local interests have simply not been willing to absorb much of the costs of protection.

Representative Vanik, in a statement supporting a bill on Federal aid for shoreline protection, describes the plight of some of his constituencies in Lake County, ohio, as follows:

... and under current legislation the private land owner along the shore

is helpless. Insurance companies have no provisions for covering loss

of a home or land due to gradual erosion; they are not permitted to

deduct Federal income tax losses resulting from gradual erosion;

and, so far, no Federal aid has been available to help them save

their land. While some 120 Federally assisted beach protection

projects have been constructed or are pending, these have been almost

exclusively for the protection of parks and recreation areas--not

for the protection of communities and their residents. Adequate

protection is beyond the means of local citizens, citizen groups

and their individual cities and counties. In most cases the

various states have also failed to provide help--and their

communities need Federal help. HR 13689 permits Federal assistance

for imperiled homeowners. The enactment of this legislation is

desperately needed. ${ }^{2}$

Here again the cost sharing problem in shoreline protection is perceived to be simply one of insufficient Federal funding.

From a broader perspective, however, the problem of shoreline protection may be viewed as one of protection from injury and damages from erosion forces, rather than simply the protection of the shoreline. Hence, we can regard cost sharing not solely as a tool to induce local interests to accept more structures, but as a general incentive to encourage local interests to consider a variety of engineering and management techniques for the most efficient and equitable solution to the general problem of shoreline protection. This broader perspective is the one adopted in this paper.

The problem is what cost-sharing rules encourage optimal shoreline protection, where protection is defined broadly to include management as well as engineering techniques. This report therefore examines the impact of cost sharing on local incentives with respect to techniques of protection, mix of project purposes (e.g., beach erosion versus hurricane protection), and size of the projects. For this purpose it is necessary to examine, first, what techniques for protection are available, and second, how a shoreline protection project is conceived, planned, and authorized for construction through the Corps programs. ${ }^{3}$

${ }^{1}$ U.S. Congress, House, Committee on Public works, projects proposed for Inclusion in Omnibus River and Harbor and Flood Control Legislation--1972, Joint Hearings, before a subcomittee on Rivers and Harbors and on Flood Control and Internal Development, House of Representatives, 92d Cong., 2d sess., 1972, p. 81.

${ }^{2}$ U.S. Congress, Senate, Committee on Public Works, Omnibus Water Resources Authorizations--1972, Hearings, before a subcommittee on Flood Control--Rivers and Harbors, Senate, 92d Cong., 2d sess. , 1972, p. 576.

${ }^{3}$ For a more detailed description of the Corps planning process, see U.S. Department of the Army, Corps of Engineers, Shore Protection Program (Washington, D. C.: U.S. Army Corps of Engineers, 1970), pp. 5-10. 
Private and public groups have two general kinds of techniques that they can use to protect their beaches; these are engineering techniques and management techniques. (See Appendix A for a detailed discussion of these techniques.) Engineering techniques include jetties, seawalls, breakwaters, groins; vegetative sand cover, dune construction, and other structures that deal with the physical interaction of the shoreline and the sea. Management techniques include zoning, building codes, ordinances, insurance requirements, condemnation, permits, and other government devices that can be used to influence people in their use of the shore. Any of these techniques can be used individually or in combination with others.

The type of technique used to achieve shoreline protection is relevant to this study of cost sharing incentives for two reasons. First, if local cost sharing requirements were to differ among techniques, this might induce local interests to choose techniques on the basis of minimum cost sharing requirements rather than on the basis of cost effectiveness. Second, there may not be any Federal authority for implementing or for cost sharing some of the techniques, especially the management techniques, thereby biasing local and Federal interests against any such alternatives for which there is no precedent.

Recognition of the link between man's use of the shoreline and the damages from shoreline erosion will have an effect on the techniques chosen by government to reduce erosion damages. As scientist Robert Dolan has very clearly pointed out, "...beach erosion is a natural proces, ...., and becomes a serious problem only when man's

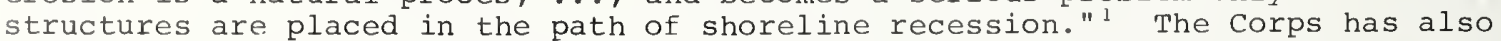
recognized the challenge of new techniques for future shoreline protection as indicated by General Koisch in the following excerpt from a statement to congress:

Land use and development are inseparable from erosion control. In many cases, natural erosion should be permitted to continue. In such cases, zoning or other management regulation is necessary to preclude development that might be damaged. ${ }^{2}$

Given that the National Shoreline Study has outlined shoreline erosion as being a widespread problem, and given that government and private resources are limited in terms of meeting competing demands on them, from water and other programs, then the evaluation of cost sharing as an incentive to local acceptance and support of engineering and management techniques becomes a very important task.

There is a general procedure for planning and developing a beach erosion project. Local individuals or groups concerned about shoreline erosion initially must make a request for help. They may go directly to a corps District Engineer or to nonfederal agencies that specialize in shore management. If, after discussions with the District Engineer, a project appears eligible for Federal assistance under the small project program or under the program for investigating erosion caused by Federal navigation works, the secretary of the Army can authorize a beach erosion study. If the study shows that the project is economically justified, i.e., benefits exceed the costs, and if local groups provide assurances of willingness to pay their required cost share, the secretary of the Army can authorize the project and allocate funds for it from civil works appropriations.

For the regular beach erosion program, Congress must authorize each feasibility study individually. This is usually done by the Public works Committee of either the House or senate or in some instances by inclusion in a Rivers and Harbors Act. Hearings are held to give local interests an opportunity to make their views public. A general plan is produced after. examining impacts of the project. The project will be recommended for adoption only if it is economically feasible and if the local sponsoring group affirms its willingness to provide its cost share. The Board of Engineers for Rivers and Harbors, the Chief of Engineers, the Governors of affected states, and interested Federal agencies must review the project before congressional authorization. once the project is authorized and funds have been appropriated, the Corps District Engineer performs detailed drawings and specifications on the basis of which contractors make bids. The successful bidder is awarded the contract.

${ }^{1}$ Robert Dolan, U.S. Department of the Interior, National Park Service, Beach Erosion and Beach Nourishment, Dune Stabilization Study, Natural Resource Report No. 4 (Washington: National Park Service, 1972).

${ }^{2}$ U.S. Congress, House, Committee on Public Works, Projects Proposed for omnibus River and Harbor Legislation--1972, Joint Hearings, p. 58 . 
Local interests have some opportunity to make their views known to project planners through hearings and discussions. The local groups have what might be termed bargaining discretion in that they can approve or reject a project by commiting or withholding respectively local requirements. Local funds are limited, and we would expect that local interests would act rationally and seek the best "buys" among their consumption possibilities with their limited resources. They will weigh the benefits and costs of participation with Federal agencies in shoreline protection against the benefits and costs of participation with Federal and nonfederal agencies in the general fields of water, transportation, education and any other area where cost sharing is available. It seems reasonable to hypothesize that the availability of Federal dollars for specific project purposes will affect local decisions on the size, types, and combination or mix of projects that they will be willing to buy.

The corps also exercises discretion in recommending or not recommending a project for authorization. So the outcome of the local-Federal interaction depends upon the bargaining process between the two factions.

It is recognized that many factors other than cost sharing might also affect local willingness to accept Corps projects. The gestation period between the initial request for help and completion of the project is often so long and uncertain that nonfederal interests might feel that they should carry on the project alone. Federal requirements, such as where dredged material should be deposited, may seem prohibitively expensive to local interests even with Federal cost sharing, and consequently they decide to do the job themselves. Finally, the optimal project plan from the national viewpoint might be much larger and more expensive than what the nonfederal interests feel is necessary to meet their particular demands for protection. In effect, each of these factors may result in a higher local cost share, which would probably affect the local demand for corps projects.

It is also acknowledged here that there are many problems outside of cost sharing that hinder the development of an optimal shoreline protection program. The selection of an appropriate discount rate, estimation procedures for future benefits and costs, and institutional complications make determination of optimal shoreline projects difficult. These problems, however, are not examined in this paper. They are assumed to be given in order to isolate for examination here the local incentive effects of cost sharing.

\subsection{Coverage and Structure of the Report}

This study is divided into six chapters. In Chapter 2 the current Federal shoreline protection programs are described. Both the general objectives and the legislation and administrative background of the Federal programs are discussed. The cost-sharing rules incorporated in the beach erosion, hurricane protection, and emergency protection programs are described in detail. Differences and similarities in the rules are emphasized.

A general model of cost sharing for shoreline protection is provided in Chapter 3 . A brief survey of the literature describes what has been done and what is needed in cost-sharing research. The demand by local interests for shoreline protection is derived as a function of the percentage rate of cost sharing to demonstrate analytically cost sharing as a local incentive. Cost-sharing rules are derived that induce local interests to support the nationaliy efficient protection projects with respect to the techniques and the scale of protection.

A description of actual percentage cost shares and of their efficiency impacts is made in Chapter 4. Differences in cost sharing are compared by technique and by program. In chapter 5 existing and alternative cost-sharing rules are evaluated with respect to efficiency, equity, and administrative feasibility.

The report is summarized in Chapter 6. Recommendations are made for policy changes in some existing rules and in some existing institutions that affect cost sharing. Recommendations are also made to retain some of the existing rules and institutions. Finally, suggestions are made for further research. 

The size of the group benefiting from the project is a more nebulous characteristic. If the number of public and private landholders along a section of the beach is small, they can be left to work out a scheme that is beneficial to them. However, if we consider the protected shore to include that area seaward of the mean high water level, regarding it in other words as national property, then the potential benefiting group becomes extremely large, i.e., the entire nation, and it would be impractical to expect them to work out a profitable scheme. On this basis some government involvement might be justified. The answer to what is the relevant benefiting group becomes further complicated if, given that we accept the seaward area as national property, there is still only limited or no public access to the beach.

Finally, the production of public goods often results in effects not considered by the producer or consumer in his private calculation of benefits and costs. These are referred to as spillovers or externalities. An example of an external diseconomy or negative spillover is the starving of a beach area downdrift from an engineering structure that traps sand. The project builder might regard the protective structure as a success within the confines of his part of the beach, but he is ignoring the spillover effects on society in the form of sand depletion on his neighbors' beaches. In effect, the damaged party can neither prevent the builder from entrapping the sand nor make him provide adequate compensation. The rationale for government involvement in this case is to broaden the calculus of benefits and cost to cover all parties so that resources will be allocated most efficiently for the nation.

The second situation which merits government participation on efficiency grounds is declining average costs of production. Economies of scale yield diminishing average costs of production as project output is increased. Private producers, however, may be induced by the profit motive to produce less than the nationally efficient level of output under conditions characterized by economies of scale. For example, in order to reap the full benefits of economies of scale, and in order to maximize net national benefits of shoreline protection, perhaps 5 miles of shoreline would require groin structures, whereas private interests would not find it desirable to develop more than 1 mile, and even then not as an integrated project. Thus to take advantage of economies of scale, government involvement might be necessary. (Note that justification of government involvement here depends on technical conditions of production rather than on any public good characteristics of the output.)

To summarize, we can state that there are probably some public good attributes in shoreline protection and some elements of decreasing cost that would support government involvement.

Government involvement in shoreline protection and in other programs is often claimed to be justified on a less rigorous basis than efficiency, namely that government participation is in the "national interest" or "public interest." The Federal government it is argued has historically helped people protect their lives and property from major disasters. This function would generally be considered in the national interest. 'Iwo of the three legislative programs investigated in this report deal specifically with protection from extreme events such as floods and hurricanes, which may result in disasters of widespread effects. However, it is not the duty of the government to guarantee protection to the public against all possible damaqes from "acts of God" which could have been foreseen and provided for on a probabilistic basis.

The terms "national interest" and "public interest," are often used freely to build support for Federal aid to large projects or to defend Federal aid where no public goods or services are involved. However, the use of these terms does not necessarily preclude the presence of true public goods and services, as illustrated by the following statement by General Koisch:

...the public interest in...private shores is considerable. The management of private lands may affect public beaches, navigation channels, and other facilities. Adverse ecological and environmental problems do not end at private fences, nor do the problems associated with storm flooding and disaster-related emergencies. Private as well as public lands inevitably need to be considered in shoreline and coastal zone planning in order to fully reflect the total public interest. ${ }^{1}$

\footnotetext{
${ }^{1}$ U.S. Congress, House, Committee on Public Works, Projects Proposed for Omnibus River and Harbor Legislation--1972, Joint Hearings, $p . \overline{58}$.
} 
Hence, given these grounds for Federal involvement, and given the additional fact that structural works for shoreline protection are very expensive (see Appendix A), it is only natural that local interests have turned to the Federal government to share with them at least some of the costs for protection.

\subsection{Legislative and Administrative Background of Federal Programs ${ }^{1}$}

Federal involvement in shoreline problems prior to 1930 was restricted mostly to improvements in navigation and protection of Federal property. In 1930 Congress authorized the Chief of Engineers to study the ocean and Great Lakes shorelines with the purpose of devising ways to prevent erosion from waves and currents. Congress further established a seven member Beach Erosion Board which was to make studies of beach erosion problems in cooperation with nonfederal public agencies. ${ }^{2}$ The Beach Erosion Board was given additional powers in 1945 through P.L. 79-166. It was to state in every report its opinion regarding the advisability of adopting projects, the degree of public interest involved in those projects, and the share of project costs the United States should bear.

Specific cost-sharing rules for the corps were outlined by P.L. $79-727$ as amended by subsequent bills. ${ }^{3}$ The Act stated that it

...be the policy of the United States...to assist in the construction

but not the maintenance, of works for the restoration and protection

against erosion, by waves and currents, of the shores of the United

states, its Territories and possessions. ${ }^{4}$

The Federal share of construction cost was not to exceed $50 \%$ of the cost of a project on nonfederal lands except where the project was to protect a publicly owned shore park and conservation area or to provide hurricane protection, in which cases the Federal share could not exceed $70 \%$ of the costs exclusive of land costs. Private shores could be afforded some cost sharing by the corps, the amount to be in proportion to public benefits that would arise from erosion protection. ${ }^{5}$ Cost-sharing rules for hurricane protection were further outlined in the Flood Control Act of 1958.

In 1955 the Corps, in an amendment to the Flood Control Act of 1941, was authorized an emergency fund "...to be expended in flood emergency preparation, in flood fighting and rescue operations, or in the repair or restoration of any flood control work threatened or destroyed by flood...." 6

The Flood Control Act of 1962 amended Public Law 84-99 to provide specific authority for federally authorized hurricane and shore protection works as follows:

That there is hereby authorized an emergency fund expended... in the emergency protection of federally authorized hurricane or shore protection being threatened when in the discretion of the chief of Engineers such protection is warranted to protect against imminent and substantial loss to life and property; in the repair and restoration of any federally authorized hurricane or shore protective structure damaged or destroyed by wind, wave, or water action of other than an ordinary nature when in the discretion of the Chief of Engineers such repair and restoration is warranted for the adequate functioning of the structure for hurricane or shore protection.?

${ }^{1}$ For a collection of the laws relating to shoreline protection, see U.S. Department of the Army, Corps of Engineers, Shore protection Program, pp. 1-1 to 1-10.

${ }^{2}$ River and Harbor Act, P.L. 71-520, 7lst Cong., July 3, 1930, Sec.. 2 .

${ }^{3}$ Amending bills are P.L. 84-826, P.L. 87-874, P.L. 89-298, and P.L. 91-611.

${ }^{4}$ River and Harbor Act, P.L. 79-727, 79th Cong., August 13, 1946, Sec. 1.

${ }^{5}$ Ibid.

${ }^{6}$ Amendment in Flood Control Act of 1971, P.L. 84-99, 84th Cong., 1st. Sess., June $2 \overline{8,1955 .}$

Flood Control Act, P.L. 87-874, 87th Cong., October 28, 1962, Sec. 206. 
The emergency works discussed in the above authority are exclusively for those projects specifically authorized by Congress or authorized by the Chief of Engineers under a special continuing authority. The corps does not have any authority for the emergency protection of nonfederal works being threatened nor the repair or restoration of such works damaged by a storm. However, this does not preclude the Corps from furnishing emergency flood fighting assistance during a storm. This paper treats emergency work provided under P.L. 84-99, as amended, but not under the Disaster Relief Act of 1970 .

In 1963 the Beach Erosion Board was replaced by the Coastal Engineering Research Center (CERC), which retained most of the functions of the Board. ${ }^{2}$ CERC conducts research on shore processes, storm frequencies, storm-tide elevations, and other topics of use to the District Corps offices that design shoreline projects.

Numerous House and Senate bills to amend the cost-sharing responsibility of the Federal government, usually to increase the Federal share, have come before the congress in recent years, ${ }^{3}$ indicating the continuous legislative concern about cost sharing for shoreline protection. The implications of these alternative cost-sharing rules will be evaluated along with existing rules in chapters 4 and 5.

General policy documents as well as legislation dealing directly with shoreline protection have had some impact on the planning of shoreline protection projects. The "Green Book," "Budget Circular A-47," and "Senate Document 97" are three such documents, although none has statutory standing. ${ }^{4}$

The Green Book, authorized for publication by the Inter-Agency Committee on Water Resources, was published with the hope that interested parties in the water field would consider its proposals. It was not issued as an official procedural guide as were Budget Circular A-47 and Senate Document 97.

The Green Book established certain evaluation practices for water-resource development in general. It definer the efficient scale of development as that level at which net benefits are a maximum (where marginal benefits equal marginal costs), and it specified that the cheapest (most efficient) technique(s) of providing a project purpose should be adopted. ${ }^{5}$ However, no relationship between these efficiency conditions and cost sharing was described in the Green Book.

Budget Circular A-47 was a directive prepared by the Bureau of the Budget (now the office of Management and Budget) to inform all water-resource agencies of the standards and procedures used by the Executive office of the President in reviewing reports and budget estimates of proposed water-resource developments. It was an official procedural guide designed to encourage the agencies to adopt a more uniform planning policy than that which had been followed in the past.

The circular emphasized that project plans must show which parts of project costs are to be borne by the various participating parties and that the Federal construction agency mist indicate legislative or other authority for proposing that certain costs are nonreimbursable. ${ }^{6}$

'Disaster Relief Act, P.L. 91-606, 9lst Cong., December 31, 1970 .

${ }^{2}$ River and Harbor Act, P.L. 88-172, 88th Cong., November 7, 1963.

${ }^{3}$ For a detailed discussion of two shoreline bills, see the following Hearings for 1972 and 1970: U.S., Congress, Senate, Committee on Public Works, Omnibus Water Resources Authorizations, Hearings, before the Subcommittee on Flood Control--Rivers and Harbors, Senate, for S-3603, 92nd Cong., 2nd Sess., 1972, pp. 595-664; and for s-3774, 91st Cong., 2nd Sess., 1970, pp. 649-677.

${ }^{4}$ In the order listed above, the documents are: U.S., Subcommittee on Evaluation Standards, Proposed Practices for Economic Analysis of River Basin Projects, Report to the Inter-Agency Committee on Water Resources (Washington, D. C. rev. ed., 1958); U.S. Bureau of the Budget, "Circular on water Resources Projects," Budget Circular No. A-47 (Washington, D. C., 1952); and U.S. Congress, Senate, Policies, Standards, and Procedures in the Formulation, Evaluation, and Review of Plans for Use and Development of Water and Related Land Resources, prepared under the direction of the President's Water Resources Council, Senate Document 97, 87th Cong. 2nd sess., 1962.

${ }^{5}$ U.S., Subcommittee on Evaluation Standards, Green Book, p. 1114.

${ }^{6}$ U.S. Bureau of the Budget, Budget Circular A-47, pp. 12-13. 
The Department heads of the Army, the Interior, Agriculture, and Health, Education, and Welfare prepared Senate Document 97, which superseded the documents described above. It was aproved by both the President and by the Bureau of the Budget, and it became the "guide book" to which water-resource agencies turned for criteria to be used in planning and reviewing water-resource projects. Planning multiple-purpose projects was encouraged, and the developing agencies were to consider all viewpoints -- national, regional, state, and local.

The objectives and promises of senate Document 97 were stated as follows:

...to establish Executive policies, standards and procedures for uniform application in the formulation, evaluation, and review of comprehensive river basin plans and individual project plans for use and development of water and related land resources. Problems of cost allocation and of reimbursement or cost sharing between the federal government and nonfederal government bodies will be covered subsequently. 1

The promised examination of cost allocation and cost sharing was never completed. Even so, since the Document included the basic conditions of (l) planning for the scale at which marginal benefits equal marginal costs and (2) picking the least-cost technique(s) for accomplishing a given purpose, ${ }^{2}$ it is relevant for our purposes.

The Water Resources Council's Proposed Principles and Standards for Planning Water and Related Land Resources ${ }^{3}$ has also affected the development of water projects. This report was approved by President Nixon in a letter to the Chairman of the Water Resources Council on August 3, 1973.4 The Corps and other agencies will focus their planning in the direction recommended by the document. Specifically, the Principles and standards, as amended, call for planning water projects to maximize net benefits from two objectives -- national economic development and environmental quality. Each of these objectives is made up of many components or project purposes for which benefits are to be measured and to which costs are to be allocated. Yet, except for the recommended local cost share of $50 \%$ for the water quality component of the environmental quality objective, there is no new policy position on cost sharing. The Principles and Standards treat cost sharing in the following manner:

Current reimbursement and cost-sharing policies will be reviewed in their entirety at an early date in light of experience gained from actual application of the new principles and standards. At that time the basis for reimbursement and cost sharing now required, the need for adjustment of these policies, the need for new reimbursement and cost-sharing policies for other objectives and their components or entirely new approaches and appropriate repayment arrangements and interest rates for repayment will be extensively reviewed. Until this comprehensive review is completed, all current reimbursement and cost-sharing policies are considered to be in full force and effect. 5

Thus the Principles and Standards, like Senate Document 97, fails to review cost sharing for water resource development.

President Nixon, in his approval letter to the Chairman of the Water Resources council, recognized the need for prompt action on cost sharing.

${ }^{1}$ U.S. Congress, Senate Document 97, Sec. 1 .

${ }^{2}$ Ibid., V(C) (2).

${ }^{3}$ U.S., Water Resources Council, "Proposed Principles and Standards for Planning Water and Related Land Resources," pp. 24144 - 24194.

${ }^{4}$ Richard Nixon, President of the U.S., Letter to Honorable Rogers C. B. Morton, Chairman, Water Resources Council, 2120 L Street, N.W., Washington, D.C. 20037.

${ }^{5}$ U.S. Water Resources Council "Proposed Principles and Standards for Planning Water and Related Land Resources," p. 24183. 
I understand that analysis of ways to assume more equitable cost sharing by the beneficiaries of water resources projects is underway. I ask that you complete this work promptly so that draft legislation can be transmitted to Congress in time for enactment this year. ${ }^{1}$

The most current review of cost sharing has been provided in the final report of the National Water Commission. ${ }^{2}$ It describes and appraises current cost-sharing rules for many water programs. The conclusions in part are as follows:

...appropriate cost-sharing policies should provide incentives

for the selection of efficient projects that will lead to progress

toward water resources policies that are in harmony with other national programs and policies.... Cost-sharing policies should be equitable, with project beneficiaries bearing proportionate shares of project costs. ${ }^{3}$

The National Water Commission Report gives specific recommendations for cost sharing policies that will lead to the achievement of the goals specified above. The key recommendation is that "...the identifiable beneficiaries of project services should bear appropriate shares of development and operating costs through systems of pricing or user charges..." 4

The following section describes in detail the present cost-sharing rules for shoreline protection, their differences, and problems that arise from these differences.

\subsection{Present Federal-Local Cost-Sharing Rules}

In this section we review the three Corps programs that provide shoreline protection. Each program has its own authorizing legislation and internally produced Corps Engineering Manuals or Engineering Regulations that dictate how costs will be shared and under what conditions local groups are eligible for Federal cost sharing under that program. The programs are differentiated here by the type of shoreline protection they provide; i.e., hurricane protection versus emergency protection versus normal beach erosion protection. Each of the programs is discussed, and differences within and among the three programs are emphasized.

\subsubsection{Hurricane, Tidal, and Great Lakes Flood Protection}

The purpose of the Federal hurricane flood protection program is to protect those areas bordering oceans, estuaries, and the Great Lakes from inundation caused by hurricanes (and other high winds) or by exceptionally high tides. In the course of providing hurricane protection, normal beach erosion will ordinarily be prevented, too. But it is important to recognize that this program is intended primarily for protection against exceptionally high tides, and that areas not encountering these severe flooding processes would not be eligible, theoretically, for protection under this program.

The current Corps policy for hurricane protection cost sharing is detailed in an Engineering Regulation, ${ }^{5}$ but the precedents for these rules lie in the cost-sharing formulas adopted in the Flood Control Act of 1958 for specific shoreline projects. It should be noted that there is no connection between cost sharing and the degree of public (albeit nonfederal) ownership and use. Cost sharing is relatively fixed for projects authorized and funded under the hurricane protection program. Council.

${ }^{1}$ Richard Nixon, President of the U.S., Letter to Chairman of the Water Resources

${ }^{2}$ National water Commission, Water Policies for the Future: Final Report to the President and to the Congress of the United States (Washington: U.S. Government Printing office, 1973), pp. 485-499.

${ }^{3}$ Ibid. , p. 496 .

${ }^{4}$ Ibid., p. 497 .

${ }^{5}$ U.S. Department of the Army, Corps of Engineers, Federal Participation in Coastal Protection Projects, ER-1165-2-19, August 20, 1969, pp. $1-7$.

${ }^{6}$ Flood Control Act, P.L. 85-500, 85th Cong., July 3, 1958, Sec. 203. 
Table 2.1 displays the maximum Federal cost shares under the three Corps programs for nonfederal shore areas. ' For hurricane protection, the Federal share ranges up to $70 \%$ for the costs of construction; lands, easements, and rights-of-way; and for relocation and alteration of utilities. Thus the local share for these first costs is at least $30 \%$

operation and maintenance (O\& M) cost, necessary for ensuring continued operation of the project through its planned life span, is generally a nonfederal responsibility. When performance of $O \& M$ by the Federal government is assumed to be in the public interest, nonfederal interests may be required to make a cash contribution in the amount of the estimated present value of $O \& M$, capitalized at the current Federal discount rate. ${ }^{2}$ A Federal tax or subsidy could result for local participants if the Federal rate were different from the market rate. The amount of the tax or subsidy respectively would be the difference in the capitalized value of $O \& M$ with the market rate of interest and with a lower or higher Federal rate.

Pre-authorization surveys in the project area and aids to navigation required by the project are financed totally at Federal expense.

\subsubsection{Emergency Flood and Coastal Storm Protection}

The purposes of this program are to prepare for flood and coastal storm emergencies, provide flood fighting and rescue work, and to repair and restore flood control works and Federally-authorized and constructed shore protection structures. ${ }^{3}$ ("Federally constructed" means only that the corps lets bids for the repair of the project by private enterprise.)

Assistance by the corps is intended to supplement state and local resources. Thus the authorizing legislation (P.L. 84-99 and P.L. 87-874) does not provide explicit cost-sharing rules for the corps. The policy adopted by the Chief of Engineers for local cooperation is based on local requirements specified in the $1936 \mathrm{Flood}$ Control Act and set forth in a Corps Engineering Regulation. ${ }^{4}$

Table 2.1 displays the maximum Federal cost shares for emergency protection. The maximum federal share for construction costs, pre-authorization surveys, and aids to. navigation is $100 \%$. Local interests are required to bear the costs of lands, easements, and rights-of-way; $O \& M$; and relocation and alteration of utilities. In specific cases, the Chief of Engineers can eliminate any of these local cooperation requirements upon adequate justification. ${ }^{2}$ However, except for $O \& M$ costs, local interests have already provided these requirements for the original project.

Much of the Corps work under the emergency protection program is flood fighting, including advanced flood fighting in the form of strengthening project features where preservation of a Federally constructed project is threatened. Shoreline protection performed under this program is usually in the form of repairs to Federally constructed structures following damaging storms, and shoreline protection per se is only a small proportion of the Corps' total activities under the emergency protection program.

Although this report treats emergency protection under P.L. $84-99$ only, it should be pointed out that the Corps does have the authority under the Disaster Relief Act of 1970 to provide beach restoration even where there has been no Federally authorized project. However, this authority can be exercised only when the President has declared the event a major disaster. The same cost sharing described above applies.

${ }^{1}$ The Federal government bears the full costs of protection of Federal lands.

${ }^{2}$ U.S. Department of the Army, Corps of Engineers, Federal Participation in Coastal Protection Projects, p. 4 .

${ }^{3}$ U.S. Department of the Army, Corps of Engineers, Emergency Employment of Army and Other Resources, ER 500-1-1, January 4, 1972, p. 1-1, Sec. 11-10.

${ }^{4}$ Ibid. , p. 5-4, Sec. 53-20.

${ }^{5}$ Ibid. 


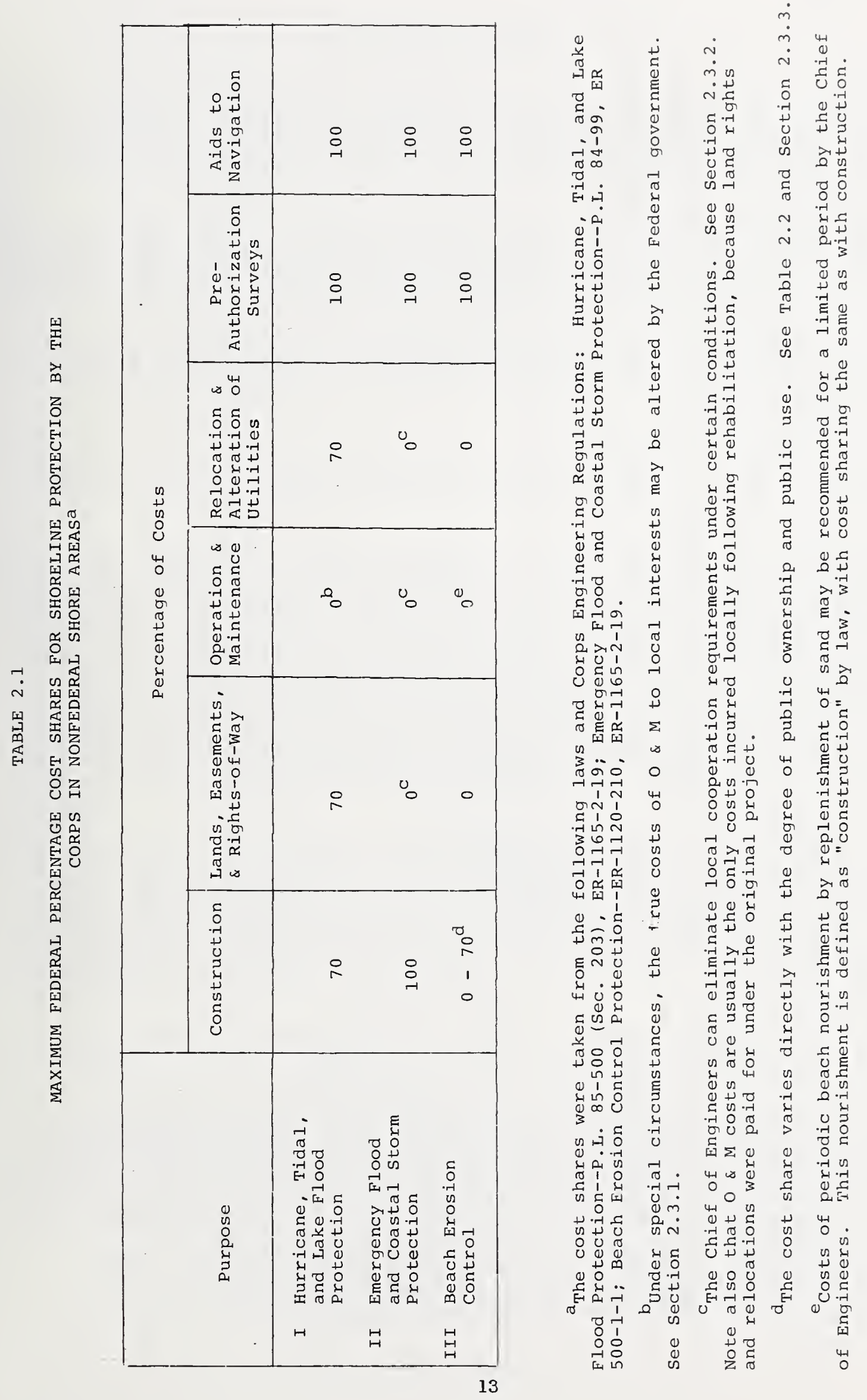




\subsubsection{Beach Erosion Control}

The beach erosion control program is for the purpose of preventing erosion damages resulting from wave and current action against shores and beaches. Structural measures for such projects are designed to protect a specific area against normal erosion processes rather than the severe storm that is likely to occur only once in 100 or in 200 years. The latter, more expensive type of protection is provided in the hurricane program described in Section 2.3.1.

Cost sharing of construction costs under the beach erosion control program differs significantly from hurricane protection in that the degree of Federal cost sharing for beach erosion control is a direct function of public ownership and use of the protected shoreline. Thus, the percentages as well as the absolute values of project construction costs borne by Federal and nonfederal interests will vary from project to project.

Table 2.1 shows that the maximum Federal share of construction costs varies from $0.0 \%$ to $70 \%$ for the beach erosion control programs. The costs of lands, easements, and rights-of-way; $O \& M$; and relocation and alteration of utilities are borne by local interests. Pre-authorization surveys and aids to navigation are provided at Federal expense.

A more complete description of cost sharing for the beach erosion control program is given in Table 2.2.1 The table illustrates the maximum Federal shares to be paid under five categories of ownership of shore frontage with varying degrees of public benefits or use.

For category I, Federally owned land, all costs are borne by the Federal government. Category II comprises property which (1) is publicly owned; (2) includes a zone landward from the mean low water line that excludes building for habitation (thereby preventing development that would be vulnerable to storm and water damages); (3) includes a beach for recreational use; (4) provides for the preservation, conservation, and development of the environment (i.e., to maintain game preserves and natural conditions in some areas while providing facilities for intense recreational use in others); (5) includes natural protective features such as dunes to act as a buffer zone between upland development and the active shore zone; and (6) provides the public with full park facilities commensuratewith intended park use. Note that the second requirement of a zone excluding building amounts to a land management alternative to engineering techniques for controlling shoreline damages; note also that the $70 \%$ share provides a local incentive for adoption of management techniques and natural protective forces as opposed to residential or commerical development and engineering protective structures.

Lands, easements, and rights-of-way costs plus O \& M costs must be borne by local interests, although the costs of pre-authorization surveys are still borne by the Federal faction. One cost can be shared by the Federal government, however, and that is the cost of periodic beach nourishment. ${ }^{2}$ If beach nourishment is considered as a method of shoreline protection, the chief of Engineers may recommend a time (usually 10 years) during which Federal aid may be given. On the other hand, when maintenance is the primary purpose of periodic beach nourishment, i.e., if used in conjunction with structural measures that confine the restored beach, Federal cost sharing cannot be granted.

Category III shoreline is publicly owned, but does not meet the special park or conservation requirements of category II shoreline. Only a $50 \%$ Federal cost share is available for construction.

Categories IV and V cover privately owned property. Here the applicable principle relating to cost sharing is that the greater the extent of public benefits present, the larger the Federal cost share for which private property will be eligible. Public benefits include public recreational use and prevention of damage to public facilities such as boardwalks, buildings, highways, and parks. The Federal cost share (percentage) for Category IV properties -- privately owned properties which provide measurable public benefits -- is computed by multiplying 50\% times the ratio of public benefits to total

${ }^{1}$ U.S. Department of the Army, Corps of Engineers, Federal Aid Toward Shore Restoration and Protection, ER 1120-2-110, March 1, 1965, pp. 1-9.

${ }^{2}$ Periodic beach nourishment, as an engineering technique, is discussed in Appendix A. 


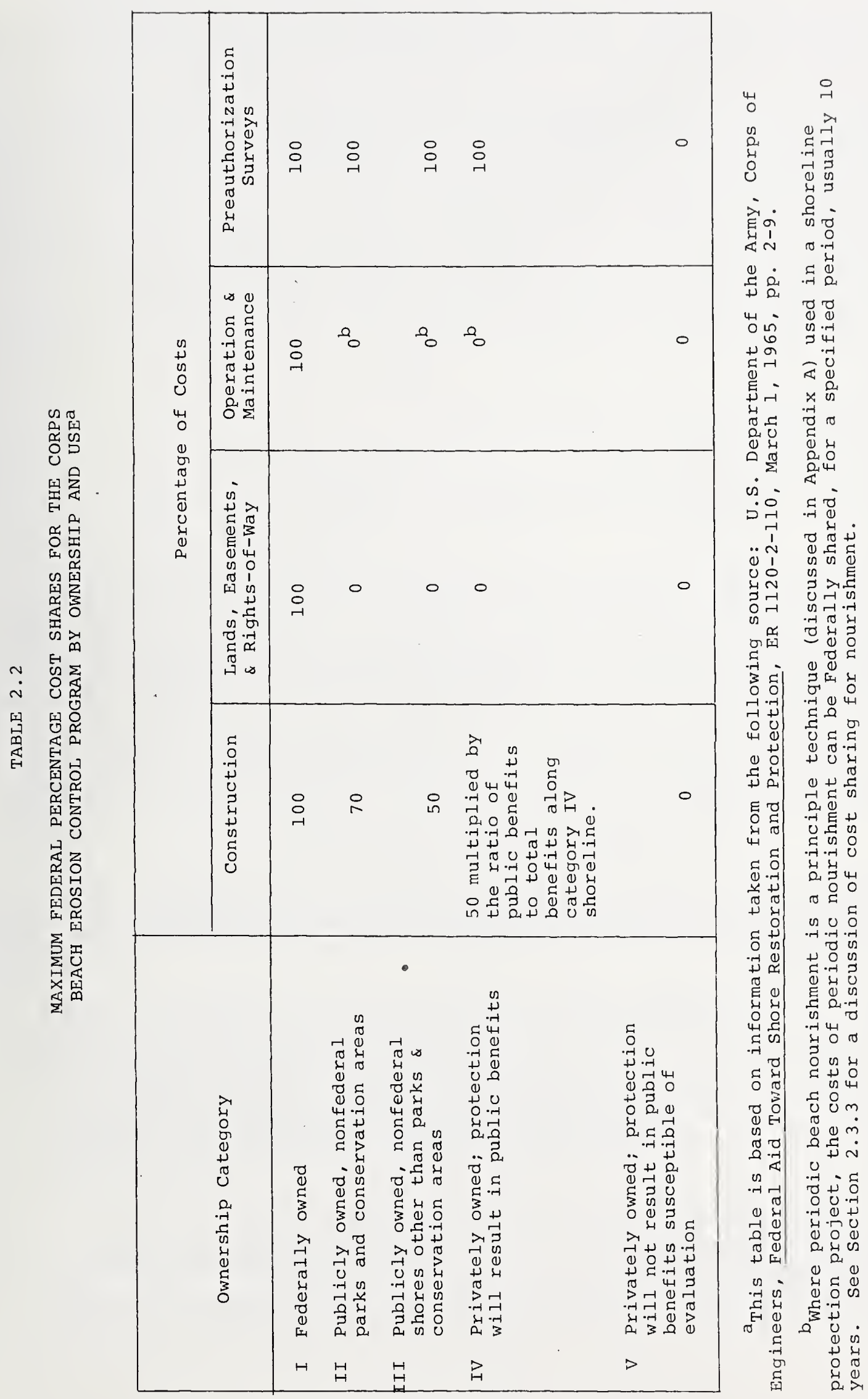


benefits, i.e., the percentage Federal share $=50 \% \times$ public benefits/total benefits. The absolute Federal cost share would be obtained by multiplying the percentage Federal share times construction costs. ${ }^{1}$ Where public benefits accrue mostly in the form of recreational use, then the Federal share varies directly with the degree of public use.

If the property is privately owned and protection does not result in measurable public benefits (Category $V$ ), then the project is not eligible for Federal assistance under the beach erosion control program. Federal cost sharing at the 50\% rate is available for both Category IV and Category V property, however, when the overall project provides only minor or incidental benefits to private interests and the cost of providing these private benefits by the project is equal to or less than the costs of providing only public benefits with the project.

To compute the absolute dollar cost shares for any given category of shoreline, one need simply multiply the percentage shares times the costs of construction. However, where a project encompasses several or all of the described categories of beaches, the formula ${ }^{2}$ used is as follows:

The percentage Federal share of total construction cost $=$

$\left\{\left[\begin{array}{l}\text { Category I Frontage } \\ \text { Total Frontage }\end{array}\right]+\left[\begin{array}{lll}\frac{\text { Category II Frontage }}{\text { Total Frontage }} & \times & 0 . \overline{7}\end{array}\right]\right.$
$+\left[\frac{\left(\frac{\text { Category III Frontage }}{\text { Total Frontage }}\right)+\left(\frac{\text { Category IV Frontage }}{\text { Total Frontage }}\right.}{}\right.$
$\left.\left.\left.\times \quad \frac{\text { Public Benefits Along Category IV Frontage }}{\text { Total Benefits Along Category IV Frontage }}\right]\right] \times 0.5\right\} \times 100$.

If the cost of construction per unit of benefited frontage is not relatively uniform, the project must be divided into compartments that meet this condition. The above formula can then be applied to total construction costs with each compartment.

Some projects satisfy beach erosion control as well as hurricane protection. For these multiple-purpose projects, total costs are allocated among the various purposes so that cost shares can be determined by purpose according to the prescribed rules for that purpose. Cost allocation in multiple-purpose projects is recognized as influential in affecting cost shares and the choice of scale and techniques. For example, local interests will be biased by cost-sharing rules to want as much as possible of the total costs of a joint beach erosion-hurricane project allocated to hurricane protection because their share will be minimized with that allocation. For a more complete discussion of cost allocation and how it relates to cost sharing, see Marshall and Broussalian. ${ }^{3}$

\subsubsection{Comparison of Cost-Sharing Rules}

Differences or inconsistencies among cost-sharing rules can be expected to influence local choices of shoreline protection programs. In this section, therefore, we summarize the differences among the rules described in earlier sections. Full analysis and evaluation of the efficiency and equity effects of these differences will be attempted in Chapters 4 and 5 .

One major difference among the three programs relates to the criteria of eligibility. While all projects must demonstrate positive net benefits to be eligible for Federal assistance, a major difference exists between the beach erosion control program and the other two. Applicants for aid under the beach erosion control program must demonstrate public ownership or public use to be eligible for assistance, whereas neither is required under the hurricane or emergency protection programs. Hence, projects providing the same general service, shoreline protection, and possibly using the same technique, e.g., an engineering structure, can have different eligibility requirements for Federal participation.

${ }^{1}$ When privately owned shores are under public control, as through a long-term lease, they may be treated as Category III land for cost-sharing purposes.

${ }^{2}$ U.S. Department of the Army, Corps of Engineers, Federal Aid Toward Shore Restoration and Protection, p. 5.

${ }^{3}$ Marshall and Broussalian, "Federal Cost Sharing Policies for. Water Resources," pp. $28-34$. 
A second major difference among the three programs is the percentage cost shares borne by the Federal government. For construction the Federal share ranges from lo0\% under the emergency protection program down to 0.0 \% for some privately owned land under the beach erosion control program. Federal cost shares also differ for other types of costs. For example, lands, easements, and rights-of-way expenses are borne totally by local interests in the emergency and beach erosion control programs, but the Federal share is as high as $70 \%$ for the hurricane protection program. Operation and maintenance can be shared under both the hurricane protection program and the emergency program under special circumstances, but not for the beach erosion program except under the guise of periodic beach nourishment. And relocation and alteration of utilities is shared at $70 \%$ for the hurricane protection program, but at $0.0 \%$ for the other programs. Within the beach erosion control program itself there are differences in cost sharing, depending on the degree of public ownership and use, as discussed earlier. Tables 2.1 and 2.2 show that the three shoreline protection programs vary considerably in terms of cost sharing.

A third difference, which exists between emergency protection and the other two programs, should also be noted. The nature of emergency protection is restoration and repair of existing Federally authorized shoreline protective structures, whereas the other programs are for new projects.

Because emergency protection is thought to be needed quickly to protect property and lives, we might expect the Federal share to be higher than for the other programs. It is less obvious, however, why beach erosion control and hurricane protection, two purposes that are quite similar in nature, should have different eligibility requirements for Federal aid and different rules for Federal cost sharing. Hurricane protection projects appear to differ from beach erosion control projects only in that they provide bigger and stronger forms of protection. Thus, there is no apparent reason for different cost-sharing rules.

There have been some steps towards making the percentage cost shares equal for the two purposes. Senator Javits introduced a Bill, $\mathrm{S} .3774$, in the 2 nd session of the 9 lst Congress that would allow the Chief of Engineers in the Corps to provide a Federal cost share up to $70 \%$ of construction costs if hurricane protection is included as a part of a multiple-purpose project. This would, in effect, raise the maximum Federal share from around 50\% to $70 \%$ for that part of the project which is supposed to be for beach erosion control. Senator Javits described the need for the bill as follows :

The federal financial participation in beach erosion and hurricane protection projects have been limited by needlessly complex and, in my judgment, unbalanced cost-sharing formulas. These formulas must be adjusted, especially with regard to hurricane protection projects, if we are to preserve our shores and avoid the catastrophe that violent storms often cause. ${ }^{1}$

Section 208 of the 1970 Rivers and Harbors Act (P.L. 91-611) authorized 70\% costsharing for projects including hurricane protection as a purpose to be used at the discretion of the Secretary of the Army acting through the Chief of Engineers. The impact of this section on Corps policy is summarized by the following statement of General Koisch:

...this authority has not been used. We see it as a means for discretionary correction of cost-sharing inequities that may exist in some of these joint projects.

We have not yet come up with criteria to define its applicability. We will, of course, examine all joint hurricane and beach erosion projects with section 208 in mind. But for the time being, at least, we feel that the burden of demonstration lies on those seeking change in the cost sharing. ${ }^{2}$

${ }^{1}$ U.S. Congress, Senate, Introduction of a Bill to Award Cost Sharing for Hurricane Protection Projects, Congressional Record, 9lst Cong., 2nd Sess., April 30, 1970, p. S. 6308 .

${ }^{2}$ U.S. Congress, House, Committee on Public Works, Projects Proposed for Omnibus River and Harbor Legislation--1972, Joint Hearings, p. $\overline{81}$. 
The current procedure for sharing costs of joint beach erosion and hurricane protection projects, as outlined in Corps Engineering Regulation 1165-2-19, is to first allocate total project costs between the two purposes and then to assign the appropriate cost-sharing rules. The controversy has centered upon whether or not that part of total project cost allocated to beach erosion should be Federally shared at $70 \%$ rather than at the existing maximum for privately owned beaches of 50 . By the same token, efficiency and equity arguments might be addressed to support a contrary position, namely a reduction of the $70 \%$ share paid for hurricane protection to a uniform share of $50 \%$ for both single and multiple-purpose projects.

One similarity among the three programs appears especially significant. Cost sharing does not vary by engineering techniques within any given program; that is, the percentage share that local groups must pay will be the same whatever technique of protection might be used. Thus, on cost-sharing grounds, there is no incentive to pick one engineering technique in preference to another. The same is not true as between engineering techniques and management techniques for which the Corps does not have full authority. Appendix A describes the full range of engineering and management techniques that are available for determining the optimal shoreline protection program. 


\section{THEORETICAL CONSIDERATIONS}

This chapter develops a model which illustrates how cost sharing affects local decision-making in planning shoreline protection projects.

First, a brief survey of selected literature on cost sharing is presented for shoreline protection and for water resources development in general. Reference is also made to some general works on grants-in-aid, a form of cost sharing. The purpose of the literature survey is to provide a sketch of thinking about cost sharing. The interested reader may pursue the subject on his own by consulting the references cited in the footnotes.

Second, the demand for shoreline protection by local interests is derived to demonstrate the impact on local willingness to buy shoreline protection as a function of cost-sharing percentages. The third section derives a system of cost sharing that encourages local interests to select nationally efficient or optimal projects.

\subsection{Selective Survey of the Literature ${ }^{1}$}

Much of the literature on cost sharing in water resources development focuses on political and administrative problems rather than economic problems. Inefficiencies and inequities are often cited as primary problems, but they are seldom discussed analytically. The writings to be considered here are selected on the basis of their analytical contribution to cost sharing; i.e., in so far as economic theory has been applied to cost sharing problems. The paucity of such writings, particularly on the issue of shoreline protection, is one of the reasons why this study was undertaken.

Davis and Hanke have provided some economic analysis of the hurricane protection and beach erosion programs in their report entitled Pricing and Efficiency in Water Resource Management. ${ }^{2}$ They identify a "two-pronged government subsidy" in the form of disaster relief made available through the Disaster Act and in the form of the $70 \%$ Federal cost share for hurricane protection. ${ }^{3}$ Davis and Hanke criticize the dual shoreline subsidy because it fails to discourage people from moving into disaster-prone areas. They recommend insurance as one solution. By charging individuals a beneficiary charge, i.e., an insurance premium, protection would be provided in the event of a disaster and, what they consider more important, unwise development in the flood-prone area would be discouraged. ${ }^{4}$

Loughlin has recommended a cost-sharing policy for structural flood protection that is related to the flood insurance program. ${ }^{5}$ To ensure efficiency and equity, he recommends that local beneficiaries of a flood protection project share project costs in the same proportion that local benefits (i.e., local reductions in flood insurance premiums and noninsurable damages) bear to total benefits from the project. ${ }^{6}$

${ }^{1}$ For a more comprehensive survey of the literature on cost sharing, see Harold E. Marshall, "The Relationships Between Local Cost-Sharing and Efficient Water-Resource Development (unpublished Ph.D. dissertation, The George Washington University, 1969), pp. 56-89.

${ }^{2}$ Robert K. Davis and Steve H. Hanke, Pricing and Efficiency in Water Resource Management, Reproduced by National Technical Information Service, No. PB-209-083 (Springfield, Va.: NTIS, 1971), pp. 151-160.

${ }^{3}$ Ibid. , p. 153-154.

${ }^{4}$ Ibid. , p. 154 .

${ }^{5} \mathrm{James} C$. Loughlin, "A Flood Insurance Model for Sharing the Costs of Flood Protection," Water Resources Research, VII, No. 2 (April, 1971), pp. 236-244.

${ }^{6}$ Ibid. , p. 239. 
Loughlin has also examined cost sharing in water resources apart from insurance. He emphasizes that differences in cost-sharing policies within an agency and among agencies lead to social ineffiencies and inequities. ' Loughlin recommends a uniform approach to the sharing of costs for flood protection to effect greater efficiency and equity. ${ }^{2}$

Marshall has derived the necessary conditions in cost sharing ${ }^{3}$ for encouraging local interests to select the least-cost combination of techniques and the nationally efficient project scale for providing any given water resource project. The condition for encouraging the selection of the least-cost combination of techniques is that local interests be charged the same percentage cost share for each technique available to them. The necessary condition (called the Association Rule) for encouraging local support of the nationally efficient scale is related to the benefit theory of taxation and requires that local interests be charged according to the benefits that they receive. ${ }^{4}$ Marshall shows that current cost sharing rules for many of the water programs do not meet these conditions. ${ }^{5}$

Marshall and Broussalian have analyzed cost sharing in water resources for satisfying not only the single traditional objective of national economic development, but also for satisfying multiobjectives that include environmental quality and regional development. ${ }^{6}$ They have also examined alternative cost-sharing rules for their equity, or fairness, implications. 7

The Marshall and Broussalian report, prepared at the National Bureau of Standards, was used by the National Water Commission in preparation of its final report as a background for Chapter 15 on "Paying the Costs of Water Development Projects." (See Section 2.2 for a brief discussion of the National Water Commission Report.)

Rafuse and Sherman have examined cost sharing specifically for flood control projects. They maintain that the net benefits from a flood control project are not additive among benefiting districts, and therefore that cost sharing formulas should not be based on an addition of these benefits. " They introduce the "net fiscal benefits criterion" as an alternative method for determining what local interests should be willing to pay. It requires simply that local interests be required to pay a share of the project cost that is equal to the net fiscal benefits (e.g., increased tax revenues minus increased local government expenses) that they expect to realize from the project. ${ }^{9}$ Rafuse and Sherman recognize that their criterion will not necessarily achieve efficient project decisions, but they emphasize that it has merit in achieving equity among cost-sharing participants. ${ }^{10}$

${ }^{1}$ James C. Loughlin, "Cost-Sharing for Federal water Resource Programs with Emphasis on Flood Protection," Water Resources Research, VI, No. 2 (April, 1970), p. 377.

Ibid.

${ }^{3}$ The necessary conditions will be discussed in section 3.3 .

${ }^{4}$ Harold E. Marshall, "Economic Efficiency Implications of Federal-Local Cost Sharing in Water Resource Development," Water Resources Research, VI, No. 3 (June, 1970), pp. 673-682.

${ }^{5}$ Ibid. , pp. 677-680.

${ }^{6}$ Harold E. Marshall and Vartkes L. Broussalian, Federal Cost-Sharing Policies for Water Resources, pp. 182-201.

${ }^{7}$ Ibid., pp. 201-214.

${ }^{8}$ Robert W. Rafuse, Jr., and Michael D. Sherman, The Implications of the Net Fiscal Benefits Criterion for Cost Sharing in Flood Control Projects, Mathematica Report to the Corps of Engineers, IWR Report 71-12 (Washington, D. C.: Institute for Water Resources, 1971), p. 49.

$$
\begin{aligned}
& { }_{10}^{9} \text { Ibid., p. } 51 . \\
& \text { Ibid., p. ii. }
\end{aligned}
$$


Earlier writings than those discussed above dealt with cost sharing in water projects in a somewhat less technical fashion. Regan was an early advocate of sharing costs in proportion to benefits. He recognized that local interests would have different viewpoints from those of society, and that these differences, if not compensated for by cost sharing, might encourage local support of projects that were not socially optimal. 1

Renshaw recognized the economic efficiency effects of having different cost-sharing rules for alternative techniques of providing a given project purpose. He pointed out that, for flood protection, local interests would pick that alternative with the highest ratio of Federal to local costs, other things equal, even though that selected alternative might not be the cheapest for society. ${ }^{2}$

Other areas of research involving cost-sharing programs are in agriculture and in grants-in-aid. Hurlburt has derived optimal leasing (cost-sharing conditions) for inducing landlords and tenants to operate a rental farm in such a way that profits are maximized. ${ }^{3}$ Adams and Rask have developed the "ideal" lease or cost-sharing arrangements for tenant farmers in less developed countries. ${ }^{4}$ Writings by McGuire and Garn ${ }^{5}$ and by Break $^{6}$ deal with efficiency in resource allocation through general grant-in-aid (costsharing) programs.

This selective survey of the literature has focused on local incentive effects of cost sharing and its impacts on efficiency and equity. The remainder of the chapter analyzes in detail how cost sharing rules affect local demand for project output, the choice of techniques for building a given project, and the size of the project to be built.

\subsection{Derivation of Local Demand for a Project}

The demand by local interests for shoreline protection must be presumed to depend on the price that they must pay for that protection, and the value they place in this protection, other things being equal. ${ }^{7}$

Assume that the local group's benefit or welfare function can be expressed as

$$
B_{L}=B_{L}(Q, M) \text {, }
$$

where $\mathrm{B}_{\mathrm{L}}=$ benefits accruing to the local group

$Q=$ unit measure (i.e., quantity) of shoreline protection, and

$\mathrm{M}=$ all other goods and services available to the local group, measured in dollars.

${ }^{1}$ Mark Regan, "Sharing Financial Responsibility of River Basin Development," Economics and Public Policy in Water Resources Development, ed. by Stephen C. Smith and Emery N. Castle (Ames, Iowa: Iowa State University Press, 1961), p. 215.

${ }^{2}$ Edward F. Renshaw, Toward Responsible Government: An Economic Appraisal of Federal Investment in water Resource Programs (Chicago: Idyia Press, 1957), p. 50.

${ }^{3}$ Virgil L. Hurlburt, "Farm Rental Practices and Problems in the Midwest," Research Bulletin No. 416 (Ames, Iowa: Iowa State College Agricultural Experiment Station, 1954), p. 85 .

${ }^{4}$ Dale W. Adams and Norman Rask, "Economics of Cost-Share Leases in Less-Developed Countries," American Journal of Agricultural Economics, L, No. 4 (1968), p. 935.

${ }^{5}$ Martin C. McGuire and Harvey A. Garn, "Problems in the Cooperative Allocation of Public Expenditures," Quarterly Journal of Economics, LXXXIII, No. 1 (1969), pp. 31-39.

${ }^{6}$ George F. Break, Intergovernmental Fiscal Relations in the United States (Washington, D. C.: The Brookings Institution, 1967).

${ }^{7}$ This analysis is based on a similar derivation described in Harold E. Marshall, "The Relationships Between Local Cost-Sharing and Efficient Water-Resource Development," pp. 25-28. 
The local group is constrained in its purchase of $M$ and $Q$ by the amount of wealth available to it, i.e., its budget. Therefore the local group will maximize its welfare (other things being equal) subject to the budget constraint which satisfies the relationship

$$
\begin{aligned}
\mathrm{L} & =\mathrm{M}+\mathrm{C} \cdot \mathrm{P} \cdot \mathrm{Q} \\
\text { where } \mathrm{L} & =\text { local budget }, \\
\mathrm{C} & =\text { percentage local cost share, } \\
\mathrm{P} & =\text { national price per unit of } \mathrm{Q}, \\
\mathrm{C} \cdot \mathrm{P} & =\text { local price per unit of } \mathrm{Q}, \text { and } \\
\mathrm{C} \cdot \mathrm{Q} & =\text { absolute local costs of } \mathrm{Q} .
\end{aligned}
$$

All functions are considered continuous. To isolate the effect of cost sharing on demand, we shall assume that only percentage cost shares (c) change. Thus the national price (P) is assumed to be constant.?

Figures 3.1 and 3.2 show graphically the derivation of demand for shoreline protection as a function of cost sharing. ${ }^{2}$ An indifference curve (IC) represents combinations of $M$ and $Q$ to which the local group is indifferent. For higher levels of $M$ and $Q$, the local group achieves higher levels of satisfaction as represented by $\mathrm{IC}_{3}$ and $\mathrm{IC}_{2}$ being located up and to the right in Figure 3.1. The slopes of these indifference curves represent the marginal rate of substitution (trade-off) of $M$ for $Q$ that the local group is willing to make, based on that group's judgment of the value of benefits from extra units of $M$ and $Q$. These indifference curves are derived from the welfare function in equation 3.1.

The functions $\mathrm{L}\left(\mathrm{C}_{1}\right), \mathrm{L}\left(\mathrm{C}_{2}\right)$, and $\mathrm{L}\left(\mathrm{C}_{3}\right)$ represent the local budget constraints for different cost shares $c_{1}, c_{2}$, and $c_{3}$, where $c_{1}>C_{2}>c_{3}$. The slope of the budget constraints is equal to the ratio of the local price (c - P) of Q over the price of the other goods (M). If the price of $M$ remains constant and the local cost share of $Q$ diminishes, the budget constraint pivots at point $L$ and intersects the horizontal $Q$ axis at points farther to the right. The points of tangency between the indifference curves and the budget constraints indicate the optimal combinations. Hence, as the local cost share decreases from' $\mathrm{c}_{1}$ to $\mathrm{c}_{2}$ to $\mathrm{c}_{3}$, the absolute local price per unit of $Q$ decreases, and the local group will increase its purchases from $Q_{1}$ to $Q_{2}$ to $Q_{3}$ respectively, as shown in Figure 3.2. Thus, the local demand for shoreline protection, other things equal, is shown graphically to depend inversely upon the percentage cost share paid by the local interests.

If the sole purpose of cost sharing for shoreline protection were to encourage local interests to seek more protection, then it follows from this analysis that reducing the local cost share would serve that purpose. But since we know that the Federal budget is also limited and that there are other water projects and nonwater projects competing for scarce Federal funds, there is no basis on national efficiency and equity grounds for lowering local cost shares just to encourage local interests to demand more and larger shoreline protection projects.

The demand analysis is significant for this study in that it shows that local interests acting on rational economic grounds will be affected by the local percentage cost share. Thus cost-sharing policy has the potential to be used as a tool to induce local behavior that will result in nationally efficient projects.

${ }^{1}$ This assumption is made for convenience of illustration. Even if the national price were allowed to vary, it is unlikely that in practice the purchase of extra units of shoreline protection would increase the national price sufficiently to have a dampening effect on local quantity demanded. Thus the local demand curve would probably still be downward sloping. purpose.

${ }^{2}$ This derivation technique could be applied in deriving demand for any project 


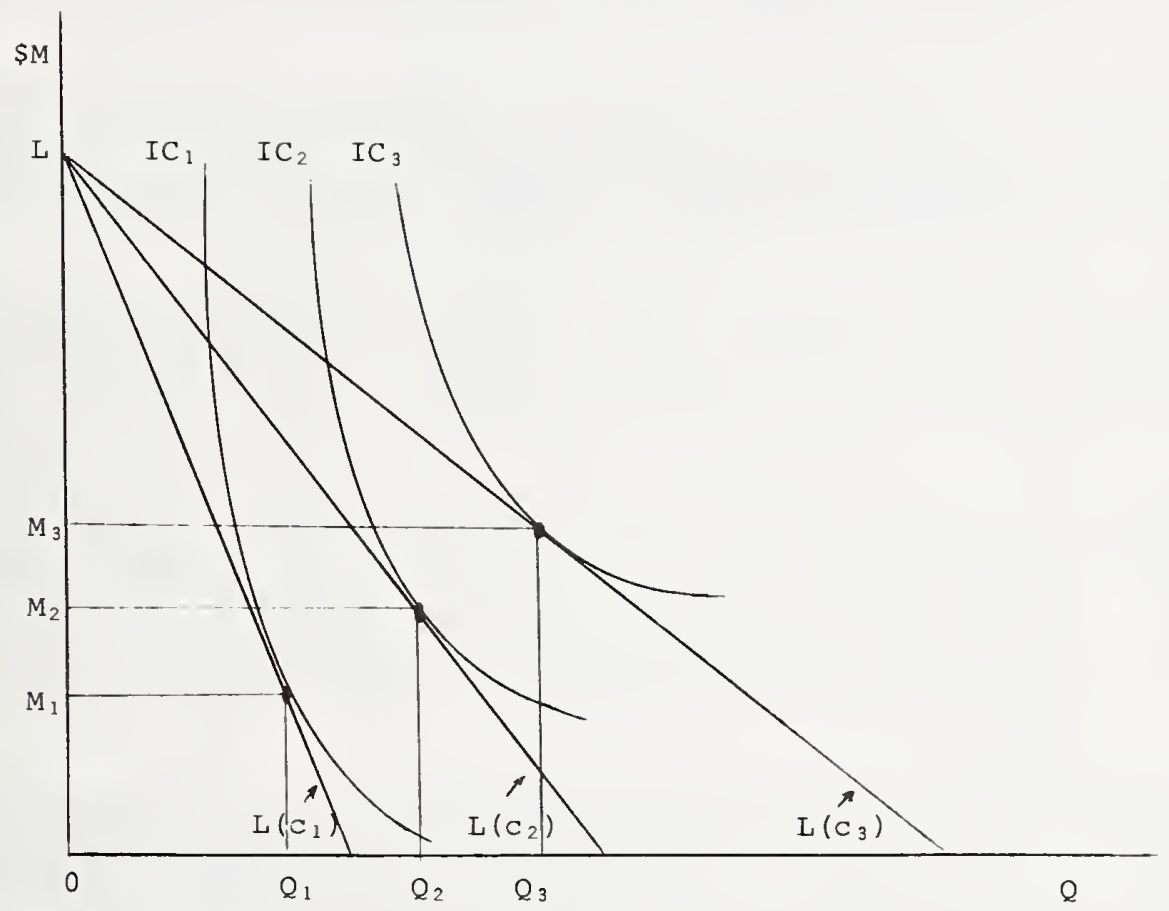

Figure 3.1 -- Indifference Curves and Budget Constraints

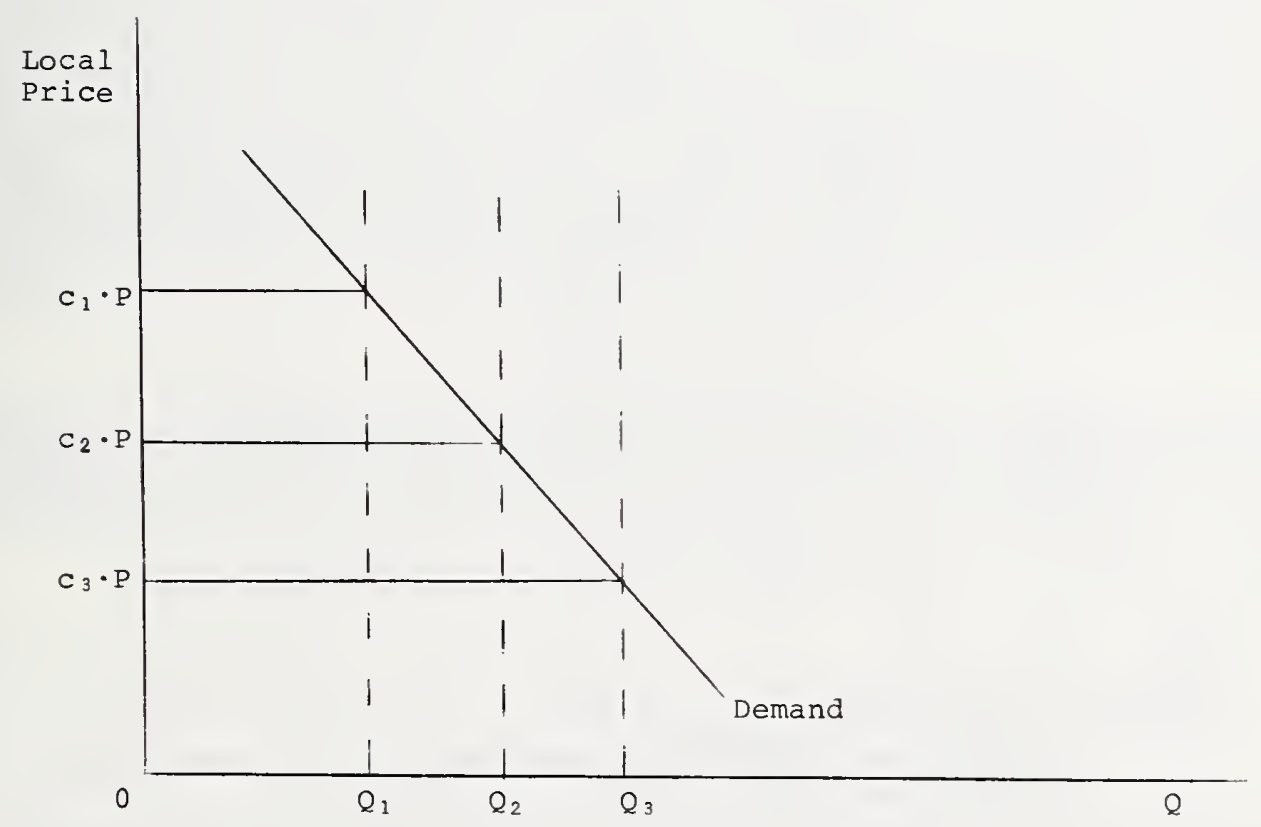

Figure 3.2 -- Demand for Shoreline Protection 


\subsection{Necessary Conditions for Efficiency and Optimality}

This section derives the necessary conditions that cost sharing rules must satisfy in order to encourage local interests to select and support those projects that are most efficient with respect to national economic efficiency, or in the case of multiobjectives, that are optimal from the national viewpoint.

Traditionally, in the techical economic evaluation of a project, the benefits and costs of alternative projects are compared to determine which project maximizes net national benefits. The planning objective of the shoreline protection program under this type of evaluation scheme is the maximization of national income, or alternatively, what is called in the water literature, maximizing national economic development. This is traditionally called an efficiency objective.

This chapter treats cost sharing in its incentive effects not only from the standpoint of the efficiency objective, however, but also from the standpoint of nonefficiency objectives, such as environmental quality. In this paper the "best" project from the standpoint of satisfying multiobjectives will be called the optimal project.

The following terminology is used in the model. Individual goals of the shoreline protection program such as beach erosion control and hurricane protection are called project purposes. A project may comprise one or more purposes. Project benefits are measured as the increase in value of goods (e.g., boardwalk and housing developments) and services (e.g., recreation experience) available to the nation, net of associated or induced costs, that results from having a project as compared to not having it. These benefits may accrue locally or be widespread. Purpose benefits represent the change in value of goods and services that results from having that purpose as compared to not having it.

Project costs include the total costs of project construction, interest, and of operation, maintenance, and replacement. Purpose costs include that part of project costs allocated to a given purpose. Project and purpose net benefits equal the difference between benefits and cost for a project or purpose, respectively. Purpose output, of which benefits and costs are a function, refers to the units of physical output (reduction in number of houses lost or iricrease in recreation user days) provided by the purpose.

The model makes the following assumptions. The Federal agency (e.g., the Corps) and a nonfederal composite of local governments, state governments, shoreline districts, and other local sponsors share the costs of a project providing shoreline protection. The Federal agency and the local faction may apply different criteria for evaluating the project. Local groups would be expected to be most interested in benefits that accrue locally, and the Federal agency must consider benefits that accrue nationally, i.e., benefits that are widespread as well as local. Local interests and the nation as a whole are assumed to have downward sloping demand functions for project outputs. That is, the higher its respective cost share, other things being equal, the less output a faction will demand. Finally, the production function for each purpose output is assumed to be characterized, at least after an initial range, by diminishing marginal returns to successive units of a given input.

\subsubsection{Technique}

Appendix A describes the many engineering and management techniques that can be used for reducing the damages caused by shoreline erosion. The purpose of this section is to derive that cost sharing rule which will encourage local interests to select the combination of techniques for a given project that is least costly to society.

A necessary condition for least-cost production to the nation is that

$$
\frac{\partial Q}{\partial \mathrm{T}_{1}} / \frac{\partial \mathrm{Q}}{\partial \mathrm{T}_{2}}=\frac{\mathrm{P}_{1}}{\mathrm{P}_{2}}
$$

where $Q=$ units of output,

$\mathrm{T}_{1}, \mathrm{~T}_{2}=$ are units of techniques

$\mathrm{T}_{1}$ and $\mathrm{T}_{2}$, which can be management and/or engineering techniques, and

$\mathrm{P}_{1}, \mathrm{P}_{2}=$ national cost or price per units of techniques $\mathrm{T}_{1}$ and $\mathrm{T}_{2} \cdot{ }^{1}$

\footnotetext{
${ }^{2} \mathrm{P}_{1}$ and $\mathrm{P}_{2}$ are assumed to be constant in the relevant range of demand.
} 
This necessary condition is derived as follows. Assume that benefits to the nation (B) from shoreline protection are a function of $Q$ and that $Q=Q\left(T_{1}, T_{2}\right)$. Assume further that the nation has some budget constraint (S). To $E j$ nd the maximum of $B\left[Q\left(T_{1}, T_{2}\right)\right]$ subject to the constraint that $S=P_{1} T_{1}+P_{2} T_{2}$, we make the problem unconstrained by use of the Lagrange multiplier $(\lambda)$ and maximize the new expression

$$
W=B(Q)+\lambda\left(S-P_{1} T_{1}-P_{2} T_{2}\right) \text {, }
$$

where $W$ now is a function of $T_{1}, T_{2}$, and $\lambda$.

A necessary condition for optimization is that the partial derivatives of $W$ with respect to each variable must equal zero. By doing this for the two techniques we have

$$
\begin{aligned}
& \frac{\partial W}{\partial T_{1}}=\frac{\partial B}{\partial Q} \cdot \frac{\partial Q}{\partial T_{1}}+\lambda\left(-P_{1}\right)=0, \text { and } \\
& \frac{\partial W}{\partial T_{2}}=\frac{\partial B}{\partial Q} \cdot \frac{\partial Q}{\partial T_{2}}+\lambda\left(-P_{2}\right)=0 .
\end{aligned}
$$

Placing the negative terms to the right side of the equations and dividing the first expression by the second yield

$$
\frac{\partial B}{\partial Q} \cdot \frac{\partial Q}{\partial T_{1}} / \frac{\partial B}{\partial Q} \cdot \frac{\partial Q}{\partial T_{2}}=\frac{\lambda P_{1}}{\lambda P_{2}} .
$$

Cancellation results in the condition to be demonstrated,

$$
\frac{\partial Q}{\partial T_{1}} / \frac{\partial Q}{\partial T_{2}}=\frac{P_{1}}{P_{2}}
$$

This means simply that each technique will be used up to that level at which the extra output realized per extra dollar spent is equal for the two techniques. The Federal agency, as an agent for society as a whole, is supposed to select techniques according to this least-cost principle.

To illustrate how a local group will choose among techniques, we examine that group's behavior under the assumption that it attempts to maximize local benefits subject to a local budget constraint. A necessary condition for the least-cost production for local interests is that

$$
\frac{\partial Q}{\partial \mathrm{T}_{1}} / \frac{\partial Q}{\partial \mathrm{T}_{2}}=\frac{\mathrm{C}_{1} \mathrm{P}_{1}}{\mathrm{C}_{2} \mathrm{P}_{2}} \text {, }
$$

where $c_{1}, c_{2}=$ local cost shares (proportions) of techniques $\mathrm{T}_{1}$ and $\mathrm{T}_{2}$ respectively. This condition if derived as follows. ' Assume that local benefits ( ${ }^{L}$ ) are a function of $Q$ and that local interests have some budget constraint L. To find the maximum of $\mathrm{B}_{\mathrm{L}}\left[\mathrm{Q}\left(\mathrm{T}_{1}, \mathrm{~T}_{2}\right)\right]$ subject to the constraint that $\mathrm{L}=\mathrm{c}_{1} \mathrm{P}_{1} \mathrm{~T}_{1}+\mathrm{c}_{2} \mathrm{P}_{2} \mathrm{~T}_{2}$, we can make the problem unconstrained by use of the Lagrange multiplier and maximize the expression

$$
V=B_{L}(Q)+\lambda\left(L-C_{1} P_{1} T_{1}-c_{2} P_{2} T_{2}\right)
$$

where $\mathrm{V}$ is now a function of $\mathrm{T}_{1}, \mathrm{~T}_{2}, \lambda, \mathrm{C}_{1}$, and $\mathrm{c}_{2}$.

By setting the partial derivatives of $\mathrm{V}$ with respect to $\mathrm{T}_{1}$ and $\mathrm{T}_{2}$ equal to $\mathrm{zero}$, we obtain

$$
\begin{aligned}
& \frac{\partial V}{\partial T_{1}}=\frac{\partial B_{L}}{\partial Q} \cdot \frac{\partial Q}{\partial T_{1}}+\lambda\left(-c_{1} P_{1}\right)=0 \text { and } \\
& \frac{\partial V}{\partial T_{2}}=\frac{\partial B}{\partial Q} \cdot \frac{\partial Q}{\partial T_{2}}+\lambda\left(-c_{2} P_{2}\right)=0 .
\end{aligned}
$$

${ }^{1}$ This derivation of the necessary conditions for inducing local interests to choose the least-cost technique for society is similar to that which appears in Marshall, "Economic Efficiency Implications of Federal-Local Cost Sharing in Water Resource Development," pp. 674-675. 
Placing the negative terms to the right side of the equations and dividing the first expression by the second yield

$$
\frac{\partial B_{L}}{\partial Q} \cdot \frac{\partial Q}{\partial T_{1}} / \frac{\partial B_{L}}{\partial Q} \cdot \frac{\partial Q}{\partial T_{2}}=\frac{\lambda c_{1} P_{1}}{\lambda c_{2} P_{2}} .
$$

Cancellation results in the condition to be demonstrated,

$$
\frac{\partial Q}{\partial \mathrm{T}_{1}} / \frac{\partial Q}{\partial \mathrm{T}_{2}}=\frac{\mathrm{C}_{1} \mathrm{P}_{1}}{\mathrm{C}_{2} \mathrm{P}_{2}}
$$

Note that identical cost shares $\left(c_{1}=c_{2}\right)$ must apply to each technique if cost sharing is to induce local interests to select the nationally efficient combination of techniques. If $\mathrm{C}_{1}>\mathrm{c}_{2}$, local interests will be biased by cost sharing to choose less of $\mathrm{T}_{1}$ and more of $\mathrm{T}_{2}$ then is nationally efficient. If $\mathrm{c}_{2}>\mathrm{c}_{1}$, they will be biased to choose less of $T_{2}$ and more of $T_{1}$ than is nationally efficient. Only when $c_{1}=c_{2}$ does the local maximizing condition (3.8) become equivalent to the least-cost condition for society (3.3). This condition for equal cost shares can be extended to as many techniques as are reasonable substitutes for providing a given level of output.

It is possible that the efficient level of output (scale) will not be chosen, however, when $c_{1}=c_{2}$. The choice of scale and the choice of techniques are often executed independently in water projects. Yet given some scale of Q, local interests are encouraged to choose the nationally least-cost combination of techniques by making $\mathrm{c}_{1}=\mathrm{c}_{2}$. (Section 3.3.2 treats the problem of efficient scale in detail.)

Figure 3.3 provides an alternative illustration of the cost-sharing condition for efficient techniques. Assume that $Q_{1}$ level of shoreline protection can be produced with those combinations of units of $T_{1}$ and $T_{2}$ indicated by the three dots $a$, $b$, and $c$. Assume further that the local share of benefits is the same for output $Q_{1}$, whether it is provided by combinations $a, b$, or $c$. Isocost $L$ depicts the locus of quantity combinations of $\mathrm{T}_{1}$ and $\mathrm{T}_{2}$ that local interests can afford with budget constraint $\mathrm{L}$ and Federal cost sharing. Isocosts $S_{1}$ and $S_{2}$ depict the locus of quantity combinations of $T_{1}$ and $T_{2}$ that the nation can afford with budget constraints $S_{1}$ and $S_{2}\left(S_{2}>S_{1}\right)$. The local and Federal isocosts are not parallel because $\mathrm{c}_{1}<\mathrm{c}_{2}$. That is, the slope of $\mathrm{L}, \mathrm{C}_{2} \mathrm{P}_{2} / \mathrm{C}_{1} \mathrm{P}_{1}$, is steeper than'the slope of $\mathrm{P}_{2} / \mathrm{P}_{1}$ of $\mathrm{S}_{1}$ and $\mathrm{S}_{2}$. Because the local cost share of $\mathrm{T}_{2}$ is higher than the share of $\mathrm{T}_{1}$, local interests will choose a production process using more $T_{1}$ than will the Federal agency seeking national efficiency.

Figure 3.3 shows that local interests can afford $Q_{1}$ level of output with budget $I$ only if technique $T_{1}$ is used exclusively. The cost to the nation of producing $Q_{1}$ with technique $\mathrm{T}_{1}$ is $\mathrm{S}_{2}$. Yet society can realize $Q_{1}$ at a lower cost $S_{1}$ by using only technique $\mathrm{T}_{2}$. The local faction will select the same technique(s) as the Federal faction for producing $Q_{1}$ only when the slopes of both factions' budget constraints are the same. If the local budget is large enough to make L coincident with $S_{1}$ under the condition that $c_{1}=c_{2}$, then both the Federal agency and the local faction will choose to produce with technique $T_{2}$ exclusively. The savings to the nation (net efficiency gain) from producing $Q_{1}$ with $T_{2}$ instead of $T_{1}$ would be the difference in budgets $S_{2}$ and $S_{1}$.
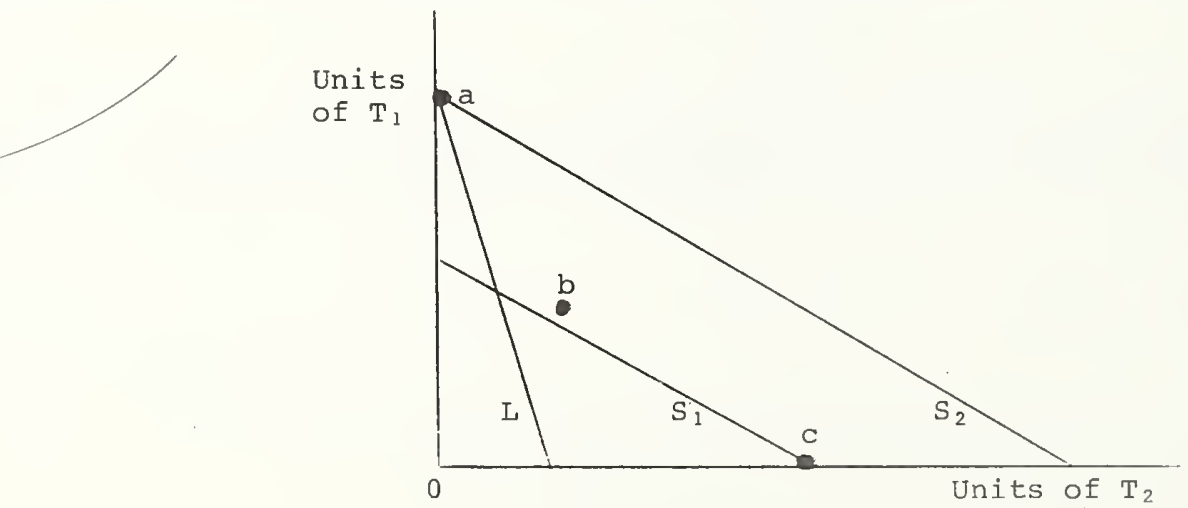

Figure $3.3-$ - Cost Share for Efficient Technique(s) 
The analyses above show that an equal percentage cost share for all techniques of providing shoreline protection is necessary on national efficiency grounds. An equal percentage policy is also necessary where the project is designed to maximize the net benefits from multiobjectives. For example, if cost sharing were to be selected as a way of redistributing income for meeting the objective of regional development, the most efficient redistribution would be effected by lowering local cost shares to an equal percentage for all techniques of production rather than just lowering them for some of the techniques.

The efficiency implications of existing cost-sharing rules for different techniques of shoreline protection will be evaluated in Chapter 4 .

\section{3.2 Scale}

The purpose of this section is to derive a cost-sharing rule which will encourage local interests to select the nationally efficient or optimal project size. The rule to be derived is called the Association Rule (AR). ' Assume the following:

$$
\begin{array}{rlrl}
\mathrm{B} & =\mathrm{B}(\mathrm{Q}) & \mathrm{C}=\mathrm{C}(\mathrm{Q}) \\
\mathrm{B}_{\mathrm{F}}=\mathrm{B}-\mathrm{B}_{\mathrm{L}} & \mathrm{C}=\mathrm{C}_{\mathrm{L}}+\mathrm{C}_{\mathrm{F}} \\
\mathrm{b} & =\frac{\mathrm{dB} L}{\mathrm{dQ}} / \frac{\mathrm{dB}}{\mathrm{dQ}}(3.13) & \mathrm{C} & =\frac{\mathrm{dC}_{L}}{\mathrm{dQ}} / \frac{\mathrm{dC}}{\mathrm{dQ}}
\end{array}
$$

where $\mathrm{B}=$ total benefits accruing to the nation,

$\mathrm{B}_{\mathrm{F}}=$ widespread benefits not assignable to local interests,

$\mathrm{B}_{\mathrm{L}}=$ benefits accruing to local interests,

$\mathrm{b}=$ proportion of $\mathrm{B}$ accruing to local interests at the margin,

$\mathrm{C}=$ total costs accruing to the nation,

$\mathrm{C}_{\mathrm{L}}=$ costs borne by local interests,

$\mathrm{C}_{\mathrm{F}}=$ costs borne by the Federal government, and

$\mathrm{c}=$ proportion of $\mathrm{C}$ paid by local interests at the margin.

For national economic efficiency, a project purpose must be built to that scale where net national benefits are maximized. Assuming continuous and smooth functions, this condition is

$$
\frac{d B}{d Q}=\frac{d C^{2}}{d Q} .
$$

The last increment in scale adds benefits just equal to the marginal costs of production. If a project is underbuilt or overbuilt with respect to the scale that is nationally efficient, then too few or too many resources respectively have been allocated to that project purpose.

To maximize their net benefits, local interests will choose, if possible, that scale where

$$
\frac{\mathrm{dB}_{L}}{\mathrm{dQ}}=\frac{\mathrm{dC}_{L}}{\mathrm{dQ}} .
$$

Local interests cannot gain net benefits by altering the size of the project when this condition is satisfied.

'This derivation of the AR comes from Marshall and Broussalian, Federal Cost-Sharing Policies for Water Resources, pp. 58-65, and Marshall, "Economic Efficiency Implications of Federal-Local Cost Sharing in water Resource Development, pp. 675-677.

${ }^{2}$ For a derivation of this condition and of the condition for maximizing efficiency in the presence of a budget constraint, see Stephen A. Marglin, "Objectives of WaterResource Development: A General Statement," Design of Water Resource Systems, Maass, et. al. (Cambridge, Massachusetts: Harvard University Press, 1962), pp. 31-36. 
From equation (3.16) and equations ( 3.13 and (3.14), we obtain

$$
\begin{array}{r}
\frac{d B_{L}}{d Q}=b \cdot \frac{d B}{d Q} \\
\text { and } \frac{d C_{L}}{d Q}=c \cdot \frac{d C}{d Q}
\end{array}
$$

By appropriate substitution into equation (3.16), we obtain the following condition:

$$
\mathrm{b} \cdot \frac{\mathrm{dB}}{\mathrm{dQ}}=\mathrm{c} \cdot \frac{\mathrm{dC}}{\mathrm{dQ}} \cdot
$$

This maximization condition for local interests shows, by comparing it with condition (3.15), that the scale desired by local interests will equal that picked by the Federal agency only if $b=c$. This condition, i.e., that costs are shared in the same proportion as benefits at the margin, is called the Association Rule (AR). If $b>c$, local interests will choose a scale larger than the nationally efficient level and $\mathrm{dB} / \mathrm{dQ}<\mathrm{dC} / \mathrm{dQ}$. If $\mathrm{b}<\mathrm{c}$, that will choose a scale smaller than the nationally efficient level and $\mathrm{dB} / \mathrm{dQ}>\mathrm{dC} / \mathrm{dQ}$.

Figure 3.4 illustrates the AR graphically. Demand functions MNB and MLB represent the willingness-to-pay for shoreline protection by the nation and by local interests respectively." The downward slopes depict diminishing marginal benefits to each faction for extra units of protection output. Assume for illustrative purposes that 75\% of MNB accrues locally, as measured by MLB. Assume further than the marginal national cost curve, MNC, represents the least-cost combinations of techniques for providing each level of output.

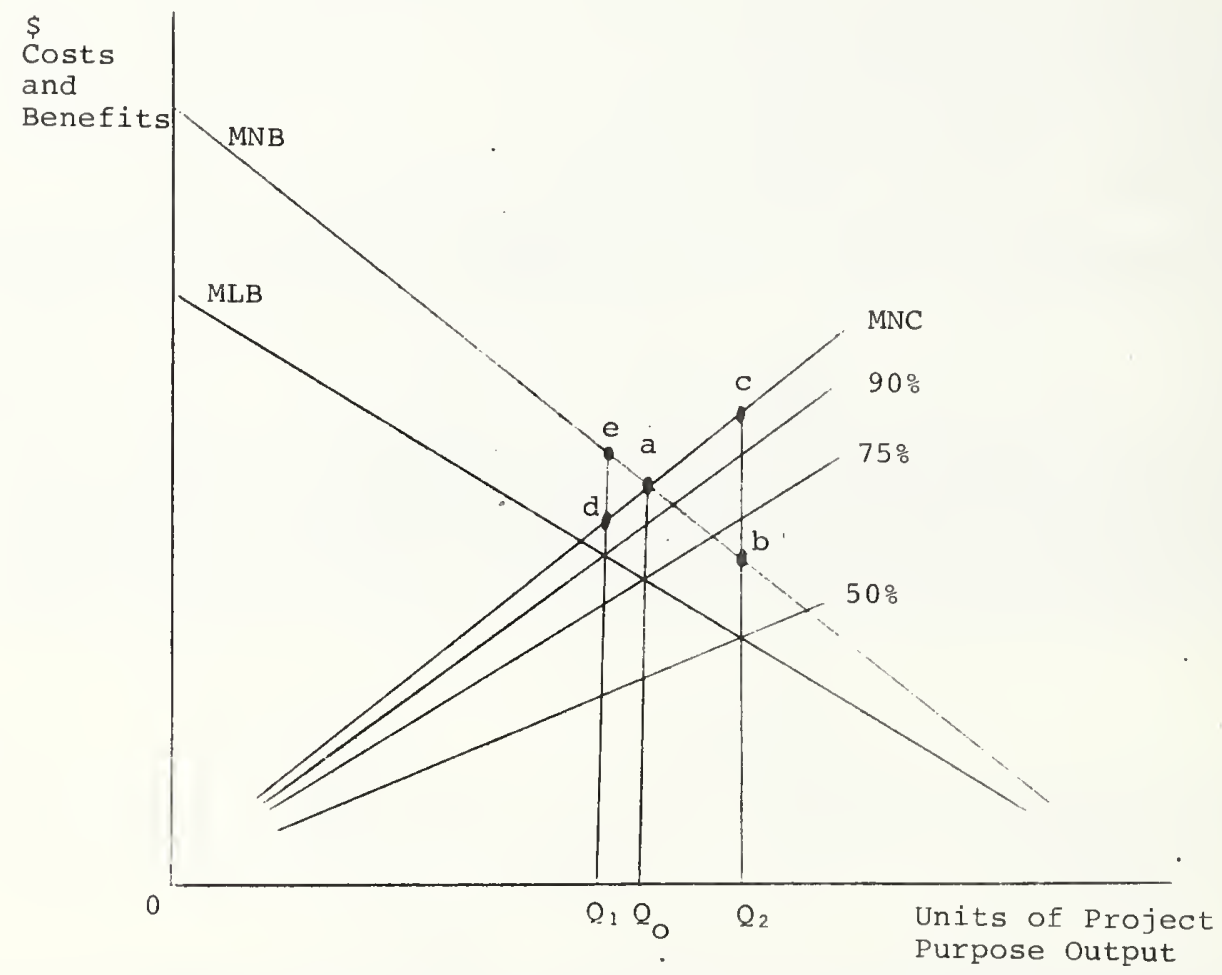

Figure 3.4 -- Cost Share for Efficient Scale

${ }^{1} \mathrm{MNB}$ and $\mathrm{MLB}$ are respectively $\frac{\mathrm{dB}}{\mathrm{dQ}}$ and $\frac{\mathrm{dB}_{\mathrm{L}}}{\mathrm{dQ}}$. 
Net national benefits are maximized at $Q_{0}$ because $d B / d Q=d C / d Q, i . e ., M N B=M N C$. Local interests will be encouraged to select up to $Q_{0}$ only when they pay a cost share of $75 \%$, which makes $\mathrm{dB}_{\mathrm{L}} / \mathrm{dQ}=\mathrm{dC}_{\mathrm{L}} / \mathrm{dQ}$ at $\mathrm{Q}_{0}$ (i.e., MLB $=.75 \mathrm{MNC}=\mathrm{MLC}$ ). If local

interests are charged $50 \%$ of costs, they will choose up to $Q_{2}$. The national efficiency loss would amount to abc if the project were built to this scale. A 90 . local cost share would induce local interests to choose up to $Q_{1}$. If the project were built to this scale, an efficiency loss of aed would result, equal to the foregone amount by which extra national benefits would have exceeded extra national costs up to $Q_{0}$.

The mathematical and graphical analyses show that the AR meets the necessary condition for encouraging local interests to choose the nationally efficient project scale. However, two types of data must be available for applying the AR. The first is local benefits information, which would be available if regional benefits were computed for a regional development objective. The second is marginal cost data by purpose. For a single-purpose beach erosion control project or hurricane protection project, this is available under current procedures. Where a multiple-purpose beach erosion control and hurricane protection project is involved, marginal costs are not allocated by purpose, but the AR can still be applied to the two purposes as a bundle. Application of the AR is not difficult in shoreline protection because outputs are similar among purposes and the beneficiaries are essentially the same for the bundle of purposes. Even for multiple-purpose projects with such diverse purposes as recreation and flood protection, the AR can still be applied.

So far in our discussion of scale we have assumed that the single objective of shoreline development is national economic development, where we attempt to maximize net efficiency benefits. Now we broaden our perspective to consider the nonefficiency objective of environmental quality.

Assuming the Federal agency has found a method of determining the optimal shoreline protection project with respect to multiobjectives, ${ }^{2}$ it should plan each purpose to the scale at which MNB = MNC, where benefits and costs represent all types of benefits and costs with respect to each of the multiobjectives. Once the optimal scale is determined, the AR can be applied by purpose or bundle of purposes to induce local interests to select that scale.

The following chapter examines the actual percentage cost shares that have been incurred by local and Federal groups for shoreline protection. Differences in percentage cost shares are displayed and evaluated for their efficiency impacts.

${ }^{1}$ For a description of the application of the AR to a bundle of purposes in multiple-purpose projects, see Marshall and Broussalian, Federal Cost-Sharing Policies for Water Resources, pp. 65-71.

${ }^{2}$ For one approach to determining the optimal water project with respect to multiobjectives, see Marshall and Broussalian, Federal Cost-Sharing Policies for Water Resources, pp. 182-201. 
Tile laws and policies tilat enalle tire Corps to participate in shoreline protection have been discussed, and the cost-sharing rules that govern sizoreline protection have been explained and compared. The previous chapter set out necessary conditions for local cost sharing to induce nationally efficient water projects. The purposes of this chapter are (1) to examine actual cost shares to determine if shares vary in practice among shoreline protection techniques, programs, and within a given slioreline protection program and (2) to evaluate the efficiency impacts of existing cost shariıc rules. Chapter 5 evaluates alternative cost-sharing rules with respect to national efficiency criteria and both alternative and existing rules with respect to equity and administrative feasibility.

\subsection{Differences in Cost Sharing by Technique}

Cost--sllaring rules for shoreline protection are not specified by technique, but by program (Table 2.1) and by ownership and use (Table 2.2). Because specified costsiaring percentages are identical for established engineering techniques, there is no inherent cost-sharing bias that makes local interests select one established technique over another. Tis satisfies the necessary condition derived in chapter 3 for selection of the least-costly technique. For example, since local interests pay the same percentage cost share for dunes as for sroins, they will be induced to pick that alternative which is cheaper for them as well as for the nation. This is in contrast to other water programs such as Corps flood protection, where alternative techniques such as large reservoirs, small reservoirs, levees, and diversion channels require different local cost-sharing percentages, 'thereby biasing local choice in some projects against the nationally efficient technique.

Some variation in the percentage local cost shares may exist within engineering techniques, however, where all $0+M$ is abscrbed by local interests but construction costs are shared to some extent by the corps. Beach erosion control is an example. Here local interests would be induced to select those techniques with relatively low $0+M$ requirements. To eliminate this bias and satisfy the least-cost condition set forth in Chapter 3, all categories of cost (in this case construction and $0+M$ ) would have to be shared in the same percentage.

Cost sharing for Corps projects does differ by technioue when we include among the techniques management or non-structural alternatives such as zoning, subdivision regulation, acquisition of property and relocation, and insurance. In effect, because there is no or little Federal cost-sharing assistance for these techniques, local groups have a built-in bias against them.

One potential efficiency impact of applying engineering techniques exclusively for shoreline protection is that less costly management alternatives may have been overlooked. A second impact is on development. People feel more security with manmade, physical, tangible barriers against the sea. Providing engineering protection thereby increases development in the protected area and raises the damage potential from any storm that surmounts the barriers. Management techniques, on the other hand, restrict development so that it is away from or protected in some way from the sea. The potential asset stock subject to damages is reduced or restricted in growth instead of being stimulated as by engineering techniqus. ${ }^{2}$

\footnotetext{
'Marshall, "Economic Efficiency Implications of Federal-Local Cost Sharing in Water-Resource Development," p. 679.

${ }^{2}$ For a comprehensive discussion of the choice among alternative technqiues for protection against floods, see Gilbert F. White, Human Adjustment to Floods: A Geographical Approach to Flood Problems in the U.S. (Chicago: University of Chicago, 1945), and Gilbert F. White, Choice of Adjustment to Floods, Department of Geography Research Paper No. 39 (Chicago: University of Chicags, 1964).
} 


\subsection{Differences in Cost Sharing by Program}

Given the different cost-sharing rules by program, as outlined in Table 2.1, we would expect to see different actual percentage cost shares incurred by local interests for the different programs. Specifically, we would expect to see higher percentage shares incurred by local interests in heach erosion control projects than in hurricane or emergency protection programs.

Tables 4.1 through 4.6 show local and Federal cost shares by region for single purpose beacil erosion control projects and for multiple-purpose projects which include mostly beach erosion and hurricane protection, with some navigation. To determine actual differences in local cost shares between the beach erosion control program and tine hurricane protection program, we can compare in Table 4.1 through 4.6 , by region and for the nation, percentage cost shares for projects that are authorized and completed, authorized and underway, and authorized but not yet started. For example, for the North Atlantic Region, projects that are "authorized and underway" have a $60 \%$ local cost share for beach erosion control (Table 4.2) and a $44 \%$ local cost share for multiple-purpose projects (Table 4.5). Note that by using cost shares for multiple-purpose projects as a proxy for cost shares for hurricane protection, we are actually biasing the local percentage up; i.e., the beach erosion component in hurricane protection will tend to make local cost shares higher than what they would be otherwise. ' Thus, the $44 \%$ figure is an upper bound, and one would expect the cost-sharing spread between beach erosion control and hurricane protection to be even greater than $16 \%(60 \%-44 \%)$.

Looking at the totals for the nation, authorized and completed beach erosion control projects (Table 4.1) cost local interests about 47\%, whereas hurricane protection (Table 4.4) cost them only 16\%. A complete examination of the tables show that in every region and in total, for projects completed, underway, and not yet started, the local percentage cost share is higher for beach erosion control than for hurricane protection. ${ }^{2}$

Additional data that demonstrate the differences in local percentage cost shares between beaci erosion control and hurricane protection are presented by state in Tables 4.7 and $4.8^{3} \mathrm{All}$ of the described projects were either authorized subsequent to a 1962 Act or modified by it. Table 4.7 shows local and Federal construction costs, in absolute and percentage terms, for 14 multiple-purpose projects, containing hurricane protection and beach erosion control, divided amony 7 states. A proxy for the local cost share for ilurricane protection was taken from these multiple-purpose projects. Local shares averaçed from about $30 \%$ up to $60 \%$ by state, with an overall average taken from all state averages equal to approximately $42 \% .^{4}$ The average $10 c a l$ cost share for just 9 projects, excluding those 5 individual projects in North Carolina, was about $44 \% .^{5}$

'The presence of navigation does not bias the estimate of hurricane protection cost sharing because tine same rule (100\% Federal share of construction and zero percent share of lands, easements, and right-of-way) applies to navigation as to hurricane protection.

2 These figures include land rights but not $O+M$ expenses. Inclusion of $C+M$ costs would give a more complete picture of cost sharing, but, as illustrated in Table 2.1 , $0+M$ costs are normally not shared by the Federal government under either program, so their comparison is not necessary to compare differences.

${ }^{3}$ These tables were computed from Tables I trrouch III in a letter to senator Jacob Javits from Leonard Edelstein, Colonel, Corps of Engineers. The letter is contained in U.S. Congress, Senate, Committee on Public Works, Omnibus Water Resource Authorizations-1970, Hearings, pp. 654-658.

${ }^{4}$ The sum of the percentage local cost shares divided by the number of states equals $41.9 \%$

5 The cost shares for New York by project are not shown in the table. The cost shares for North Carolina by project were not available. 


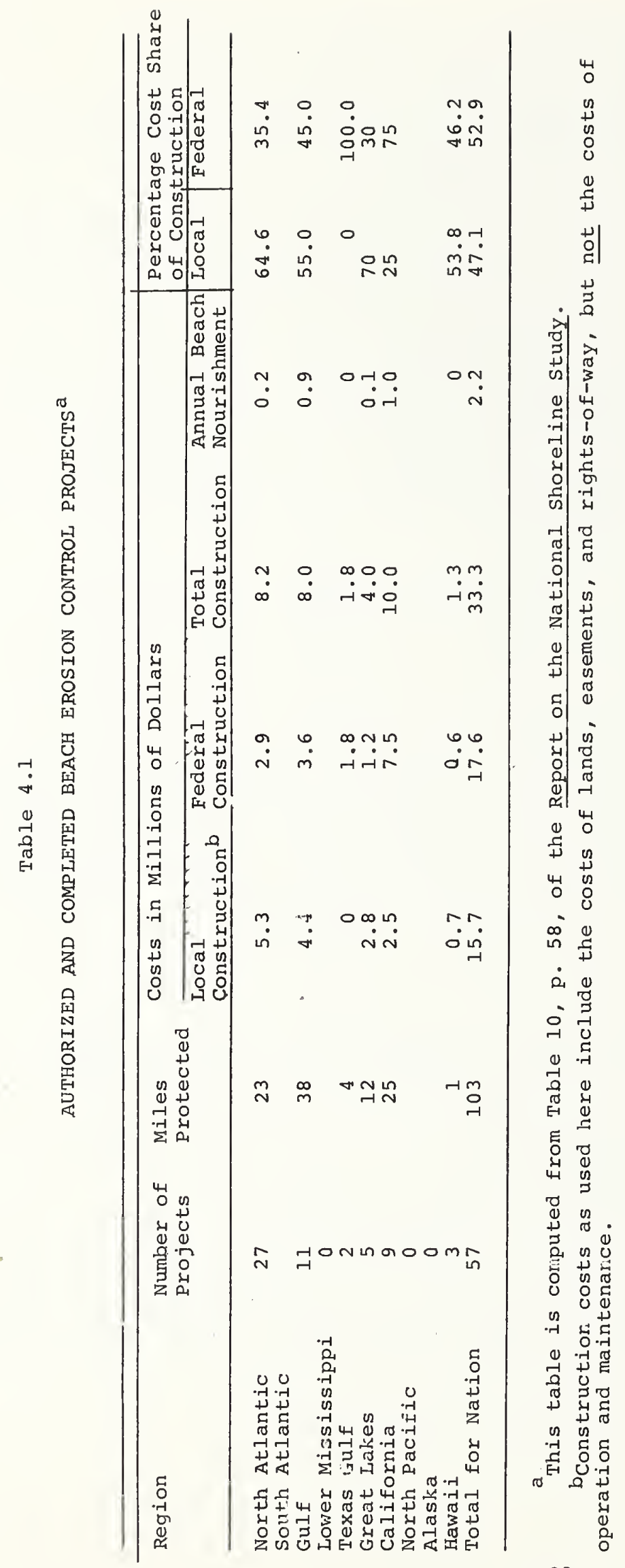




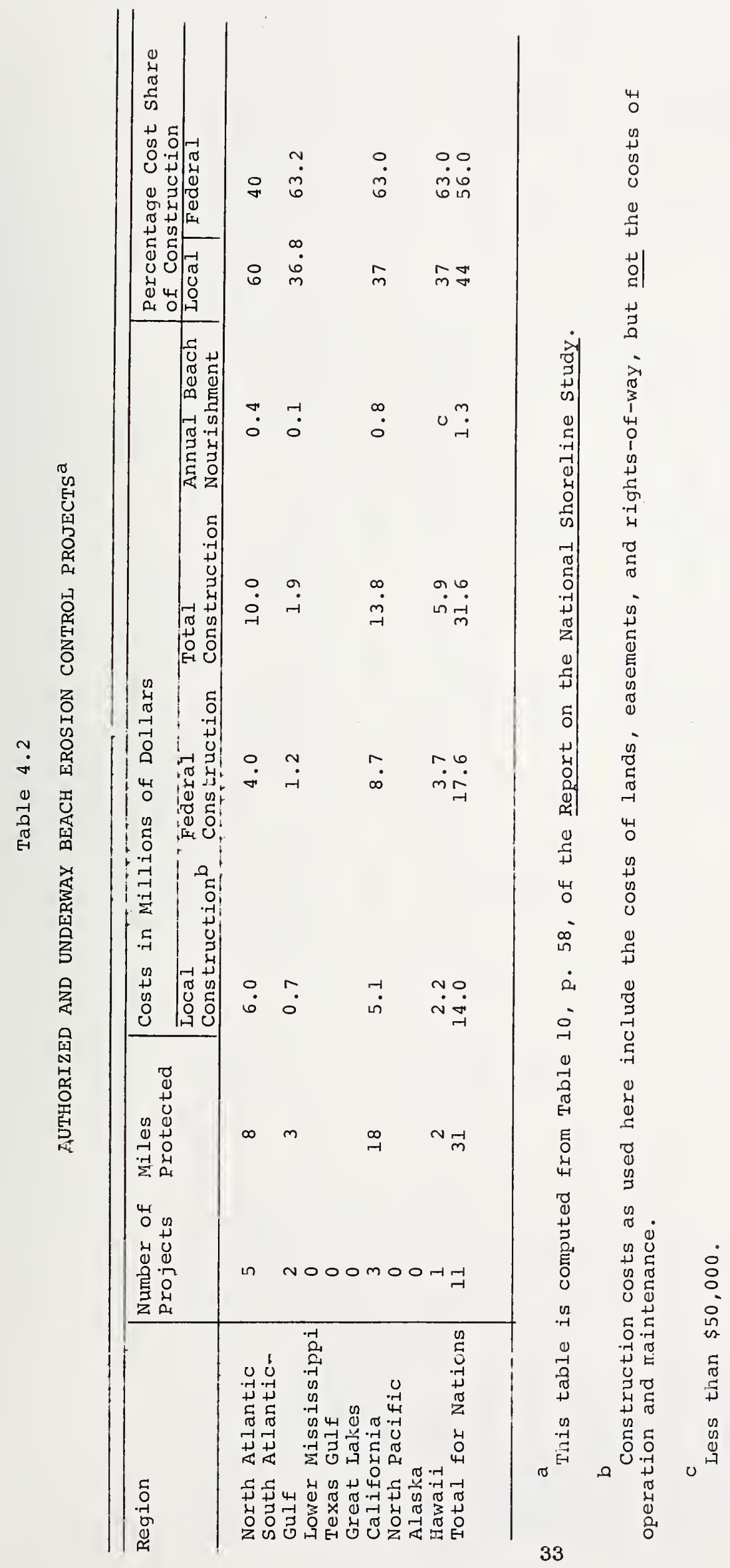




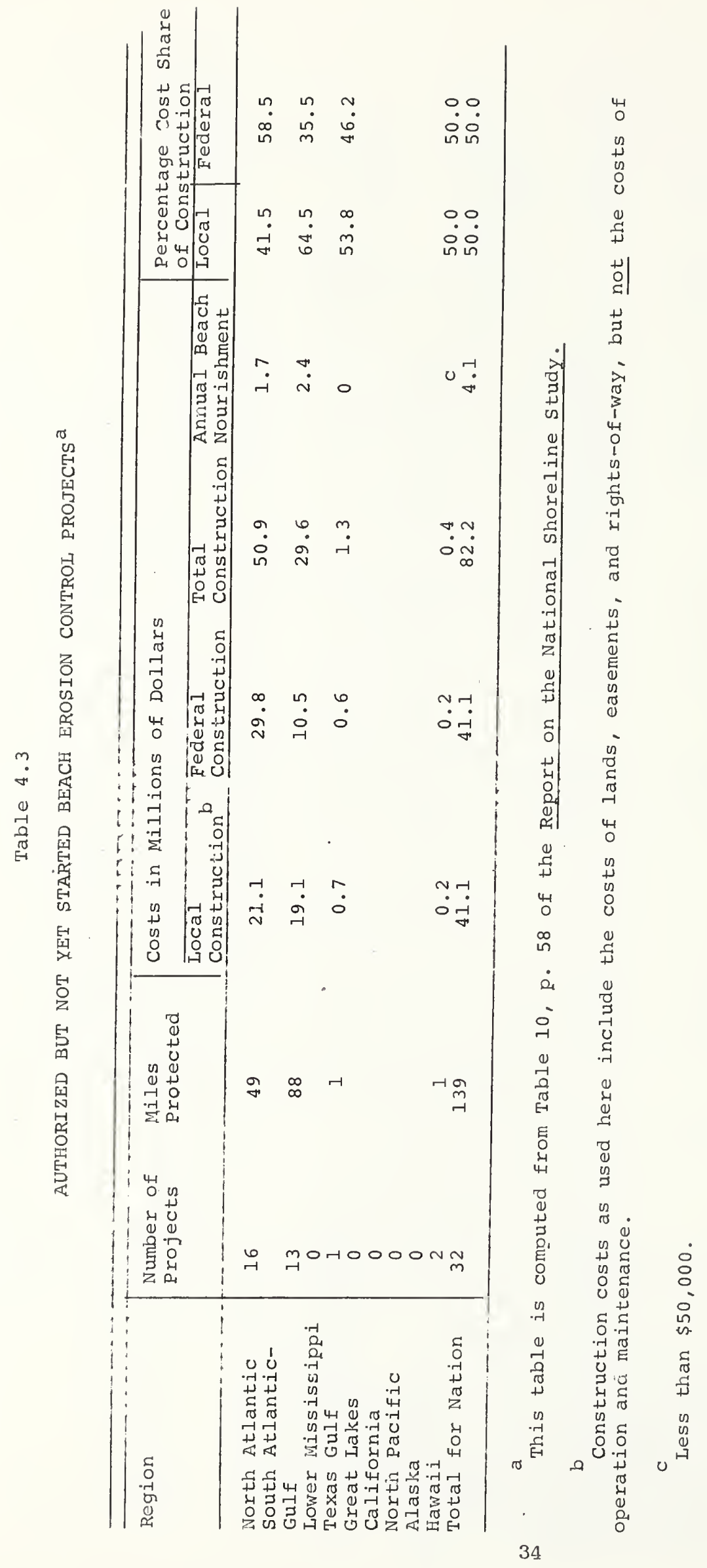




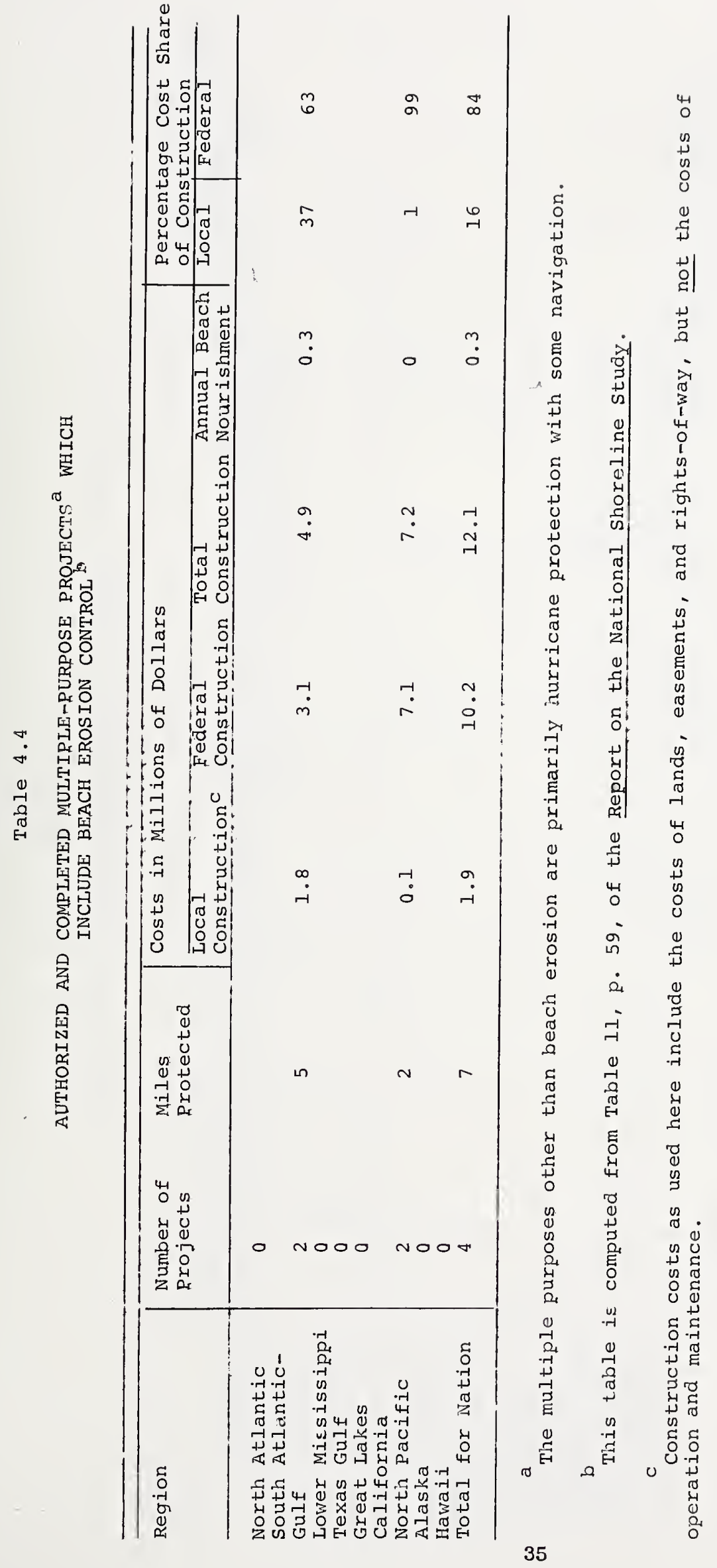




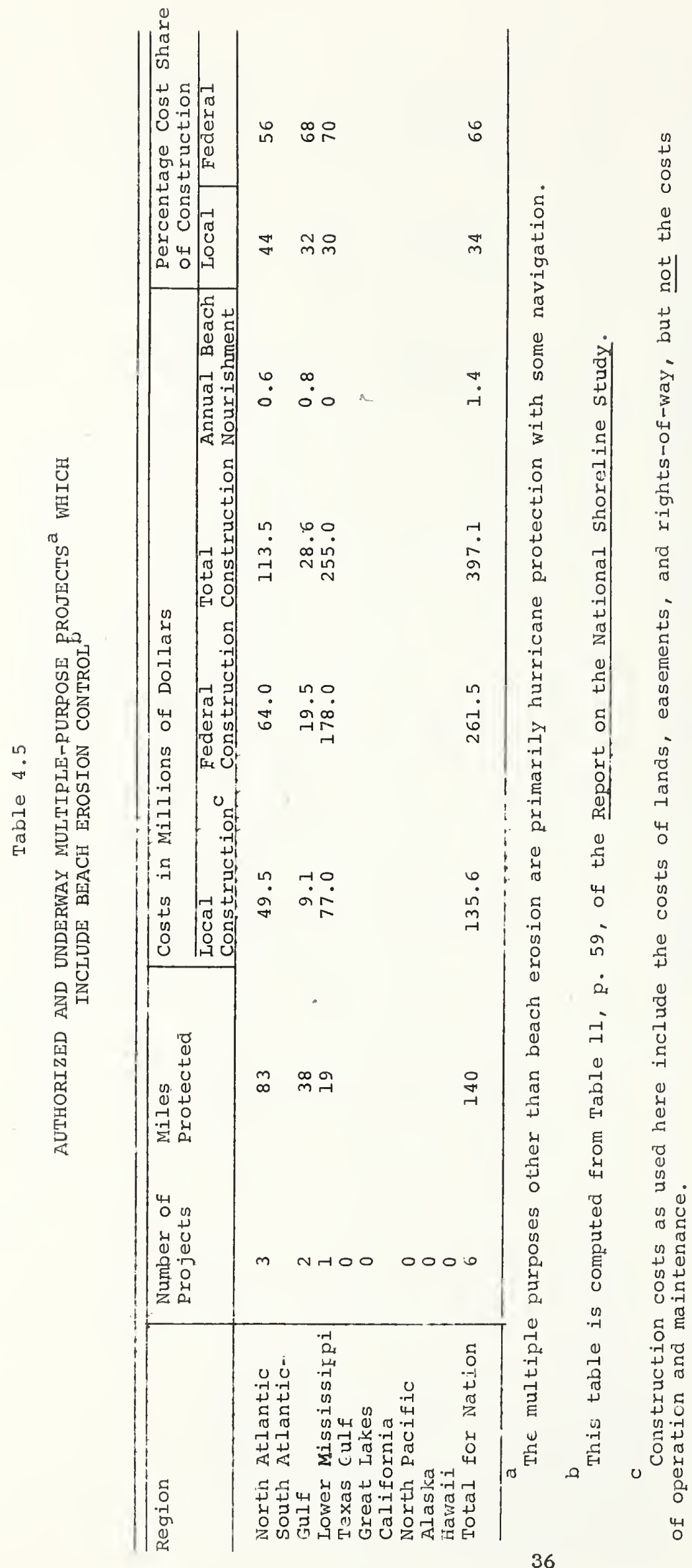




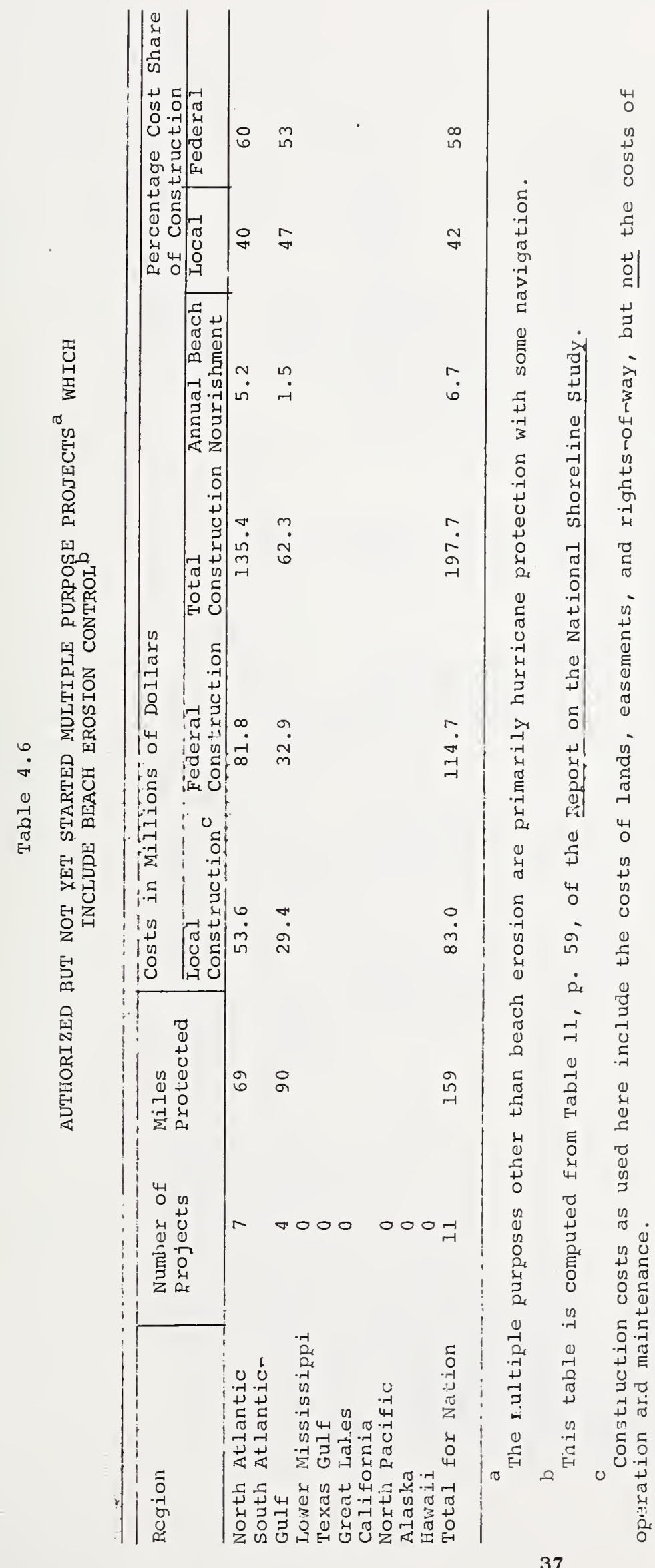




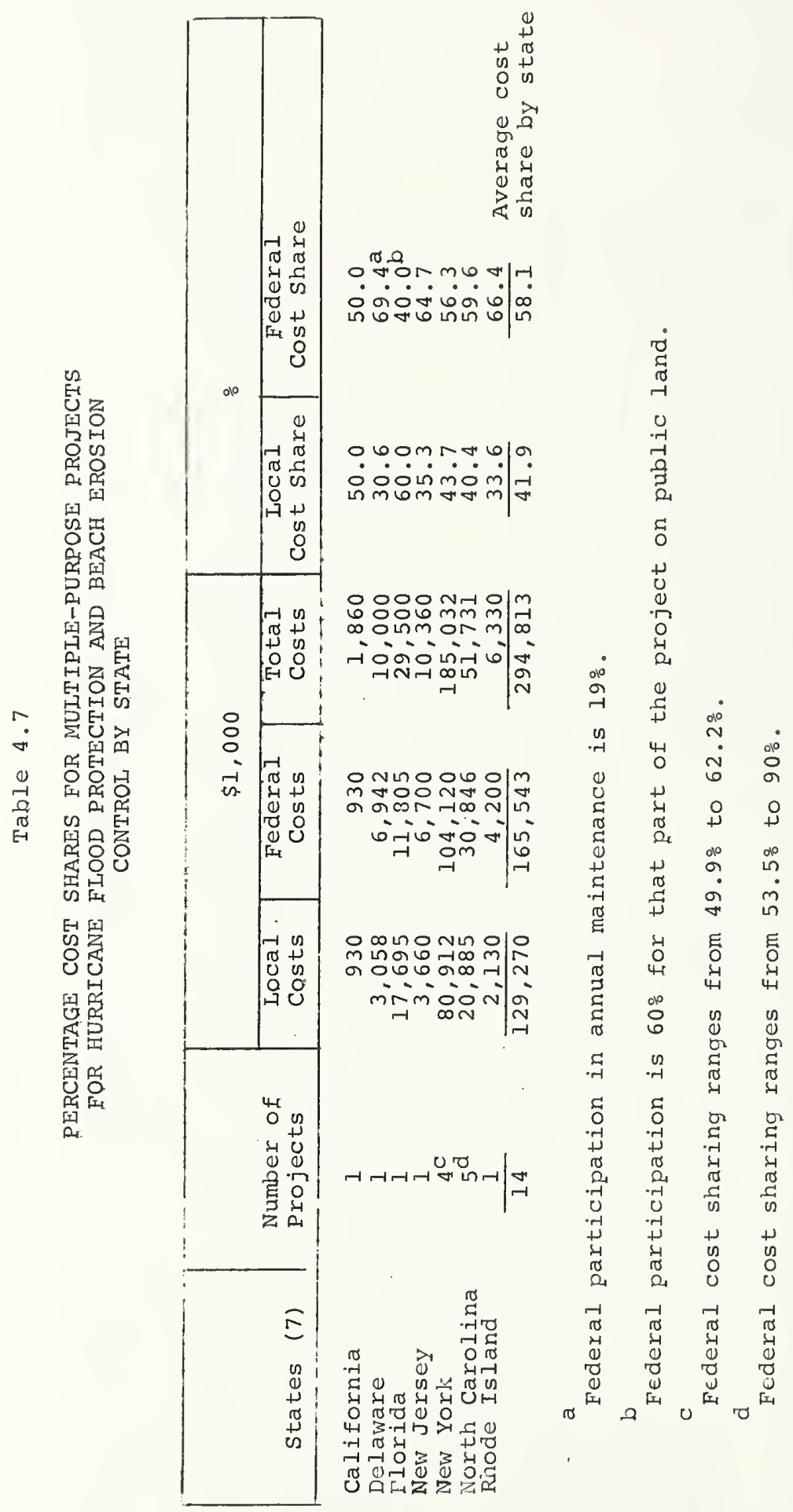




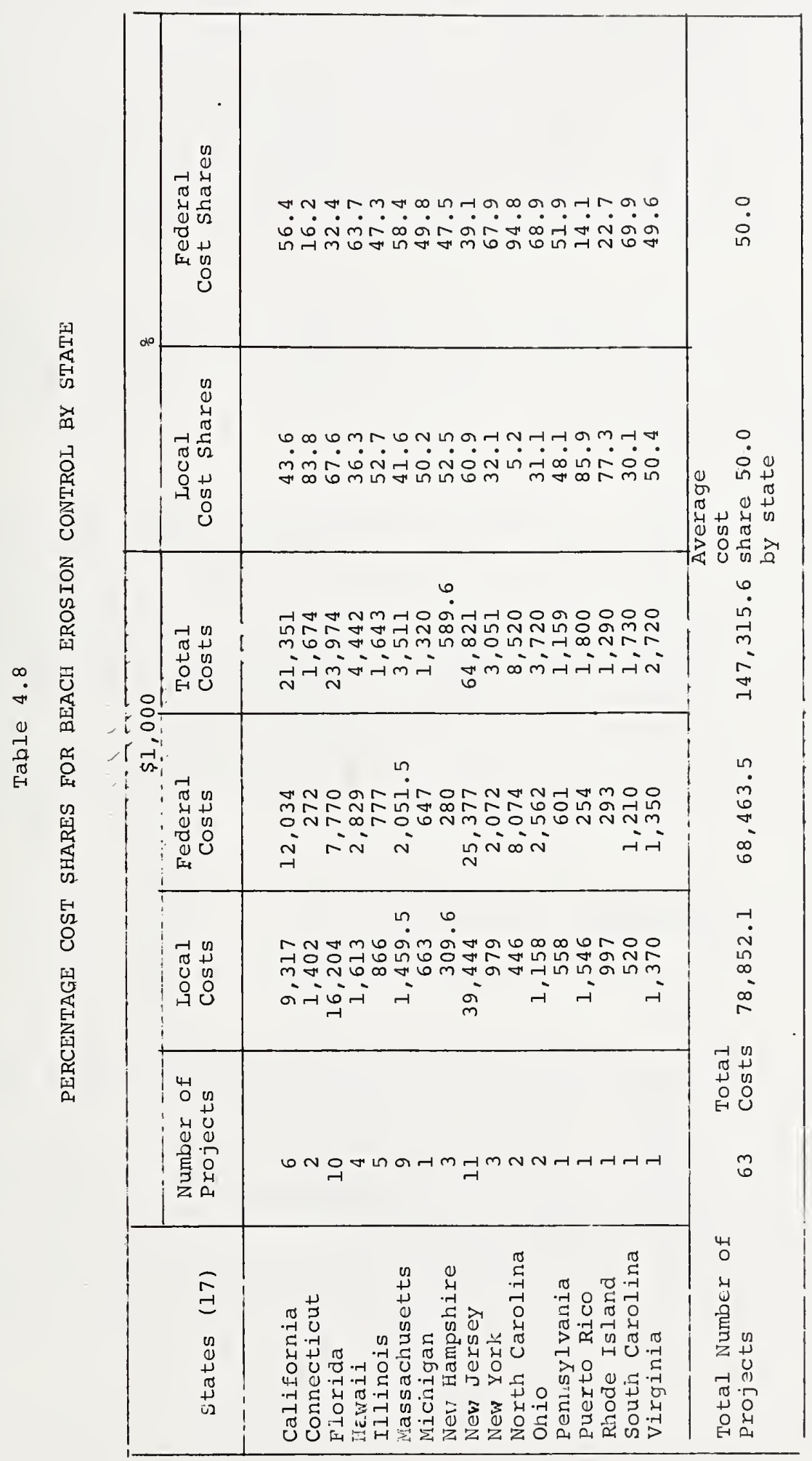


Table 4.8 shows that the local cost share averages by state range more widely for single-purpose projects ( $5 \%$ to $86 \%$ ) than for multiple-purpose ones ( $30 \%$ to $60 \%$ ) as shown in Table 4.7. The average local cost share over the 17 states is $50 \%, 1$ and the average local cost share for the 63 projects is about $54 \% .^{2}$ As we would expect on the basis of the cost-sharing rules, single-purpose beach erosion control projects have higher percentage local shares than projects with hurricane protection.

Another source of data on cost sharing for beach erosion control is a 1967 study by the Corps on Federal reimbursement policies for water projects. The study described total estimated construction costs and the Federal share for 97 projects that were authorized as of June 30, 1966." Table 4.9 summarizes this cost-sharing information. As of the date of the study, 55 of the projects were completed or had extensive plans (starting as early as 1948). The local cost share was 57\% for these projects. No work has been done on 27 of the projects, for which the local cost share is $72 \%$. This lack of local interest could have been due in part to the relatively small Federal contribution.

The remaining 15 projects included some cases of hurricane protection and other unicue situations. The local share was 43\%. The 61\% local share for the 97 projects is, as would be expected, larger than the $42 \%$ local cost share of multiple-purpose projects as shown in Table 4.7, and it is also larger than the 1.6\%, 34\%, and 42\% $10 \mathrm{cal}$ cost shares for multiple-purpose projects described respectively for projects authorized and completed, authorized and underway, and authorized but not yet started, as shown in Tables $4.4,4.5$, and 4.6 .

Emergency restoration under P.I. 84-99 of hurricane or shore protective structures is not a program that is readily substitutable by nonfederal interests for beach erosion control or hurricane protection. The latter programs provide essentially the same kind of protection in the same areas, differing primarily in the degree of protection, and they provide new protection to areas that have generally not been protected before. Emergency protection is for the rehabilitation or restoration of old projects that have already been constructed under one of the other two programs. As discussed in Section 2.3.2, rehabilitation of shoreline protection projects per se is a small proportion of the emergency protection program, even where this program might be substitutable for beach erosion control and hurricane protection. The local choice of emergency protection for a "better deal" does not appear to occur frequently, if at all.

Personnel in the Emergency Operations Branch of the Army Corps of Engineers were interviewed to ascertain what projects had been rehabilitated under P.I. $84-99$ and the cost-sharing arrangements for those projects. ${ }^{5}$ Four projects, described briefly in

\footnotetext{
'See Appendix B for the distribution of beach erosion control local cost sharing by state for the 17 states discussed in Table 4.8 .

4.8. ${ }^{2}$ The calculation for the average local cost share by state is not shown in Table

${ }^{3}$ Examination of Tables 4.7 and 4.8 reveals that for some states (e.g., New York) the local percentage share for a multiple-purpose project mighi exceed that for a singlepurpose project. This might result from a large degree of public ownership and use of the single-purpose beach protection project and/or from low public ownership and use of a large beach erosion component in the multiple-purpose project.
}

${ }^{4}$ U.S. Congress, Senate, Study of Federal Reimbursement Policy for Work by states and other Non-Federal Entities on Authorized Water Resources Projects, Senate Document No. 10, 90th Congress, 1st. sess., February 23, 1967.

${ }^{5}$ Personnel interviewed were: Mr. Michael J. Helpa, Assistant Chief, and Mr. Richard S. Rahte, Chief, Emergency Operations Branch, Operations Division, Civil Works,
U.S. Army Corps of Engineers. 


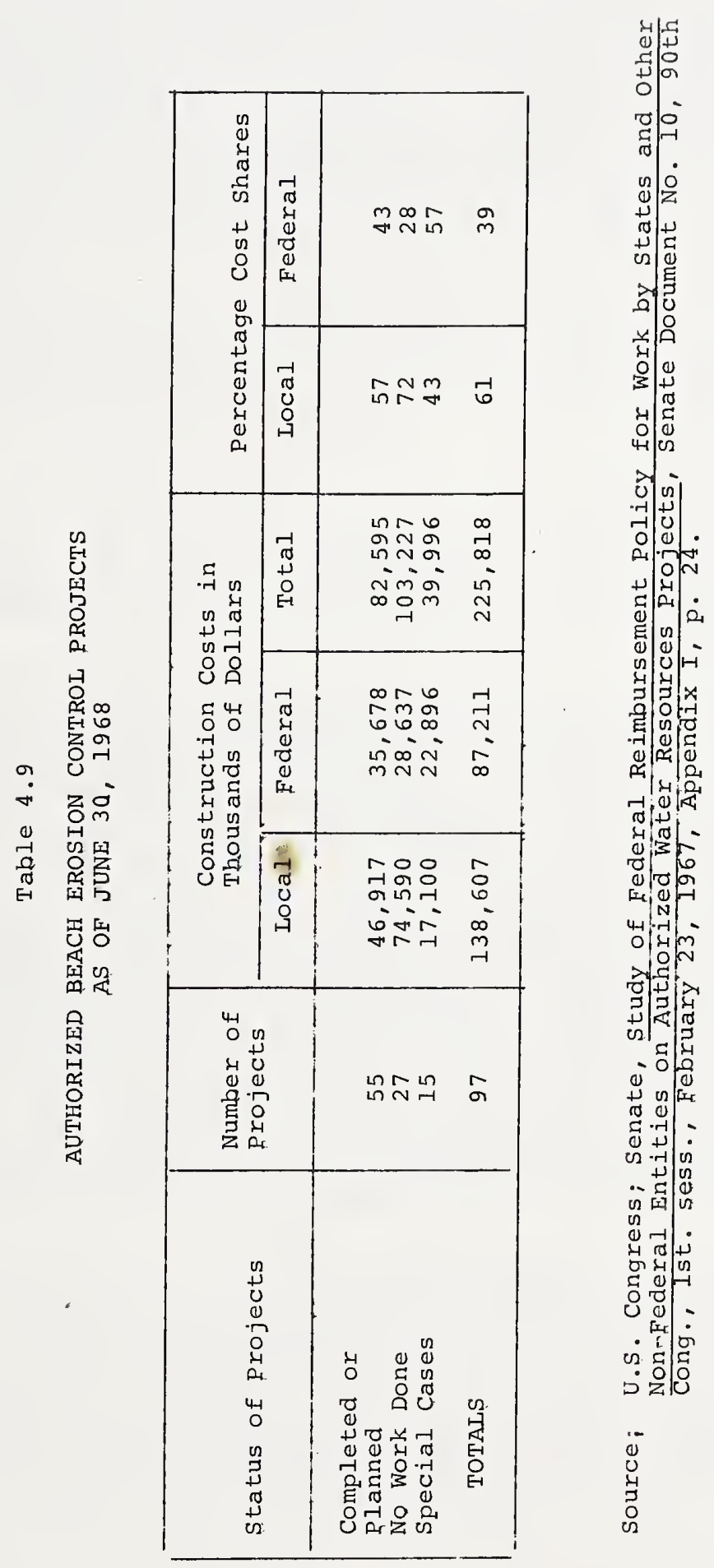


Table 4.10, were suggested as the major restoration projects over the past three years.

The Corps offices of the District Engineer were contacted for each project to determine its status and the actual cost shares that were charged local interests. As would be expected from the rules described in Table 2.1, the Federal government paid $100 \%$ of construction costs for those parts of the restoration projects funded under the P.L. 84-99 program. (Some of the projects incorporated parts funded under the beach erosion control program.) Note that Table 4.10 is for construction costs only. Nonfederal interests still have to contribute lands, easements, rights-ofways, operation and maintenance, and the other requirements that are always local; but to the extent that they were already committed to the original project, there are no substantial additional commitments on the part of the nonfederal interests.

Although differences in cost sharing may not bias local interests in favor of emergency protection relative to the other two programs, there are likely to be scale effects from the Federal government absorbing all construction costs of emergency protection. Inasmuch as nonfederal interests bear no new costs for rebuilding or restoring a project, they may be induced, first, to urge for restoration where in fact the more efficient alternative from the nation's viewpoint might be to leave the project in disrepair (do nothing), and second, to overbuild in relation to the nationally efficient scale.

The efficiency implications of different cost shares among the three programs are first, that nonfederal interests will be attracted to their least-cost program regardless of its cost nationally, and second, to the extent that the local share of the favored program is beneath that dictated by the Association Rule, nonfederal interests will tend to request project sizes that are larger than nationally justifiable.

The choice between hurricane protection and beach erosion best illustrates these efficiency problems. Hurricane protection and beach erosion control programs both protect against storms, but hurricane protection offers a greater degree of protection at a greater national cost. Existing cost sharing discourages local groups from substituting beach erosion control for hurricane protection, however, not just because the former gives less protection, but because it costs more locally for any given level of protection. That nonfederal interests do in fact consider their share of costs when facing a choice between a hurricane protection program and a beach erosion control program is illustrated in Table 4.11. This table was derived from a statement by Robert Cook, Director of the Office of Central Engineering, State of New York Conservation Department, in support of a bill for increasing Federal participation up to $70 \%$ of the costs of projects that include hurricane protection. ${ }^{1}$ Table 4.11 shows that, under present cost-sharing rules, the actual cost to the state or nonfederal entity of protecting a typical section of beach in New York might remain the same or increase very little for three project plans differing significantly as to the level of protection and of national cost. The low Federal.share in beach erosion programs encourages local interests to seek protection under one of the "cheaper" programs that include hurricane protection, although they are more costly to the nation. For example, local interests would be induced to select Plan 2 rather than Plan 1, and if in return for the extra local cost of $\$ 100,000$ for Plan 3 (costing the nation $\$ 500,000)$, the expected benefits exceed $\$ 100,000$, they would select Plan 3 over Plan 2 .

The changes proposed by the state of New York, shown on the right side of Table 4.11, demonstrate that, with a uniform percentage among all programs, local interests could be induced on cost grounds to pick that program which is least costly to the nation. Thus they would prefer Plans 1, 2, and 3, other things being equal, in that order. We should note that the techniques for the 3 plans in this case are essentailly the same, namely dune construction and beach fill. Yet local interests are attracted to their least-cost program, namely hurricane protection. Thus, having lower percentage local cost shares for hurricane protection than for beach erosion control biases local interests to nationally inefficient, oversized projects. ${ }^{2}$

${ }^{1}$ U. S. Congress, Senate, Committee on Public Works, Omnibus Water Resources Authorizations--1970 Hearings, pp. 667-670.

${ }^{2}$ See section 3.3 . 
TABLE 4.10

SHORELINE PROTECTION PROJECTS RESTORED UNDER P.L. 84-99

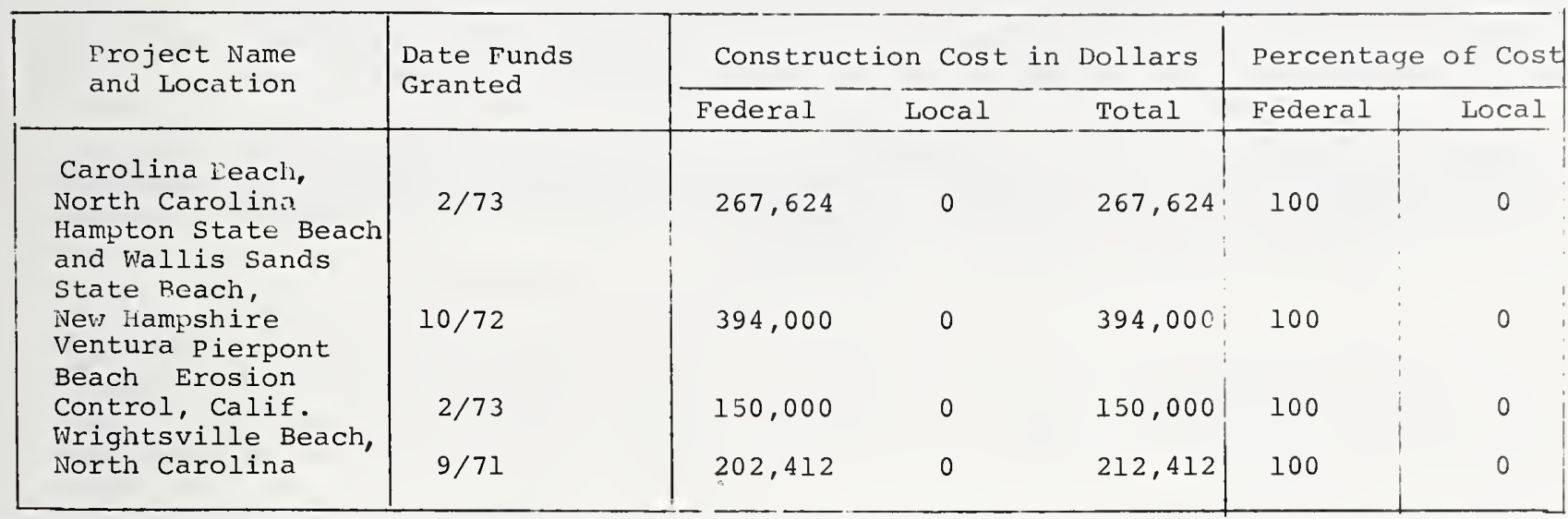

TABLE 4.11

APPORTIONMENT OF COST FOR TYPICAL SECTION OF NEW YORK STATE BEACH

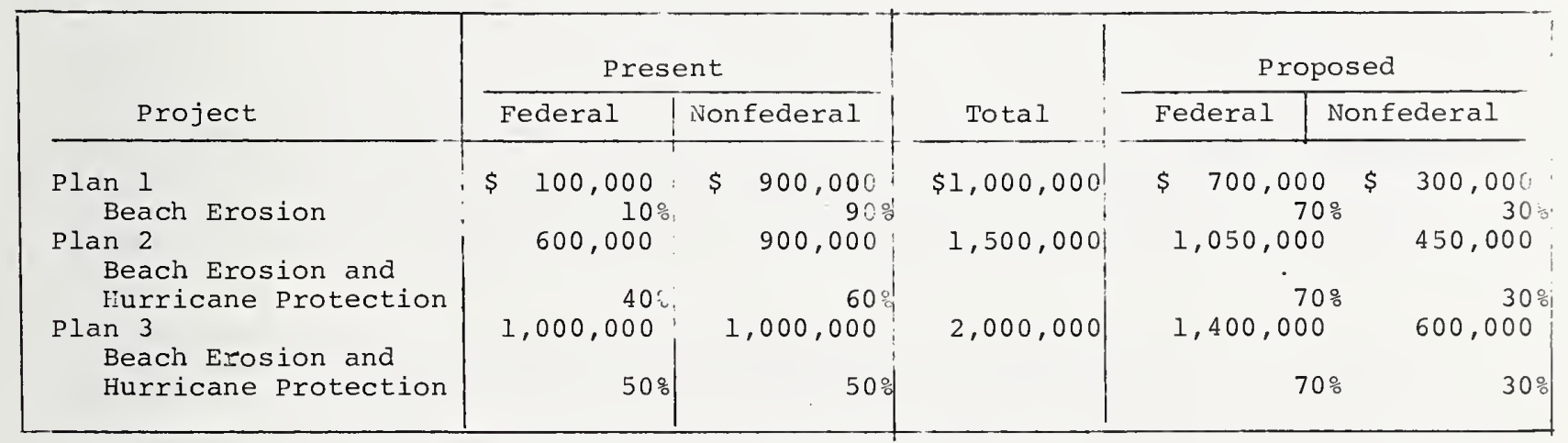


By equalizing the local cost share among program ( $30 \%$ in Table 4.11), we eliminate one bias for oversized projects, but another remains. Under the proposed cost-sharing rules, nonfederal costs are less for every plan than under existing rules. To the extent that local benefits at the margin exceed 308 of corresponding national tenefits, a bias still exists for overbuilding, and it applies to each of the 3 plans. ' Thus, although the proposed cost-sharing rule leads to a more efficient choice among programs, it does not necessarily lead to an efficient choice of project size within that program. An alternative proposal that might eliminate both of these biases will be considered in the final chapter of this report.

No attempt has been made in this report to describe cost-sharing policies of nonfederal interests. Policies vary among states and among programs, and it should be noted that these variations affect local acceptance of shoreline protection projects as do variations in Federal policies. A description of state cost-sharing rules for the North Atlantic region is shown in Appendix C.

${ }^{1}$ Ibid. 
5. EVALUATION OF ALTERNATIVE COST-SHARING RULES WITH RESPECT TO CRITERIA OF FFFICIENCY, EQUITY, AND ADMINISTRATIVE FEASIBILITY

In Cnapter 3 it was shown that the two appropriate cost-sharing rules for inducing local behavior that would be nationally efficient were the Association Rule and the equal cost sharing of all techniques, management as well as engineering, for shoreline protection. In Chapter 4 we examined actual local and Federal cost shares that have been incurred under the three shoreline protection programs. On the basis of the analysis of the legislation in Chapter 2 and the empirical data of Chapter 4 , the efficiency conditions derived in Chapter 3 were shown to have been not satisfied.

This Chapter examines the efficiency, equity, and administrative implications of rules now in existence, rules that are being proposed in legislation, and rules that have been recommended in this paper on the basis of efficiency.

\subsection{Alternatives to Existing Cost Sharing Rules}

There have been many recommendations for changes in the cost sharing of shoreline protection, and most contend that more Federal sharing is needed for helping nonfederal interests afford protection. Section 5.1.1 describes briefly some recent leqislative proposals that chanae the cost sharing for shoreline protection. Section 5.1 .2 summarizes a recommended cost-sharing package based on theoretical considerations in Chapter 3 .

\subsubsection{Rules Proposed in Legislation}

In $1970 \mathrm{Mr}$. Javits introduced Senate Bill 3774 in the 91 st Congress, second session, to raise Federal participation in cost sharing of multiple-purpose beach erosion control and hurricane protection projects to a maximum of $70 \%$. ${ }^{1}$ Current programs were being shared on an average of $56.2 \%$ by the Federal government. ${ }^{2}$ Mr. Javits stated that "Hopefully, the legislation we have proposed will serve to offer some relief to communities in these states hard hit by storms and hurricanes." ${ }^{3}$

In 1972 the 92nd Congress, second session, passed Senate Bill 4018, which included a "Shoreline Erosion Control Demonstration Act." This Act established two new precedents: (1) Federal cost sharing for project first costs of beach erosion control would increase from about 50\% to 75\% and for hurricane protection from 70\% to 75\%, and (2) private property would be eligible for protection under the same cost-sharing terms as public property. The Bill was not signed into law by President Nixon.

Several bills proposed in the 93rd Congress, first session, are essentially the same as Senate 4018 with respect to increased Federal participation in shoreline protection. These are Senate Bill 606 and House Bills 4905 and 4906.

Other bills proposed in the 93rd Congress, first session, affect cost sharing for shoreline protection in several ways. Making private property eligible for Federal participation in beach erosion control projects is one way. This has been proposed in Senate Bill 1161 and House Bills 2437, 2456, 3311, and 4613. Increasing the Federal cost share of beach erosion control projects to $90 \%$ is another way. This is proposed in House Bills 549, 1581, 4487, and 5073. Broadening the authority of the Corps to undertake emergency beach erosion control is a third way. This authority includes repair or restoration of any erosion control structure threatened or destroyed by extraordinary wind, wave, or water action. Senate Bill 1266 , which also provides this authority, is significant in that it implies that all nonfederally constructed projects are eligible for emergency protection and it requires nonfederal interests to contribute only the lands, easements, and rights-of-way for the emergency protection.

${ }^{1}$ U.S. Congress, Senate, Committee on Public Works, Omnibus Water Resources Authorizations - 1970 Hearings, pp. 650-651.

${ }^{2}$ Ibid. p. 658.

${ }^{3}$ Ibid. p. 664 . 
None of these Bills has passed Congress, but the large number of Bills proposed and the mounting support behind them indicates that some change in cost sharing is likely. The implications of the legislation for cost sharing are (1) to increase Federal cost sharing by making heretofore ineligible private property eligible for Federal cost sharing, (2) to raise the percentage of Federal cost sharing for beach erosion control to a range of $70 \%$ to $90 \%$, and (3) to expand emergency protection to nonfederally authorized and constructed beach erosion control projects. These implications will be evaluated in terms of efficiency and equity in section 5.2.

\subsubsection{Recommended Rules}

Two general rules for shoreline protection are recommended here based on the efficiency conditions examined in Chapter 3, the analysis of existing rules in Chapter 4, and the examination of proposed rules in the preceding section. These recommended rules will be compared to existing and proposed rules in section 5.2 .

The first recommended rule is to share the costs of all techniques, engineering and management, equally for a given program (see section 3.3.1). This rule is currently followed to the extent that cost sharing is uniform for traditional techniques of providing a given program, e.g., beach erosion control. But management techniques are not considered because there is no authority to use them. Hence, in effect, unequal cost sharing results; that is, the Federal government pays, for example, up to $70 \%$ for beach erosion control with a groin, but 0\% for protection against erosion damages through condemration and relocation. Thus for the Corps to follow a uniform rule, it would need additional authority to plan for and finance management techniques.

The second recommended rule is for Federal and nonfederal interests to share shoreline protection costs in the same proportion as they share benefits at the margin (see Section 3.3.2). This Association Rule (AR) will therefore vary by project. If for some reason a fixed percentage rule must be established, it should be based on the local incidence of benefits. The degree of public ownership and use are likely to be good proxies for how widespread benefits might be. Thus the local cost share could vary directly with the degree of private ownership and inversely with the rate of public use associated with a project.

The above rules are described here to make it possible, in the next section, to compare these rules to existing and alternative rules. In Chapter 6 these recommendations will be elaborated, and further recommendations will be made regarding insurance and other management alternatives.

\subsection{Evaluation of Existing and Alternative Rules}

\subsubsection{Efficiency and Optimality}

Chapter 3 specified that the term efficient would refer to maximizing net national economic development benefits, whereas the term optimal would refer to maximizing net benefits from a combination of objectives, such as national economic development and environmental enhancement.

The efficiency impact of existing shoreline protection cost-sharing rules was discussed in Chapter 4, and it was found that they may induce local interests to adopt projects that may not be efficient. With respect to the newly recommended objective of environmental quality, there are no current cost sharing rules to evaluate, 1 and thus we do not examine existing rules for optimality. In the remainder of this section, the rules proposed in this paper, which were based on considerations of efficiency, will be evaluated along with an alternative set of rules, as drawn from proposed legislation in Congress.

It was shown in Chapter 3 that the same cost sharing percentage for all technigues of shoreline protection would be necessary if local interests are to be induced to pick the technique, or mix of techniques, that is least costly for the nation. This same rule would apply whether the shoreline protection were planned to satisfy a single or multiple objectives. It was also shown that the Association Rule (AR) was theoretically the only rule that would encourage local interests to adopt the nationally efficient scale.

${ }^{1}$ With the exception of a recommended cost share of $50 \%$ for water quality, no policy for cost sharing environmental quality components has been established. 
The AR will also lead to optimal project designs and suales where the purpose of shoreline protection is to maximize a sum of net benefits from multiobjectives, given a budget constraint. ' That is, if the AR is applied to each component of the multioljective accountis, local interests will be encouraged to select project scales and designs that are nationally optimal. ${ }^{2}$ However, a major problem with multiobjectives is the incommensurable nature of some benefits accruing to accounts otlier than national economic development, such as environmental quality, which precludes tile determination of a national optimum without a politically based weighting scheme.

The implication of the AR for a regional development account would be a $100 \%$ local cost share. Benefits by definition accrue locally or regionally, so local interestswould bear all of the costs. If local shires were below 100\%, local interests would be induced to choose shoreline protection projects over other locally financed development projects which might be more efficient. Furthermore, local interests would be biased to choose oversized shoreline protection projects.

The cost-sharing rules that have been proposea in the 93rd Congress for shoreline protection were summarized in Section 5.1.1 as follows: (1) to increase Federal cost sharing by making heretofore ineligible property eligible for Federal cost sharing, (2) to raise the percentage of Federal cost sharing for beach erosion control to a range of $70 \%$ to $90 \%$, and (3) to expand emergency protection to nonfederally authorized and constructed beach erosion control projects. Each of these policy changes is evaluated with respect to its efficiency implications. ${ }^{3}$

Existing Federal cost sharing for beach erosion control varies directly with the level of public ownership and use (see Table 2.2). This rule is somewhat consistent with the AR in that costs assigned local interests vary directly with the proportion of total benefits that they receive. By changing the rules for beach erosion control so that private property contributing few widespread or public benefits becomes eligible for rederal cost sharing, local interests will be encouraged to demand larger and more numerous beach erosion control projects. Such action is inefficient in that too many resources from the nation's point of view will be allocated to beach erosion control as compared to other types of investments.

Raising the Federal cost sharing percentage of beach erosion control to a range of $70 \%$ to $20 \%$ is a Departure from existing policy (see Tables 2.2 and 4.9 ). and such an increase in the actual percentages paid by the Federal government will induce local interests to demand more and larger beach erosion control projects than under current legislation. Not only does such a rule make additional projects eligible for federal cost sharing, but it increases the contribution of the Federal government as well. The national efficiency impact is likely to be that too many resources will be allocated to beach erosion control.

Proponents of the higher Federal contribution might defend it by explaining that local interests would no longer have a bias for hurricane protection over shoreline protection (as explained in Section 4.2 and Table 4.11) if the Federal contribution were set at the uniform rate of $70 \%$. But as was argued earlier, while one bias towards hurricane protection was eliminated, another was produced. Furthermore, this bias could just as easily be removed by lowering the Federal contribution to hurricane protection to $50 \%$. The aim should ultimately be to bring local costs more in alignment with local benefits.

To broaden the authority of the Corps to repair or restore any erosion control structure (Federal or nonfederal) that is threatened or destroyed by extraordinary wind, wave, or water action also has far reaching implications. First, all nonfederally constructed projects become eligible for emergency relief. Second, not only will the Federal government contribute to the costs of restoration and repair, but it is implied that it will pay $100 \%$ of the costs except for lands, easements, and rights-ofway (most of which have already been borne in an existing project). Third, local

${ }^{1}$ Note that this section does not urge for the adoption of multiobjectives, but simply explains that the AR would lead to optimal development if it were adopted.

${ }^{2}$ An approach to solving this problem has been described by Marshall in "Cost Sharing and Multiobjectives," pp. 2-4.

${ }^{3}$ Since proposed legislation does not describe cost sharing for multiobjective accounts, optimality is not discussed here. 
interests will be induced to rebuild projects that might more efficiently (in the national context) be abandoned and to urge for a more expensive restoration than is nationally efficient.

\subsubsection{Equity}

Equity has two meanings in economics: fairness and redistribution of income. Both concepts of equity will be used here in evaluating existirg and alternative costsharing rules for shoreline protection.

The notion of fairness implies a relevant circumstance with reference to which the judgment about fairness is reached. That is, a cost sharing rule to be fair to all parties must imply that it is fair with respect to some relevant circumstances affecting them ..- not just any circumstance. What is regarded as a relevant circumstance, however, will vary with one's point of view. For example, a Federal agency, acting in the national interest, might be expected to consider the incidence of benefits (local or widespread) to be the relevant circumstance on which to judge tile fairness of a cost-sharing rule, whereas local interests might propose ability to pay as the relevant circumstance. "Benefits received" is assumed to be the relevant circumstance in this report. Thus, for a cost-sharing rule to be fair to all parties, their contributions will have to be in proportion to the project benefits that they receive.

Neither hurricane protection nor emergency protection seems fair in terms of benefits received, since benefits probably accrue to a relatively small number of people in a well defined area, and yet $70 \%$ to $100 \%$ of the costs are borne by the Federal government (see Table 2.1). The existing cost sharing rule for beach erosion control, on the other hand, varies directly with the level of public ownership and use (see Table 2.2), and thereby seems completely fair in terms of benefits received.

The AR that has been recommended in this paper for consideration is based on benefits received at the margin. Thus the rule could be called completely fair only if total benefits happened to be distributed in the same proportion as benefits at the margin.

Rules that have been proposed in legislation to make private property eligible for Federal assistance, to raise the Federal cost sharing percentage for beach erosion control to a range of $70 \%$ to $90 \%$, and to expand emergency protection to nonfederally authorized and constructed beach erosion projects would further divorce the responsibility for costs from benefits received.

Another standard by which fairness. should be judged is continuity. It requires tiat no major change in cost shares should result from a small changé in the relevant circumstance.

Existing rules for hurricane protection and emergency protection are inflexible with respect to the relevant circumstance, since these rules are absolutely fixed in percentage terms. That is, as the incidence of local benefits varies, the percentage local cost share remains the same. The existing rule for beach erosion control is very fair in that as the ratio of public benefits to total beiefits diminishes (see Table 2.2), the local cost share increases. Thus the cost share. varies continuously with the incidence of benefits. The AR will result in a variable local cost share as the incidence of benefits changes at the margin, thereby satisfying the continuity objective. Rules proposed in legislation are in fixed percentage form and therefore the local percentage cost shares do not vary at all with the relevant circumstance.

${ }^{2}$ For a more complete treatment of an evaluation of cost-sharing rules with equity criteria, see Marshall and Broussalian, Federal Cost-Sharing Policies for Water Resources, pp. 201-224. 
Thus we see that the equity in fairness characteristics of relevancy and continuity appear to be more closely satisfied under the existing rule for beach erosion control and the AR recommended hereim than under the other existing rules and those that have been proposed in legislation.

Redistribution of income, the second meaning of equity as it is traditionally used in economics, occurs when shoreline protection benefits and costs accrue to project interests in such a way as to change the prior distribution of income. Conflicts of interests arise in evaluating equity in redistribution because those persons from whom benefits are withdrawn or on whom taxes are raised may not consider such a redistribution to be to their personal advantage or even in the national interest.

No attempt is made in this study to propose an optimal cost-sharing rule for redistributional equity because (1) redistribution is unlikely to be regarded as an objective of shoreline protection, and (2) even if redistribution were considered an objective, there are no generally acceptable weights assigned redistribution relative to other objectives of shoreline protection. ${ }^{1}$

Some observations can be made as to the redistributional impact if tiose rules currently proposed in legislation or those recommended herein were to be adopted. Because shoreline protection is so costly (see Appendix A), we must assume that the benefits accruing from protection would have to be very high to economically justify (i.e., for lenefits to exceed costs) shoreline protection projects. Thus for any economically justified project on private or public land in which the benefits are restricted to a relatively small number of people, we can assume that a large sum of benefits accrues to a small number of people. Furthermore, since beachfront property is commercially quite valuable, we might assume that the net wealth of the owners of beach property is above the national average.

If proposed rules in legislation make private property eligible for Federal cost sharing, and if the Federal contribution is raised, then a perverse redistribution of income is likely to result. That is, instead of redistributing income from higher to lower income persons, which is usually the preferred direction of redistribution, ${ }^{2}$ the general taxpayer will be paying taxes to generate benefits for a small segment of the population who probably represent a group with higher than average incomes. ${ }^{3}$

If the AR were implemented, it is unlikely that there would be any redistribution. That is, beneficiaries would pay and there would be no transferring of net income or wealth between general taxpayers and beachfront property owners.

\subsubsection{Administrative Feasibility}

Cost sharing rules for shoreline protection are administratively feasible when they are simple to understand and reruire reasonable effort and expense in collecting the necessary information to determine local cost shares.

Existing rules are difficult for local interests to understand in that they perceive different real cost shares for different cost sharing programs (e.g., beach erosion versus hurricane protection), and therefore local interests may hesitate in selecting a given program for fear of not getting the "best deal." Rules proposed in legislation might be less complicated for local interests in that cost sharing will be less varied among programs. The AR, albeit based on a simple-to-understand principle, would probahly be most difficult to unäerstand.

Existing rules do not recuire any unreasonable effort and expense in collecting information for determining shoreline protection cost shares. The process for computing local shares for beach erosion control (see section 2.3.3), however, is more

${ }^{1}$ For a discussion of the relationship between cost sharing and redistribution, and of the implications of using cost sharing as a tool to effect various kinds of redistrilution, see Marshall and Broussalian, Federal Cost-Sharing Policies for Water Resources, pp. $216-224$.

"The progressive tax structure in the U.S., which taxes high income persons progressively more than low income persons (other things being ecual), is supposed to bring about a desirable redistribution of income.

${ }^{3}$ For a discussion of perverse redistrilution in water projects, see Marshall and Broussalian, Federal Cost-Sharing Policies for Water Resources, pp. $220-224$. 
complicated than the process for the hurricane protection and emergency protection programs. The $A R$ would require more information than the other rules, reçuiring additional effort and expense, although probably not in an amount to be considered excessive. To identify keneficiaries of shoreline protection would not be too difficult since local owners of the shoreline, and in most cases the users, can be determined. The local rules proposed in legislation again would require no unreasonable effort or expense, except in the sense that (1) making private property eligible and (2) raising Federal contributions will probably increase the demand for shoreline protection so that much more cost sharing and other planning effort will be required of the Corps.

\subsection{Summary}

Cost-sharing rules for shoreline protection that are currently being proposed in bills before Congress have been described. Cost-sharing implications are increased eligibility for Federal contributions for private property, increased Federal cost shares for shoreline protection, and increased eligibility for Federal contributions on emergency work for nonfederally authorized and constructed projects.

Existing rules, those proposed in legislation, and the AR developed in this paper have been evaluated with respect to the criteria of national economic efficiency (optimality), eouity, and administrative feasibility.

Table 5.1 summarizes the evaluation of the three sets of rules with respect to the three criteria. Existing rules for buach erosion control are ranked GOOD in terms of the first two criteria and FAIR in terms of the third, whereas hurricane protection and emergency wrotection are ranked POOR for the first two criteria and GOOD for the third. The AR ranks GOOD on efficiency grounds, but only FAIR with respect to equity and administrative feasibility. Proposed rules in legislation are ranked POOR on both efficiency and equity grounds, and FAIR to GOOD in terms of administrative feasibility.

Recommendations for specific cost sharing rules should be made with the considuration of all relevant criteria. In the Summary and Recommendations chapter that follows, we suggest specific rules for shoreline protection.

TABLE 5.1

EVALUA'IION OF COST SHARING RULES

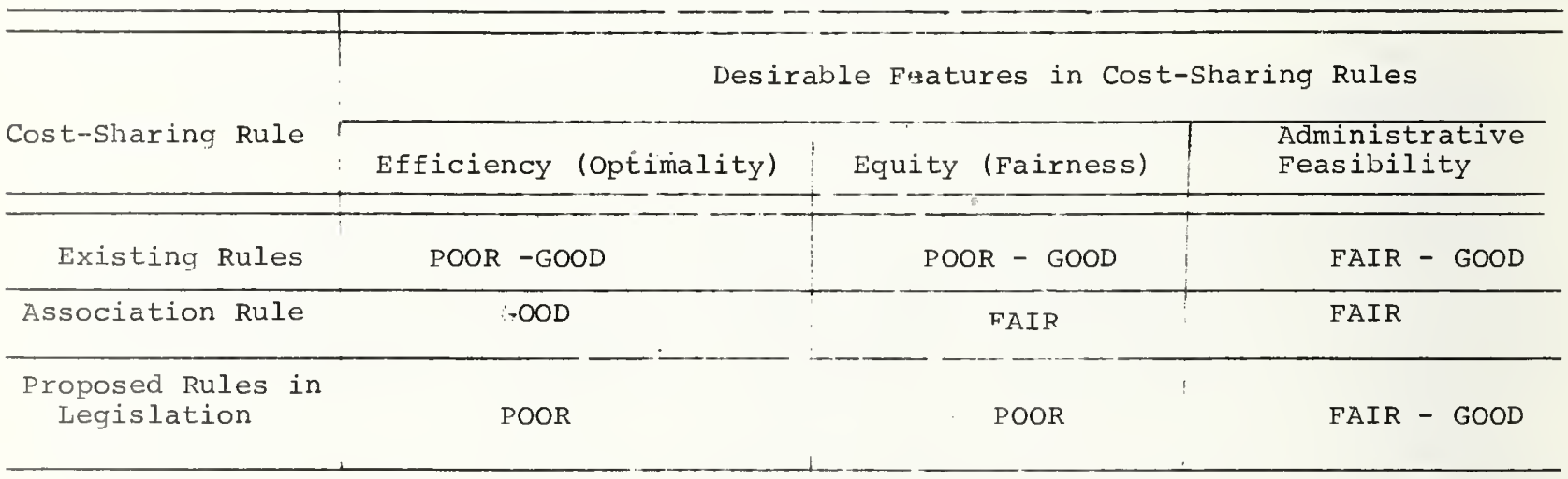




\subsection{Summary}

Current cost-sharing rules for shoreline protection have been criticized both by nonfederal and Federal participants in programs designed for beach erosion control, huriticane protection, and emergency protection. Critics have soid that existing rules are inefficient, inequitable, inconsistent among programs, and difficult to understand and administer.

In this stuảy three sets of cost-sharing rules have been evaluated with respect to criteria of national efficiency, equity, and administrative feasibility. The three sets of rules include existing rules, those proposed in current legislation, and two rules (the Association Rule (AR) and the same percentage cost share for all technicues) which are recommended in this report.

The national efficiency problem of existing cost-sharing rules for shoreline protection is that they encourage local interests to seek techniques of protection (e.g., groins) and scales of development (usually oversized scales) which may be economical from the local point of view, whereas from the national point of view, other techniques (e.g., zoning) and smaller scales might be more efficient. Existing rules also vary between programs (e.g., beach erosion control versus hurricane protection) that are esseatially the same except that one delivers a greater degree of protection than the other. A description of existing cost sharing rules, a theoretical explanation of cost--sharing inducements, and statistics on actual cost shares seem to confirm that existing rules will bias nonfederal interests against nationally efficient projects.

Rules proposed in legislation for shoreline protection entail one or more of the following three provisions: (1) an increase in Federal cost sharing by making heretofore ineligible private property eligible for Federal cost sharing, (2) an increase in the percentage of Federal cost sharing for beach erosion control to a range of $70 \%$ to $90 \%$, and (3) an expansion in emergency protection to nonfederally authorized and constructed beach erosion control projects. Adoption of these rules would encourage local interests, first, to seek larger, and possibly oversized shoreline protection projects; second, to seek more projects than under existing rules; and third, to seek protection through repair of existing structures that might more efficiently be abandoned. It is quite conceivable that raising the Federal contribution per project will result in fewer Federally assisted projects than under current rules.

The AR reouires that local interests be charged a percentage of all project costs that is equal to the proportion that local benefits bear to national benefits at the margin. By associating local costs with benefits received, $10 c a 1$ interests will not be induced to select projects that are nationally inefficient. Since the AR makes no distinction among different techniques or categories of cost, it is completely consistent with the other rule recommended here, namely that each technique be shared in the same proportion. Thus if zoning, insurance, and groins were all substitutes for providing some given level of protection, by cost sharing each in the same proportion, nonfederal interests would tend to pick the least-cost technigue (s).

Each of the three sets of rules were also evaluated with respect to the criterion of equity, where equity is used in the sense of fairness. Existing rules were ranked from POOR to GOOD in terms of fairness, proposed rules were ranked POOR, and the AR was ranked FAIR. Rules that have been proposed in legislation and the AR were also evaluated with respect to equity, where equity refers to redistribution of income or wealth. Redistribution would seem to be perverse for proposed rules; that is, increased Federal cost sharing woulä probably redistribute income and wealth in favor of people of relatively high income or wealth positions. For the AR, there would seem to be little redistribution of income and wealth.

For the criterion of administrative feasibility, both existing and proposed rules in legislation ranked FAIR to GOOD, whereas the Association Rule ranked FAIR. This ranking for the $\mathrm{AR}$ is attributed to the extra information needed for its implementation. 
The implications of the recommendations made in this report (listed in the following section) are that (1) local cost shares for shoreline protection will increase, (2) the local demand for enginesing techniques of protection will decrease relative to the demand for management techniques, and (3) Federal expenditures for management techniques will increase relative to expenditures for structural technigues. Implementation of the AR would probably require local interests to pay more and the Federal qovernment to pay less of the project costs, on the average, than they have under existing rules (with the possible exception of beach erosion crintrol for property with little or no public use). However, through the selection of efficient technigues and scale of shoreline protection, the corps would be able to assist in the planning for and the rrotection of more shoreline areas than under the current set of rules. A final benefit from implementation of the recommendations is that local groups and taxpayers in general would be treated more fairly in that the costs of shoreline protection would be more closely associated with the beneficiaries.

\subsection{Recommendations}

Cost sharing has been shown to be an inducement for influencing local interests in their decisions on the scale and combination of techniques to be used in developments for shoreline protection. Alternative cost-sharing rules have been evaluated on the basis of their incertive effects on local interests in choosing projects designed to maximize a single objective, national economic efficiency, as well as to maximize multiple objectives, including environmental quality. The following recommendations are made in the perspective of using cost sharing as an incentive mechanism to reach these objectives of the shoreline protection program.

\section{(1) The Association Rule}

The AR, on grounds of efficiency and equity, is recommended as a general costsharing rule for beach erosion control, hurricane protecticn, and emergency protection. It should be applied to all project costs, including beach nourishment and general operation and maintenance. Only the AR will induce local interests to select shoreline protection projects that are built to the scale that is nationally efficient (or optimal in the case of multiobjectives).

If the issociation Rule is not applied for political or administrative reasons, a second-best solution would be to retain the existing percentage rules for beach erosion control, but to reduce Federal cost-sharing of the other two programs, hurricane protection and emergency protection under P.L. 84-99, to 50\% to make them more consistent with beach erosion control. Again, all categories of cost should be shared according to the percentage rules.

\section{(2) Same Percentage Cost Share for All Techniques, Engineering and Management}

The same percentage cost share should apply to all technicues for providing shoreline protection, be they engineering (groins, seawalls, breakwaters) or management (insurance, zoning, codes). This means that the corps would need new authority to plan for and cost share in techniques that currently lie outsire of its domain.

Planning for and co:i sharing in all techniques of shoreline protection will result in the local adoption of more efficient techniques and more actual protection for any given budget. Furthermore, introduction of management techniques would provide more flexibility in altering the degree of protection. Codes and zoning restrictions can be changed more quickly, easily, and inexpensively than a breakwater that has been built for shoreline protection. Engineering structures, once built, tend to be relatively permanent investments, whereas, management applications might be rescinded or extended at will. Also, given the great expanse of underieveloped shoreline subject to erosion, management techniques that preclude damage-prone development appear particularly cttractive. Finally, management techniques appear to be more consistent with the environmental quality objective than conventional engineering teciniques.

Insurance, as a form of management technique, is endorsed here as a viable alternative for protection against damages. Hurricane and high tide insurance might be offered at true actuarial rates for new development along the shoreline, and at subsidized rates for existing developemnts. The fact that flood insurance has not been widely accepted by local interests, even at subsidized rates, does not mean that such a program is destined to failure, but merely that sufficient incentives for local adoption have not been provided. Mandatory insurance coverage required by mortgage institutions, both for builders and consumers of shoreline buildings, would encourage its adoption by lowal interests. 
The potential role of management technioues nas been recognized, as is incicated in the following statement taken from tile Corps' brief to Conaress on the National Siloruline Study:

Shore management tecinicpes to minimize damages appear more apuropiate than protection to halt erosion for approximately 85\% of the slloreline undercoinc significant erosion. . . .

$A$ conlination of protection and management-type measures may prove most cconomical and practical in many locations when detailed studies are macie. Shore management is a very uroad continuing l'rocuss of researchinr, planning, predicting changes, and imulomentinn by regulation, development or other means, leading to lreservinc! and eniancina the shore in the best interest of all concerneci.

(3) Same Porcentage Cost Share for All Cost Categories

All categories of project costs (i.e, construction, lands, easements, and rightsof-ray, operation and maintenance, and relocation and alteration of utilities) should have the same percentage cost share applied to them. (This recommendation is implied in tine $A R)$.

Adoption of this policy would eliminate any bias that might encourage local interests to choose a more expensive project over a less expensive one (from the stancipoint of tine nation) simply because the actual costs incurred locally would be less for the expensive project due to different cost-sharing rules among cost catecories, e.g., between construction and operation and maintenance costs.

\section{(4) Cost Sharing as an Incentive}

It is recommended that cost sharing be used as an incentive by Federal agencies to encourage local interests to comply with certain minimum recuirements for shoreline protection. For example, a local community might be considered ineligible for cost sharing under any shoreline protection program if it were to allow building seaward of the foredune. Or a Federal agency might reasonably be expected to refuse cost sharing with any community that failed to adopt some land use plan for the shoreline area. Adoption of management alternatives would in many cases reduce the demand for engineering struatures and therby make available more money for alternative forms of protection.

\subsection{Suggestions for Further Research}

Research and evaluation carried out in preparation of this report uncovered many additional areas of research that might be of value to the Corps in considering alternative cost-sharing rules for shoreline protection.

One type of information needed is data on the incidence of benefits from shoreline protection projects. If the proposition is accepted that efficiency and equity depend on associating costs with lenefits, then any cost-sharing rule based on this proposition requires a knowledge of to whom benefits accrue and in what amounts.

A second type of useful information is a description of the legal and other institutional constraints that would prohibit the Corps and nonfederal interests from entering into agreements to provide shoreline protection through management techniques. The first step in implementing management techniques is to identify those institutional barriers that must be overcome.

A thira research area is an examination of the costs of management technigues for shoreline protection. Ex post and ex ante cost studies of shoreline protectior. already provided and considered for the future might be made for conventional technigues versus management techriques such as purchase (conclemation) and relocation, restrictive zoning and codes, or general land use regulations.

A fourth research topic is the evaluation of forthcoming legislation on cost sharins in terms of the efficiency and equity criteria presented herein, and to compare the expected nonfederal and Federal costs of shoreline protection under rules now in existence, proposed in legislation and recommended in this report.

${ }^{1}$ U.S. Congress, House, Committee on Public Works, Projects Proposed for Ombibus Piver and Harbor Legislation - - 1972, Joint Hearings, p. 62 . 
A fifth research area that might be appropriate for the Corps is to classify coastal areas by degree of susceptibility to shoreline damages. This information could be made available to all pruchasers of shoreline property so that they would have some indication of the risk that they incur in buying and building on that property.

In closing this paper, it is emphasized once again that management techniques should be made eligible for planning and cost sharing by the Corps. We in this country have been able to afford expensive techniques for protection, whereas less developed countries have not. The United States could possibly learn from other countries' experiences that engineering techniques are not always the best. This is appropriately demonstrated in the following quote from a Malaysian newspaper account of the sovernment's latest approach to flood protection:

"Swimming Lessons to Prepare for Floods"

Two Ministries have been holding swimming lessons for East Coast residents in preparation for the monsoon season.1

Should the Corps be given the authority to consider such simple but inexpensive alternatives as swimming lessons in addition to the conventional alternatives of building dams and levees? 1972 .

"The Malay Mail, "Swimning Lessons to Prepare for Floods," November 10 , 


\section{A.1 Engineering Technicues}

Beach erosion occurs when the quantity of sediment that is being carried from the beach exceeds the quantity of sediment accumulating on the veach. A beach is considered stable if, over a lona period of time, the processes of accumulation and erosion are balanced, even though the weach constantly undergoes change. ${ }^{1}$

Beach staulity is a function of three basic factors: the anount, type, and size of sediment and materials making up the beach; the strength of erosional forces such as vaves, currents, and winds; and the variability of the sea level. ${ }^{2}$ Thus a beach with fine, loose sand would be more vulnerable to erosion than would be a cliff of hard materials, such as a rocky headland. Shorelines subjected to hurricane winds and waves vould be more vulnerable to erosion than shorelines not experiencine these severe natural forces. And a rising sea level relative to the land mass would we expected to result in a retreating shoreline.

While veacises exposed to the above described conoitions are retreating, it should be noted that there are beaches that are actually growing by accumulating deposits. Little attention is giver here to the natural process of beach building because this is regarded as a windfall benefit by those who see their property grow. Consequently they do not regard it as a problem.

Engineering works generally control the interaction process of the water and wind against the shore. Nature provides its own engineering works that have proved somewhat effective as long as man has not interfered with her natural processes. ${ }^{3}$ Broad, gently rising beaches weaken the force of waves as they climb the foreshore. Offshore bars are formed which cause waves to break and dissapate their energy before reaching the foreshore of the beach. A crest of sand is built up on the beach by normal wave action that holds back all but high storm waves. Beyond this crest lies the broad, flat beach area called the berm, which provides a further dampening effect on any waves that reach it.

A natural levee against the sea is formed behind the beach in the form of a dune. Winds create the dunes, and when shrubs and grasses grow on them, they become somewhat stabilized against further shifting from the wind.

Fiurricanes and storms, particularly the "Northeasters" on the Atlantic coast, sometimes break through these protective dunes, resulting in an "overwash" of salt water and sand inland of the dune. The overwash phenomenom is common along the barrier beaches that form a buffer zone along most of the Atlantic coast from New York to Mexico. Barrier beaches are separated from the inland shore by shallow lagoons or salt marshes which provide additional protection to the mainland from severe storms.

Dolan and Godfrey have explained the defensive role of the natural barrier islands along the North Carolina coast as follows:

The unaltered barrier system can meet the challenge of periodic extreme storms since there is no permanent obstruction in the path of the waves and surge. Most of the initial stress of an extreme event is sustained by the broad beaches. Because no resistance is created by impenetrable landforms, water flows harmlessly between the dunes and across the islands with the result that wave energy is rapidly exhausted. The combination of high tides and waves occasionally succeeds in eroding the beach-face and low lying foredunes and carrying sand and shells inland or completely across the island and into the marsh.

\footnotetext{
${ }^{1}$ Robert Dolan, U. S. Department of the Interior, National Park Service, Beach Erosion and Beach Nourishment, Dune Stabilization Study, Natural Resource Report No. 4 (Washington: National Park Service, 1972), p. 2 .

${ }^{2}$ Ibid.

${ }^{3}$ This discussion comes in part from U.S. Department of the Army, Corps of Engineers, Shore Protection Guidelines, pp. 7-9.
} 
Because of steadily rising sea level ( 3 inches since 1963)

the beaches have, in most places, receded resulting in increased wave energy on the dunes and subsequent overwash and build-up in the interior sandflats and the marshes. The net effect of this process has been a gradual westward movement of the islands.'

Given that the general objective of the shoreline protection program is to reduce damages from shoreline erosion, one alternative to be considered is doing notling to protect the shoreline. The National Park service has adopted this policy in some areas of its National Seashores. Robert M. Linn, the director of the Park Service's office of Natural Science Studies has said that "...allowing nature to take its course is already policy on uninhabited islands." 2 Doing nothing is not politically and economically feasible for those shores that have been developed, however, and the engineering techniques that are described in the rest of this section have been utilized in an attempt to reduce erosion damages for such areas. ${ }^{3}$

Dunes can be built by man for protection against high tides and storm surges. A fast but expensive approach is to use a bulldozer. A slower yet less expensive approach is to use brush, fences (snow fences being most common), and vegetative cover (e.g., American Beachgrass) to trap and hold wind-borne sand in a dune line. ${ }^{4}$ These trapping methods are particularly attractive to individual landowners who want to do something at a reasonable cost and who do not qualify for Federal assistance in providing expensive structural barriers. Furthermore, the sand catching methods build a dune that protects landowners' property both from the action of the sea and from drifting sand. In some areas dunes as high as four feet have been built in less than a year with snow fences. 5

Beach nourishment and restoration, i.e., the pumping or placing of sand on the beach to extend its area, is a technique that can be used periodically to maintain an eroding shoreline. Sand for the eroding shoreline can be borrowed from offshore, inland, or coastal inlet sources. The feasibility of beach nourishment depends on such factors as the sand characteristics, the technology of dredging and pumping, the moving and transportation costs of sand, and the environmental impact of borrowing sand. ${ }^{6}$ The initial beach fill may cost from $\$ 50$ to $\$ 300$ per foot. Subsequent periodic nourishment at one to five-year intervals may be $\$ 15$ per foot per year. ${ }^{7}$

Vegetative cover, by holding sand in place, provides protection against erosion both on and off of dunes. This is most successful along the backshore areas that are not exposed to severe wave erosion forces. ${ }^{8}$

${ }^{2}$ Robert Dolan and Paul Godfrey, U.S. Department of the Interior, National Park Service, Dune Stabilization and Beach Erosion, Dune stabilization Study, Natural Resource Report No. 5 (Washington: National Park Service, 1972), p. 2 . 397 .

${ }^{2}$ Dietrick E. Thomsen, "As the Seashore Shift's," Science News, CI (June 17, 1972),

${ }^{3}$ For explanations and pictures of the engineering techniques that are explained in this section, see U.S. Department of the Army, Corps of Engineers, Shore Protection Guidelines, pp. 25-54.

${ }^{+}$For a detailed description of how to build and save dunes, See John A Jagschitz and Robert Wakefield, How to Build and Save Beaches and Dunes, Marine Leaflet Series No. 4, Agricultural Experiment Station Bulletin 408 (Kingston: University of Rhode Island, 1971).

${ }^{5}$ Ibid. , p. 2 .

${ }^{6}$ Dolan, Beach Erosion and Beach Nourishment, p. 18. p. 53.

${ }^{7}$ U.S. Department of the Army, Corps of Engineers, Shore Protection Guidelines,

${ }^{8}$ For a detailed discussion of the establishment, fertilization, and seeding of vegetative cover, see John A. Jagschitz and R. S. Bell, American Beachgrass, Agricultural Experiment Station Bulletin 383 (Kingston: University of Rhode Island, $1966)$. 
Groins are structures made of rock, concrete, timber, or steel that extend from the backshore out into the water where they act as a barrier to trap sand that is being carried parallel to the shore as "littoral drift." The longshore current that carries the littoral drift is interrupted by the groins which accumulate sand along their updrift side. One problem witl groins is that they sometimes starve the downdrift beaches (an external diseconomy) from the normal littoral transport supply of sand. This may require periodic nourishment of the groins in the form of pumping or hauling sand to the beach. The cost of groins, excluding any beach nourishment that might be required, ranges from $\$ 100$ to $\$ 350$ per foot of shore protected.

Bulkheads, seawalls, and revetments are used to protect seaside facilities located beside the water and the seaward faces of bluffs and dunes. A bulkhead is a wave-resistent vertical wall that protects shore-front property from the sea. A seawall is typically a stronger structure that can protect shore developments from very strong waves. Revetments are rock or concrete-block armor plating that is used to face the sides of bluffs and dunes to arrest erosion. Bulkheads and revetments usually cost from $\$ 75$ to $\$ 150$ per foot, and for some areas may exceed $\$ 400$ per foot. Seawalls are more expensive, ranging from $\$ 200$ to $\$ 500$ per foot. ${ }^{2}$

Breakwaters are offshore structures that prevent waves and swells from eroding tine shores or from disturbing a protected harbor area. Even when the breakwater is built specifically for protecting a given beach, it starves downdrift beaches by blocking tire normal littoral transport of sand. Breakwaters cost from $\$ 200$ to over $\$ 500$ per foot. ${ }^{3}$

Jetties extend seaward from the mouth of inlets to dam the sand stream, thereby keeping sand from choking the inlet and obstructing navigation. Jetties are generally constructed of steel, rock, or concrete. Downdrift erosion results from damming of the littoral transport by the jetty unless sand is trucked or pumped to the downdrift side of the jetty.

The brief descriptions above cover most of the engineering techniques that the Corps has exercised in its "man against the sea" role of protecting beaches. Several points need to be emphasized here regarding the engineering techniques. First, because many of the structural measures are so expensive, they are not economically feasible for individual property owners. Their high costs do encourage, however, careful consideration on the part of local and Federal interests as to the most efficient (least costly) engineering technique for protection. Furthermore, since the existing cost-sharing rules apply the same percentage for every engineering technigue (see section 2.3) of providing shoreline protection, there does not appear to be any cost-sharing bias against the least-cost engineering technique as in favor of more expensive techniques.

Second, engineering techniques can be relied upon to provide effective protection in many cases only when an extended segment of the shoreline is included in the project. The Corps has found the following:

Separate protection for shore reaches or eroding shores (as an individual lot frontage) within a larger zone of eroding shore, is difficult and costly. Such protection often fails at the flanks as the adjacent unprotected shores continue to recede. Partial or inadequate protective measures may even accelerate erosion of adjacent shores. Coordinated action under a comprehensive plan which considers the erosion process over the full length of the receding shore segment is much more effective and economical. p. 43.

${ }^{i}$ U.S. Department of the Army, Corps of Engineers, Shore Protection Guidelines,

${ }^{2}$ Ibid. , p. 33

${ }^{3}$ Ibid.

${ }^{4}$ Ibid. , p. 30. 
Finally, because engineering techniques are most effectively applied for a long stretch of beach, the Corps will generally be dealing with a group of beach owners or beacl interests. Nonfederal interests must be represented by a group that commits itself to the local cost share to become fully eligible for Federal cost sharing. The more people that are involved in such a local entity, the more difficult it may become for them to agree upon their cost-sharing commitment. Additional complications arise due to the differences in local requirements along a beach characterized by varying degrees of public ownership and use.

\section{A.2 Management Techniques}

Management techniques influence, restrict, or control man in his use of the shoreline. The Corps does not have the legal authority to use all of the techniques to be described in this section. Many are under the exclusive jurisdiction of state and local governments. Yet to achieve an optimal solution to the problems of shoreline management, management techniques should be considered. ${ }^{1}$

Requlatory Controls are techniques commonly under the authority of local governments. Zoning, for example, is enacted by local governments to regulate individual land use so that adjacent property owners and the community at large will not be adversely affected (i.e., suffer external diseconomies). An example of a zoning requirement that might help prevent damages from beach erosion would be to impose minimum setback distances from the mean high water mark.

Suldivision regulation is another regulatory technique that local governments can use. A subdivision developer can be required to provide protection in shore areas that he develops. Building codes control the construction of buildings. Codes migit include specifications such as the quality and strength of materials or the height of the floor above mean high tide. Each specification is intended to decrease the damages from hign tides and winds. Ordinances can be passed by local governments to cover problems not handled by other regulatory legislation. An example of an ordinance designed to protect the backshore is the prolibition of any destruction of the foredune along the coastline. Permits require a developer or builder to obtain the permission of an authorizea government agency before building on or modifying the shoreline. The Corps has two permit authorities which might give some precedent for control of shoreline use. One is the rignt to approve any construction or action which affects navigable waters, and the second is to monitor discharges into navigable waters. ${ }^{2}$

The acquisition of property in an area subject to erosion is another technique for reducing erosion damages. To preclude shoreline development and damages that are likely to result from it, a government agency might acquire easements or fee simple title to shoreline property through voluntary donation, direct purchase, or condemnation.

Various government inducements might also be used to encourage private interests to utilize the shoreline in such a way that erosion damages are minimized. High property taxes could be imposed for developments along the shoreline that invite damages, whereas lower taxes could be imposed for land uses that are not subject to erosion damages.

${ }^{1}$ For a detailed discussion of management techniques, see U.S. Department of the Army, Corps of Engineers, Shore Management Guidelines, A Part of the National Shoreline Study (Washington, D.C.: U.S. Army Corps of Engineers, 1971). p. 42 .

${ }^{2}$ U.S. Department of the Army, Corps of Engineers, Shore Management Guidelines, 
Federal insurance for shoreline damages could be made available at premium rates tilat reflect actual risks so that people along the shoreline would recognize tile real economic costs of building on the beach. The National Flood Insurance Act of 1968 provides for a subsidized premium rate for shoreline development until the Secretary of Housing and Urban Development has identified anc puilished information awout the flood hazard possibilities of a given area, after which any construction to '.e started will be insured only at the true risk premium rate. ${ }^{1}$

Federal insurance and Federal grants in general, including cost-sharing for shoreline protection, would be restricted to areas in which local or state authorities have adopted appropriate land use and control measures consistent with reduction in shoreline damages. Here again the National Flood Insurance Act has set a precedent in that, after a specified date, no flood insurance will be made available in any area which fails to adopt adequate land use policy that discourages development and construction in flood-prone areas. ${ }^{2}$

${ }^{1}$ National Flood Insurance Act of 1968, P.L. 90-448, 90th Cong., August 1, 1968, Sec. $1 \overline{308(c)}$.

${ }^{2}$ Ibid., Sec. 1316 and Sec. 1361. 


$\begin{array}{llll}\text { Percentage of } & \text { Number } & \text { Percentage } & \text { Cumulative Percentage } \\ \text { Cost Shared by } & \text { of } & \text { of } & \text { of States less } \\ \text { Local Interests } & \text { States } & \text { States } & \text { than Lower Limit }\end{array}$

$\begin{array}{rrcr}0-9.9 & 1 & 5.9 & 0 \\ 10-19.9 & 0 & 0 & 5.9 \\ 20-29.9 & 0 & 0 & 5.9 \\ 30-39.9 & 4 & 23.5 & 5.9 \\ 40-49.9 & 3 & 17.6 & 29.4 \\ 50-59.9 & 4 & 23.5 & 47.0 \\ 60-69.9 & 2 & 11.8 & 70.5 \\ 70-79.9 & 1 & 5.9 & 82.3 \\ 80-89.9 & 2 & 11.8 & 88.2 \\ 90-100 & 0 & 0 & 100.0\end{array}$

Total $17 \quad 100.0$

APPENDIX C

STATE COST SHARING IN SHORELINE PROJECTS ${ }^{a}$

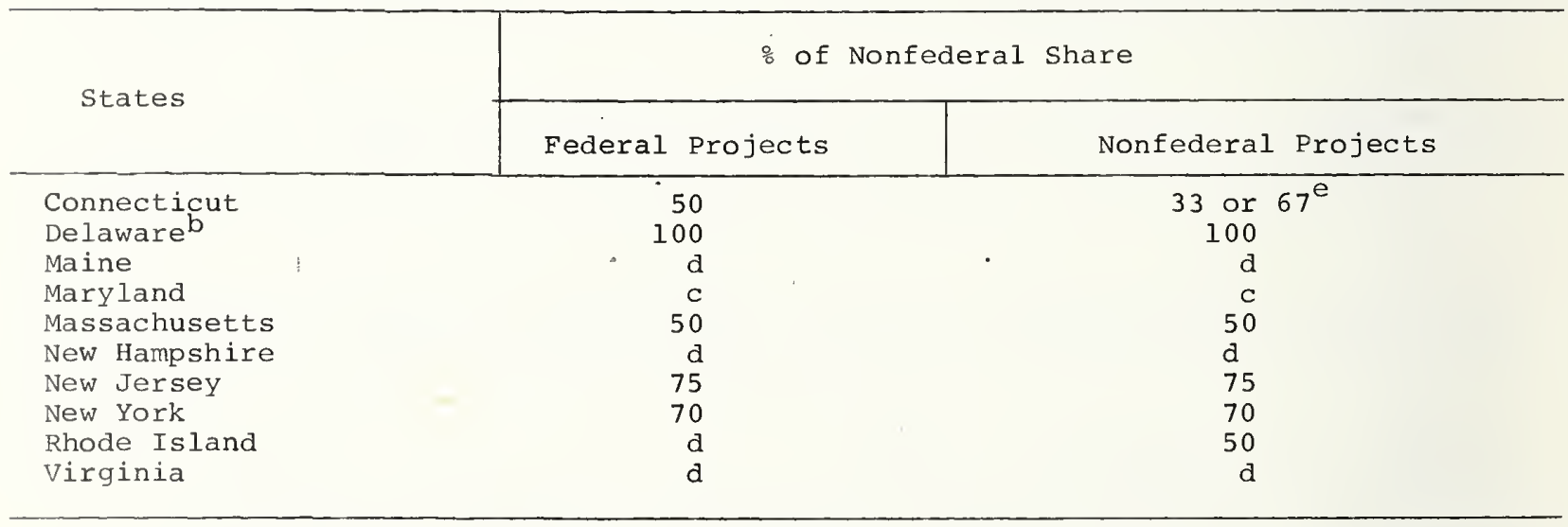

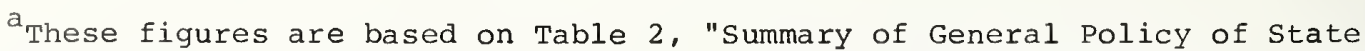
Participation in Shore Protection Projects," National Shoreline Study: Regional Inventory Report, North Atlantic Region, A part of the National Shoreline Study (Washington, D. C.; U.S. Army Corps of Engineers, 1971), Vol. 1, p. 103.

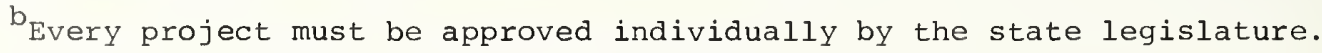

${ }^{\mathrm{C}}$ The state makes interest free loans to municipalities.

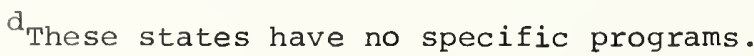

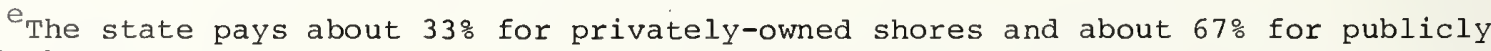
owned shores. 
BOOKS

Break, George F. Intergovernmental Fiscal Relations in the United States. Washington, D. C.: The Brookings Institution, 1967.

Marglin, Stephen A. "Objectives of Water-Resource Development: A General Statement." Design of Water Resource Systems. Edited by Maass et al. Cambridge: Harvard University Press, 1962. 17-87.

Regan, Mark. "Sharing Financial Responsibility of River Basin Development." Economics and Public Policy in Water Resources Development. Edited by Stephen C. Smith and Emery N. Castle. Ames: Iowa State University Press, 1961. 209-221.

Renshaw, Edward F. Toward Responsible Government: An Economic Appraisal of Federal Investment in Water Resources Programs. Chicago: Idyia Press, 1957.

White, Gilbert F. Human Adjustment to Floods: A Geographical Approach to Flood Problems in the U.S. University of Chicago, 1945.

\section{ART ICLES}

Adams, Dale W. and Rask, Norman. "Economics of Cost-Share Leases in Less-Developed Countries." American Journal of Agriculture Economics, L (November, 1968), 935-942.

Loughlin, James C. "A Flood Insurance Model for Sharing the Costs of Flood Protection." Water Resources Research, VII (April, 1971), 236-244.

Loughlin, James C. "Cost-Sharing for Federal Water Resource Programs with Emphasis on Flood Protection." Water Resources Research, VI (April, 1970), 366-382.

Marshall, Harold E. "Economic Efficiency Implications of Federal-Local Cost Sharing in Water Resource Development." Water Resources Research, VI (June, 1970), 673-682.

McGuire, Martin C. and Garn, Harvey A. "Problems in the Cooperative Allocation of Public Expenditures." Quarterly Journal of Economics. LXXXIII (February, 1969) 31-39.

Thomsen, Dietrick E. "As the Seashore Shifts." Science News, C1 (June 17, 1972), 396-397.

\section{PUBLIC DOCUMENTS}

\section{Congressional Documents}

U.S. Congress. House. Committee on Public Works. Projects Proposed for Inclusion in Omnibus River and Harbor and Flood Control Legislation--1972. Joint Hearings before the subcommittee on Rivers and Harbors and on Flood control and Internal Development, House of Representatives, 92d Cong., 2d sess., 1972.

U.S. Congress. Senate. Committee on Public Works. Omnibus Water Resources Authorizations--1972. Hearings before the subcommittee on Flood Control--Rivers and Harbors, Senate, 92d Cong., 2d sess., 1972.

U.S. Congress. Senate. Committee on Public Works. Omnibus Water Resources Authorizations--1970. Hearings before the subcommittee on Flood Control--Rivers and Harbors, Senate, 91st Cong., 2d sess., 1970.

U.S. Congress. Senate. Introduction of a Bill to Amend Cost Sharing for Hurricane Protection Projects. Congressional Record. 91st Cong., 2d sess., April $30,1970,56308-56310$.

U.S. Congress. Senate. Policies, Standards, and Procedures in the Formulation, Evaluation, and Review of Plans for Use and Development of Water and Related Land Resources, S. Doc. 97, 87th Cong., 2d sess., 1962 . 
U.S. Congress. Senate. Study of Federal Reimbursement Policy for work by states and other Non-Federal Entities on Authorized Water Resources Projects. S. Doc. 10,90 th Cong., lst sess., Feb, 23, 1967.

U.S. Water Resources Council. "Proposed Principles and Standards for Planning Water and Related Land Resources." Federal Register, XXXVI, No. 245, Dec. 21, 1971, 24144-24194.

Public Laws

Amendment in Flood Control Act of 1941. P.L. 84-99. 84th Cong. (June 28, 1955).

Disaster Relief Act. P.L. 91-606. 91st Cong. (Dec. 31, 1971).

Flood Control Act. P.L. 85-500. 85th Cong. (July 3, 1958).

Flood Control Act. P.L. 87-874. 87th Cong. (Oct. 23, 1962).

National Flood Insurance Act of 1968. P.L. 90-448. 90th Cong. (Aug. 1, 1968).

River and Harbor Act. P.L. 71-520. 71st Cong. (July 3, 1930).

River and Harbor Act. P.L. 79-727. 79th Cong. (Aug. 13, 1946).

River and Harbor Act. P.L. 88-172, 88th Cong. (Nov. 7, 1963).

\section{Executive Departmental Documents}

U.S. Bureau of the Budget. "Circular on Water Resources Projects." Budget Circular No. A-47. Washington, D. C.: 1952 .

U.S. Department of the Army. Corps of Engineers. Emergency Employment of Army and Other Resources. ER 500-1-1, January 4, $19 \overline{72 .}$

U.S. Department of the Army. Corps of Engineers. Federal Aid Toward Shore Restoration and Protection. ER 1120-2-110, March 1, 1965.

U.S. Department of the Army. Corps of Engineers. Federal Participation in Coastal Protection Projects. ER 1165-2-19, August 20, 1969.

U.S. Department of the Army. Corps of Engineers. National Shoreline Study: Regional Inventory Report, North Atlantic Region. Vol. 1. A Part of the National Shoreline Study. Washington, D.C.: U.S. Army Corps of Engineers, 1971.

U.S. Department of the Army. Corps of Engineers. Report on the National Shoreline Study. A Part of the National Shoreline Study. Washington, D. C.: U.S. Army Corps of Engineers, 1971.

U.S. Department of the Army. Corps of Engineers. Shore Management Guidelines, A Part of the National Shoreline Study. Washington, D. C.: U.S. Army Corps of Engineers, 1971.

U.S. Department of the Army. Corps of Engineers. Shore Protection Guidelines. A Part of the National Shoreline Study. washington, D. C.: U.S. Army Corps of Engineers, 1971.

U.S. Department of the Army. Corps of Engineers. Shore Protection Program. Washington, D. C.: U. S. Army Corps of Engineers, 1970 .

U.S. National Water Commission. Water Policies for the Future: Final Report to the President and to the Congress of the United States. Washington, D. C.: U. S. Government Printing office, 1973.

U.S. Subcommittee on Evaluation Standards. Proposed Practices for Economic Analysis of River Basin Projects, Report to the Inter-Agency Committee on water Resources. Washington, D. C.: rev. ed., 1958. 


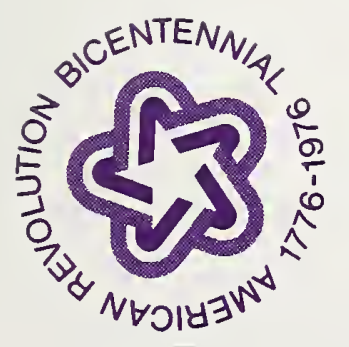


, 


$$
\text { . }
$$


NBS-114A (REV. 7-73)

\begin{tabular}{|c|c|c|c|}
\hline $\begin{array}{l}\text { U.S. DEPT. OF COMM. } \\
\text { BIBLIOGRAPHIC DATA } \\
\text { SHEET }\end{array}$ & 1. PUBLIL ATION OR REPORT NO. & $\begin{array}{l}\text { 2. Gov't Accession } \\
\text { No. }\end{array}$ & 3. Recipient's Accession No. \\
\hline \multirow{2}{*}{\multicolumn{3}{|c|}{$\begin{array}{l}\text { 4. TITLE AND SUBTITLE } \\
\text { Cost Sharing As An Incentive to Attain the Objectives of } \\
\text { Shoreline Protection }\end{array}$}} & $\begin{array}{l}\text { 5. Publication Date } \\
\text { December, } 1973\end{array}$ \\
\hline & & & 6. Performing Organization Code \\
\hline \multicolumn{3}{|c|}{$\begin{array}{l}\text { 7. AUTHOR(S) } \\
\text { Harold E. Marshall }\end{array}$} & $\begin{array}{l}\text { 8. Performing Organ. Report No. } \\
\text { NBSIR 73-294 }\end{array}$ \\
\hline \multirow{2}{*}{\multicolumn{3}{|c|}{$\begin{array}{l}\text { 9. PERFORMING ORGANIZATION NAME AND ADDRESS } \\
\text { NATIONAL BUREAU OF STANDARDS } \\
\text { DEPARTMENT OF COMMERCE } \\
\text { WASHINGTON, D.C. } 20234\end{array}$}} & 10. Project/Task/Work Unit No. \\
\hline & & & 11. Contract/Grant No. \\
\hline \multirow{2}{*}{\multicolumn{3}{|c|}{$\begin{array}{l}\text { 12. Sponsoring Organization Name and Complete Address (Street, City, State, ZIP) } \\
\text { The Center for Economic Studies } \\
\text { Institute for Water Resources } \\
\text { U.S. Army Corps of Engineers } \\
\text { Ft. Belvoir, Virginia } 22606\end{array}$}} & $\begin{array}{l}\text { 13. Type of Report \& Period } \\
\text { Covered } \\
\text { Final }\end{array}$ \\
\hline & & & 14. Sponsoring Agency Code \\
\hline
\end{tabular}

15. SUPPLEMENTARY NOTES

16. ABSTRACT (A 200-word or less factual summary of most significant information. If document includes a significant bibliography or literature survey, mention it here.)

The nation's shorelines are being eroded by high winds and waves. Nonfederal interests have traditionally received Federal help in the form of cost sharing for rotective structures. This study provides the Army Corps of Engineers with an evaluation of alternative cost-sharing rules for shoreline protection with respect to efficiency, equity, and administrative feasibility.

Existing cost-sharing rules are described for hurricane, beach erosion, and emergency protection. The present cost-sharing system appears to induce local interests to choose (1) costly techniques of protection, e.g., engineering rather than management techniques, and (2) overbuilt projects in terms of the efficient scale.

It is concluded that the Association Rule, which requires local beneficiaries of shoreline protection to share in all of the costs of a project purpose in the proportion that local benefits bear to national benefits at the margin, should be applied to all shoreline protection programs. All techniques of protection should be subject to the zame percentage cost-sharing rule. It is also concluded that all categories of project costs should have the same percentage cost share apply to them. Finally, Federal cost sharing might be used as an incentive to encourage local interests to comply with minimum land use requirements that would prevent shoreline damages.

17. KEY WORDS (six to twelve entries; alphabetical order; capitalize only the first letter of the first key word unless a proper name; separated by semicolons)

Beach erosion control; cost sharing; economics; efficiency; equity; incentives; shoreline protection

18. AVAILABILITY

For Official Distribution. Do Not Release to N'TIS

Order From Sup. of Doc., U.S. Government Printing Office Washington, D.C. 20402, SD Cat. No.C13

Order From National Technical Information Service (NTIS) Springfield, Virginia 22151
19. SECURITY CLASS (THIS REPURT)

UNCL ASSIF IED

20. SECURITY CLASS

(THIS PAGE)

UNCLASSIF IED
21. NO. OF PAGES

69

22. Price 
. 
Davis, Robert K. and Hanke, Steve H. Pricing and Efficiency in Water Resource Management. Report to the National Water Commission. NTIS No. PB-209-083. Springfield, Va.: National Technical Information Service, 1971.

Dolan, Robert and Godfrey, Paul. U.S. Department of the Interior, National Park Service, Dune Stabilization and Beach Erosion. Dune Stabilization Study. Natural Resource Report No. 5. Washington, D. C.: National Park Service, 1972.

Dolan, Robert. U.S. Department of the Interior. National Park Service. Beach Erosion and Beach Nourishment. Dune Stabilization study. Natural Resource Report No. 4. Washington, D. C.: National Park Service. 1972.

Hurlburt, Virgil I. Farm Rental Practices and Problems in the Midwest. Research Bulletin No. 416. Ames: Iowa State College Agriculture Experiment Station, 1954 .

Jagschitz, John A. and Bell, R. S. American Beachgrass, Agricultural Experiment Station Bulletin 383. Kingston: University of Rhode Island, 1966.

Jagschitz, John A. and Wakefield, Robert. How to Build and Save Beaches and Dunes. Marine Leaflet Series No. 4. Agricultural Experiment Station Bulletin 408. Kingston: University of Rhode Island, 1971.

The Malay Mail (Newspaper). "Swimming Lessions to Prepare for Floods." Kuala' Lumpar, Malaysia. November 10, 1972 .

Marshall, Harold E. and Broussalian, Vartkes L. Federal Cost Sharing Policies for Water Resources. National Bureau of Standards Report to the National Water Commission. NTIS No. PB-208-304. Springfield, Va.: National Technical Information Service, 1971.

Marshall, Harold E. "The Relationships Between Local Cost-Sharing and Efficient WaterResource Development." Unpublished Ph.D. dissertation, The George Washington University, 1969 .

Nixon, Richard. President of the United States. Letter to Honorable Rogers C. B. Morton, Chairman, Water Resources Council, 2120 L St., N.W., Washington, D.C. 20037 .

Rafuse, Robert W. and Sherman, Michael D. The Implications of the Net Fiscal Benefits Criterion for Cost Sharing in Flood Control Projects. Mathematica Report to the Corps of Engineers. IWR No. 71-12. Washington, D. C.: Institute for Water Resources, 1971 .

White, Gilbert F. Choice of Adjustment to Floods. Department of Geography Research Paper No. 39. Chicago: University of Chicago, 1964. 



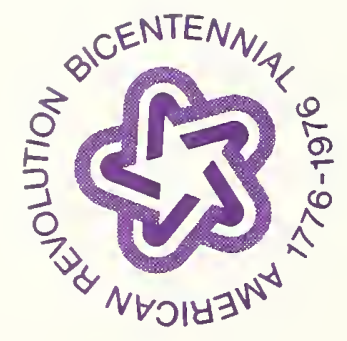

